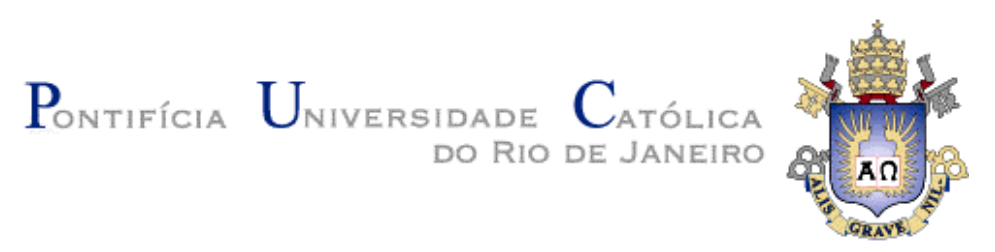

Denise Barreto da Silva

\title{
A gênese do conceito de inclusão na Educação Especial
}

\section{Dissertação de mestrado}

Dissertação apresentada como requisito parcial para obtenção do grau de Mestre pelo Programa de PósGraduação em Educação do Departamento de Educação do Centro de Teologia e Ciências Humanas da PUC-Rio.

Orientadora: Prof ${ }^{a}$. Ana Waleska Mendonça 


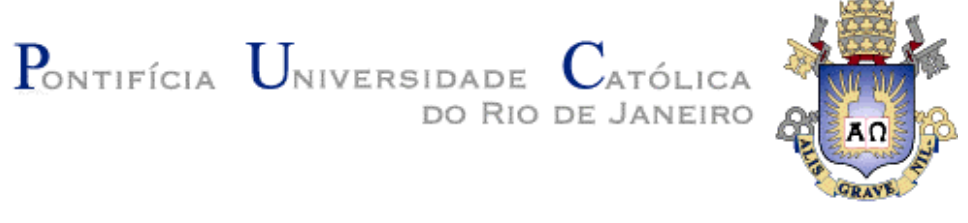

\title{
Denise Barreto da Silva
}

\section{A gênese do conceito de inclusão na educação especial}

Dissertação apresentada como requisito parcial para obtenção do grau de Mestre pelo Programa de PósGraduação em Educação do Departamento de Educação do Centro de Teologia e Ciências Humanas da PUC-Rio. Aprovada pela Comissão Examinadora abaixo assinada.

\author{
Profa. Ana Waleska Pollo Campos Mendonça \\ Orientadora \\ Departamento de Educação - PUC-Rio
}

Profa. Zena Winona Eisenberg

Departamento de Educação - PUC-Rio

Prof ${ }^{\text {a }}$ Rosana Glat

UERJ

Prof ${ }^{a}$. Denise Berruezo Portinari Coordenadora Setorial de Teologia e

Ciências Humanas - PUC-Rio

Rio de Janeiro, 05 de abril de 2013 
Todos os direitos reservados. É proibida a reprodução total ou parcial do trabalho sem a autorização da universidade, da autora e da orientadora.

\section{Denise Barreto da Silva}

É licenciada e bacharel em Pedagogia pela Universidade do Estado do Rio de Janeiro (2008) e especialista em Dificuldades de Aprendizagem pela mesma universidade (2011). É professora da educação especial da rede municipal de Mesquita e professora itinerante da educação especial na rede municipal de Nova Iguaçu.

Ficha Catalográfica

Silva, Denise Barreto da

"A gênese do conceito de inclusão na educação especial / Denise Barreto da Silva ; orientadora: Ana Waleska Pollo Campos Mendonça. -2013.

$103 \mathrm{ff} ; 30 \mathrm{~cm}$

Dissertação (mestrado) - Pontifícia Universidade Católica do Rio de Janeiro, Departamento de Educação, 2013. Inclui bibliografia

1. Educação - Teses. 2. Educação especial. 3. Integração. 4. Inclusão. I. Mendonça, Ana Waleska Pollo Campos. II. Pontifícia Universidade Católica do Rio de Janeiro. Departamento de Educação. III. Título.

CDD: 370 


\section{Agradecimentos}

A Deus por ter derramado suas bênçãos em minha vida durante cada momento.

À PUC-Rio, pelos auxílios concedidos, sem os quais este trabalho não poderia ter sido realizado.

Aos meus familiares, em especial à minha mãe Glória, ao meu pai Anselmo e ao meu irmão Flávio por terem se alegrado por cada conquista minha.

Aos amigos para todas as horas Ilzani Valeira dos Santos, Luís Paulo Cruz Borges e Renata do Nascimento de Souza, companheiros de reflexões.

Aos amigos e funcionários da Escola Municipal Professor Marcos Gil do Município de Mesquita.

Aos colegas da turma de Mestrado, em especial a Erisson Viana, pelo apoio, e aos colegas do grupo de pesquisa.

À Prof ${ }^{\mathrm{a}}$. Dr ${ }^{\mathrm{a}}$. Ediclea Mascarenhas por todo incentivo.

À minha orientadora, $\operatorname{Prof}^{\mathrm{a}}$. Dr ${ }^{\mathrm{a}}$. Ana Waleska Mendonça. 


\section{Resumo}

Silva, Denise; Mendonça, Ana Waleska. A gênese do conceito de inclusão na Educação Especial. Rio de Janeiro, 2013, 103p. Dissertação de Mestrado - Departamento de Educação, Pontifícia Universidade Católica do Rio de Janeiro.

Este estudo tem como objetivo compreender como se deu a passagem do paradigma da integração ao paradigma da inclusão, assinalando conexões entre as mudanças históricas evidenciadas no período compreendido entre as décadas de 1970 e 1990 com a educação especial. A pesquisa foi desenvolvida a partir de análise documental. Foram analisados documentos nacionais e internacionais que fazem referência aos direitos das pessoas com necessidades educacionais especiais. Além disso, construiu-se um balanço historiado do período da questão e foi mostrado como se deu o atendimento da pessoa com deficiência desde momentos anteriores até chegar ao presente, polemizando questões atuais como as políticas nacionais em vigor e ainda políticas regionais de atendimento aos alunos com necessidades educacionais especiais. Os conceitos de integração e inclusão foram analisados com embasamento nos estudos de Koselleck, pois o autor considera que conceitos são indicativos de algo que está para além da língua; são indicadores de transformações políticas e sociais de profundidade histórica. A pesquisa evidenciou mudanças ocorridas no atendimento dispensado às pessoas com deficiência nos Estados Unidos durante a crise do petróleo na década de 1970 e como estas modificações influenciaram e contribuíram para a hegemonia do paradigma da integração. Em relação ao paradigma da inclusão, evidencia-se sua hegemonia a partir da década de 1990, considerando que, com o processo de globalização, cada vez mais se faz necessário que uma parcela significativa da população seja consumidora o que é possibilitado pela participação ativa na comunidade de pessoas com necessidades educacionais especiais, proporcionada por uma educação inclusiva. Além disso, são analisados alguns documentos que norteiam a prática pedagógica na Fundação de Apoio à Escola Técnica da Secretaria de Estado de Ciência e Tecnologia do Governo do Estado do Rio de Janeiro, nas escolas dos municípios do Rio de Janeiro, Niterói, Petrópolis e Mesquita para refletir sobre a aplicabilidade do conceito de inclusão nas políticas locais. 


\section{Palavras-chave}

Educação Especial; Integração; Inclusão. 


\section{Abstract}

Silva, Denise; Mendonça, Ana Waleska (Advisor). The genesis of the concept of inclusion in special education. Rio de Janeiro, 2013, 103p. MSc. Dissertation - Departamento de Educação, Pontifícia Universidade Católica do Rio de Janeiro.

This work aims to understand how the transition between integration paradigm and the inclusion paradigm happened, ticking connections between the historic changes that occurred the 1970s until 1990 with the special education. The research was developed through documents analysis. National and international documents about rights of the people with special educational needs were analyzed. It was made a historical analyze about the time of the theme and it was showed how the treatment of the people with desabilities happened of the past until the present, problematizing current questions like the national policies and the locals policies of the treatment of the special educational needs students. The integration's concept and the inclusion's concept was analyzed using the Koselleck's studies, because the author believes that concepts indicate something that is beyond the language and concepts indicate social and political changes that are importants to the history. The research revealed changes that happened in the special education in the United States during the oil crisis in the 1970s and how these modifications influenced and contributed to the hegemony of the integration paradigm. The paper revealed that the inclusion paradigm became hegemonic from 1990s because is necessary to the globalization process that a significant part of the population is consumer. It is possible if people with special educational needs participate in the community actively what is proportionate in a inclusive education. Furthermore, some documents that guide the pedagogic practice in the Foundation to Supports the Technical Schools of the State Secretariat of Science and Technology for Government of Rio de Janeiro and in the cities of the Rio de Janeiro, Niterói, Petrópolis and Mesquita were analyzed to reflect about the application of the inclusion's concept in the local policies.

\section{Keywords}

Special Education; Integration; Inclusion. 


\section{Sumário}

1. Introdução 12

1.1. O tema 12

1. 2. A metodologia 14

$\begin{array}{ll}\text { 1. 3. Refletindo sobre paradigmas } & 17\end{array}$

1. 4. Integração e inclusão 21

2. A pessoa com deficiência: mito, abandono e ciência 25

2. 1. Mito e abandono 25

2. 2. A ciência e a pessoa com deficiência 27

2. 3. A situação da pessoa com deficiência no Brasil 32

3. A emergência e consolidação do paradigma da integração 38

3. 1. A Declaração Universal dos Direitos do Homem 38

3. 1. 1. A Declaração Universal de Direitos Humanos e a Educação 44 Especial

3. 2. Integração escolar e normalização 45

3. 2. 1. A integração nos Estados Unidos 48

3. 3. A Declaração dos Direitos das Pessoas Deficientes 52

3. 4. A Declaração de Sundeberg 54

3. 5. A difusão do paradigma da integração no Brasil 55

4. A emergência do paradigma da inclusão 66

4. 1. A Declaração de Jomtien 66

4. 2. A difusão do paradigma da inclusão 70 
4. 3. A inclusão e a Declaração de Salamanca 73

4. 4. A educação no Brasil em tempos de inclusão 79

4. 5. Analisando algumas políticas públicas locais 87

4. 5. 1. Faetec 87

4. 5. 2. Município do Rio de Janeiro 89

4. 5. 3. Município de Mesquita 90

4. 5. 4. Município de Niterói 91

4. 5. 5. Município de Petrópolis 92

5. Considerações Finais 93

Referências bibliográficas 96 


\section{Lista de abreviaturas e siglas}

APAE - Associação de Pais e Amigos dos Excepcionais

Cademe - Campanha Nacional de Educação e Reabilitação de

Deficientes Mentais

CEB - Câmara de Educação Básica

CENESP - Centro Nacional de Educação Especial

CESB - Campanha para a Educação do Surdo Brasileiro

CFE - Conselho Federal de Educação

CLT - Consolidação das Leis do Trabalho

CNE - Conselho Nacional de Educação

Cnec - Campanha Nacional de Educação de Cegos

DUDH - Declaração Universal dos Direitos do Homem

ECA - Estatuto da Criança e do Adolescente

Faetec - Fundação de Apoio à Escola Técnica

IBC - Instituto Benjamin Constant

IBGE - Instituto Brasileiro de Geografia e Estatística

IHA - Instituto Helena Antipoff

INES - Instituto Nacional de Educação de Surdos

LDB - Lei de Diretrizes e Bases

MEC - Ministério de Educação e Cultura

OMS - Organização Mundial de Saúde

ONU - Organização das Nações Unidas

PNAD - Pesquisa Nacional de Domicílios

PNSN - Pesquisa Nacional de Saúde e Nutrição

PNUD - Programa das Nações Unidas para o Desenvolvimento Humano

QI - Quoeficiente de inteligência

RBEP - Revista Brasileira de Estudos Pedagógicos

SE - Secretaria de Educação

SEESP - Secretaria de Educação Especial

SENEB - Secretaria Nacional de Ensino Básico

UNESCO - Organização das Nações Unidas para a Educação, Ciência e Cultura

UNICEF - Fundo das Nações Unidas para a Infância 
Passado

Instrumento inútil, incapaz de transmitir verdadeiramente um momento.

O passado é um ex-presente e o presente é, não foi e nem será. Viver um exato momento envolve sensações corpóreas e emocionais que jamais serão sentidas da mesma maneira.

Um fato que já existiu, nos permite criar qualquer tipo de fantasia. O passado sempre será para nós extremamente positivo ou negativo. Sempre será possível fantasiar sobre um tempo que não existe, diferente da realidade.

O passado marca a criação de várias sensações que nunca existiram. O tempo cronológico cria visões abstratas do que não existe mais, só existe visão concreta do presente. Portanto, uma sensação só é no presente, se passou, deixou de ser.

A história exemplifica a abstração do passado. Um acontecimento de um tempo anterior nunca é fielmente descrito porque quando ele deixa de ser presente, ele se torna abstrato e o que não é concreto, é indescritível. Na verdade, o passado nunca existiu, sempre será um presente perdido.

Denise Barreto da Silva 


\section{1. \\ Introdução}

\section{1.}

\section{O tema}

No que diz respeito ao campo de conhecimento da Educação Especial, destacam-se nas últimas décadas dois grandes paradigmas, surgidos em momentos históricos diferenciados: o paradigma de autonomia pessoal e integração e o paradigma da inclusão.

O paradigma de autonomia pessoal e integração surgiu em meados da década de 1970 nos Estados Unidos. Segundo este paradigma, a pessoa com deficiência deve se mobilizar para participar efetivamente da sociedade, sendo assim, predomina o ideário de que o problema não é a deficiência e sim a situação de dependência da pessoa com deficiência (SILVA \& FERNANDES, 2008). O paradigma da integração prevê que o sujeito deve ser alvo de mudanças e é baseado em três passos: avaliação, intervenção e encaminhamento ou reencaminhamento da pessoa com deficiência para a sociedade (OLIVEIRA \& REIS, 2004). Este paradigma tornou-se hegemônico após a criação de diversas instituições como escolas especiais, centros de reabilitação e oficinas de trabalho protegidas, sob cuidado, orientação e supervisão de um profissional especializado (CORRÊA, 2009).

Uma das críticas tecidas acerca desse modelo é a busca da normalização dos sujeitos em detrimento do reconhecimento das diferenças singulares (OLIVEIRA \& REIS, 2004). Além disso, durante os debates sobre integração, os contextos familiar, sociocultural e educacional não foram contemplados e, como são partes fundamentais do processo, o deficiente é quem deveria se adaptar (CORRÊA, 2009, p. 93).

Iniciaram-se, assim, movimentos para a supressão das barreiras físicas e sociais colocadas a esses sujeitos, o que desencadeou o surgimento de conceitos como equiparação de oportunidades e acessibilidade a todos (FERNANDES \& SILVA, 2007). Neste contexto, emerge o paradigma da inclusão que propaga que 
a sociedade deve se adaptar para que pessoas com deficiência participem da vida cotidiana independentemente de suas condições.

Corrêa (2009) destaca que as críticas ao paradigma da integração se acentuaram no início da década de 1990. Segundo tais críticas, o mesmo não proporcionaria uma mudança na estrutura da sociedade, considerando que a pessoa com deficiência que é alvo de mudanças. Além disso, ressalta que o principal marco da ascensão do paradigma da inclusão foi a Declaração de Salamanca (1994) que proclamava, inclusive, o direito de todos à educação; o respeito às características individuais, aos interesses, às capacidades, às necessidades e a indicação de que a escola regular pode ser o meio mais eficaz de combater a discriminação.

Em suma, os programas de integração e inclusão se referem a formas específicas de inserção do aluno com necessidades educacionais especiais em sala de aula da rede regular de ensino. Entretanto, a inclusão é incondicional e exige adaptações do sistema de ensino ao aluno, enquanto a inserção decorrente da integração exige que o aluno se adapte às condições que o sistema de ensino oferece (MANTOAN apud GODOY, 2002).

Considerando o debate que legitima a aplicabilidade do paradigma da inclusão a partir de parâmetros éticos, considero essencial refletir sobre os fenômenos que se relacionam de maneira indireta ou direta com as políticas e ações relacionadas à Educação Especial em si.

Jannuzzi (2004) destaca que as diretrizes que dão embasamento às práticas relacionadas ao campo de conhecimento da educação especial, pouco são vinculadas a ciências como sociologia e história.

De maneira alguma, pretendo nesta análise deslegitimar a discussão de caráter ético que fundamenta a adoção do paradigma da inclusão nas políticas e práticas educativas. Buscarei refletir sobre os fatores que influenciaram a transição entre o paradigma da integração e o paradigma da inclusão, analisando o não-dito dos documentos que norteiam as ações relacionadas a cada paradigma.

Logo, neste trabalho, as ações ou as práticas não serão destacadas, sendo o enfoque direcionado aos documentos oficiais e à discussão das ideias e valores referentes ao momento de transição, alteração na hegemonia dos paradigmas no campo de conhecimento da Educação Especial. 
Quais são os principais marcos históricos referentes ao período em que surgiram as primeiras iniciativas relacionadas ao paradigma da inclusão que podem ter relação com a transição entre os paradigmas citados? Buscou-se através das análises, entender como se deu a passagem de um paradigma a outro e que condições históricas propiciaram essa mudança.

O estudo é relevante, por se tratar de um campo de conhecimento relacionado a uma minoria, neste caso específico as pessoas com deficiência, que se encontram em situação de marginalização em uma sociedade que se entende como democrática. Outrossim, existe a necessidade de compreender os mecanismos que conduzem a modificações no cenário educacional.

Portanto, na pesquisa realizada, buscou-se investigar possíveis conexões entre os acontecimentos relevantes no cenário nacional e internacional do período em que ocorreu a transição entre os paradigmas e sua relação de causalidade e/ou influência no campo da Educação Especial.

Estabeleci os seguintes objetivos específicos:

- Contribuir para o conjunto de estudos historiográficos sobre a Educação Especial.

- Assinalar a conexão existente entre as mudanças históricas evidenciadas no período selecionado e a Educação Especial.

- Empreender um estudo sobre os aspectos inerentes a cada um dos paradigmas indicados e sua relação com as transformações no cenário educacional, no período compreendido entre as décadas de 1970 e 1990.

\section{2.}

\section{A metodologia}

Para confecção do estudo, foi utilizada metodologia de pesquisa documental. De acordo com Raupp e Beuren (s.d.), esta metodologia baseia-se em materiais que ainda não receberam um tratamento analítico ou que podem ser reelaborados conforme o objetivo de pesquisa. Cabe ressaltar que na pesquisa documental, o trabalho do pesquisador (a) requer uma análise mais cuidadosa, visto que os documentos não passaram antes por nenhum tratamento científico (OLIVEIRA apud SÁ-SILVA; ALMEIDA et al, 2009, p. 6). 
A utilização de documentos em pesquisa permite acrescentar a dimensão do tempo à compreensão do social. Além disso, a análise documental possibilita a compreensão dos processos de maturação ou de evolução de sujeitos, grupos, conhecimentos, conceitos, comportamentos, mentalidades, práticas, entre outros (SÁ-SILVA; ALMEIDA et al, 2009).

Faz-se necessário em uma pesquisa documental, conhecer a história do documento, buscando apreender sob que condições este foi produzido, quem escreveu e com que propósito. Igualmente, deve identificar-se a sua forma material e o conteúdo que aborda (RODRIGUES \& FRANÇA, 2010).

Documento é tudo o que é vestígio do passado, tudo o que serve de testemunho é considerado como documento ou 'fonte' (CELLARD apud SÁ-SILVA; ALMEIDA et al, 2009, p. 7). Barros (2010) atualmente assinala a tendência a utilizar o termo fonte para designar a documentação histórica de todos os tipos. Estes, os documentos, podem se tratar, além de textos escritos, também de documentos iconográficos, cinematográficos, objetos do cotidiano, elementos folclóricos ou qualquer tipo de testemunho registrado (SÁ-SILVA; ALMEIDA et al, 2009).

É importante que o documento seja compreendido no contexto em que foi produzido. As expressões contidas e as palavras contidas no documento estão repletas de significados que variam com o tempo e no espaço (RODRIGUES \& FRANÇA, 2010). A análise do documento permite ao pesquisador usá-lo cientificamente, com pleno conhecimento de causa. Cabe ressaltar que este, o documento, é um produto da sociedade que o fabricou segundo as relações de forças que aí detinham o poder (LE GOFF, 1984).

Le Goff (1984) afirma que o documento é resultado do esforço das sociedades históricas para impor ao futuro - voluntária ou involuntariamente - alguma imagem de si próprias. No limite, não existe um documento-verdade. Todo o documento é mentira (p. 103). Além disso, Rodrigues e França (2010) ressaltam que nenhum documento é neutro e que nem sempre os seus significados se mostram claros ao pesquisador.

Serão analisados documentos internacionais relacionados aos paradigmas da inclusão e da integração e esta análise será feita com influência dos pressupos- 
tos teórico-metodológicos da História Cultural ${ }^{1}$. Esta contempla temáticas como sexualidade, religiosidade, vida cotidiana, atitudes diante da morte e cultura material. A abordagem destas questões possibilita novas reflexões, como por exemplo, sobre o tempo e suas múltiplas dimensões (FONSECA, 2003).

De acordo com Duby (apud FALCON, 2006, p. 336), a história cultural tem como proposta observar no passado, em meio aos movimentos de conjunto de uma civilização, os mecanismos de produção dos objetos culturais. A utilização dos seus pressupostos se justifica, pois dentre os seus objetos destacam-se os fatores ideológicos, o papel do imaginário, do sistema de valores, das imagens que servem para explicar o mundo (FALCON, 2006).

Outrossim, a análise do documento deve expor elementos importantes em busca da elucidação da natureza do sentido e da ideologia que conectam o sujeito, produtor do discurso, ao tempo histórico do documento.

A análise documental deve levar em conta:

1. O Interdiscurso, entendido como a memória discursiva;

2. O Intradiscurso: o eixo da formulação atual do discurso;

3. O jogo dos sentidos: a constituição, a formulação e a historicidade;

4. A paráfrase (o retorno aos espaços do dizer) e a polissemia (o deslocamento, ruptura de processos de significação) (RODRIGUES \& FRANÇA, 2010, p. 66).

De acordo com Barros (2010), o objeto é recortado não propriamente em função de uma determinada realidade histórico-social concernente a uma delimitação espaço-temporal preestabelecida, contudo o recorte se dá precisamente em função de uma determinada série de fontes ou de materiais que é constituída pelo pesquisador. Logo, é a documentação que impõe um recorte de tempo, a partir dos seus próprios limites e das aberturas metodológicas que ela oferece. Neste caso específico, o recorte se refere ao período das décadas de 1970 e 1990, ao longo do qual os documentos internacionais sugerem significativas modificações no campo da Educação Especial.

Em compartilhamento com a perspectiva de Barros (2010), buscou-se construir um balanço historiado da questão, mostrando como ela vem sendo tra-

\footnotetext{
${ }^{1}$ A História Cultural, ao menos na sua vertente francesa, deriva da fundação da revista Annales onde seu fundadores, Marc Bloch e Lucien Febvre, propuseram uma "história total" que estivesse aberta às contribuições de diversos campos de conhecimento. Estes ofereceram uma recusa a uma história caracterizada por ser política e épica, caminhando em direção à história social, focada em diferentes dimensões da vida dos homens no tempo.
} 
tada a partir de momentos anteriores da historiografia ou da literatura existente até chegar ao presente, polemizando questões mais atuais.

No capítulo Introdução, justifica-se a importância de pesquisar a transição entre os paradigmas da integração e inclusão, evidenciando o problema, o recorte temporal, os objetivos e a metodologia. Além disso, são apresentadas definições dos conceitos de integração e inclusão na perspectiva de diversos autores.

O capítulo A pessoa com deficiência: mito, abandono e ciência traz informações sobre o atendimento dispensado à pessoa com deficiência em diferentes momentos da história, abordando inclusive a trajetória da educação especial no Brasil a partir do século XIX.

O terceiro capítulo, A emergência e consolidação do paradigma da integração, é iniciado com a análise da Declaração Universal dos Direitos do Homem, considerando que os princípios deste documento foram utilizados para justificar a propagação do paradigma da integração. São destacadas iniciativas relacionadas à emergência deste paradigma nos Estados Unidos e no Brasil. Além disso, a Declaração dos Direitos das Pessoas Deficientes e a Declaração de Sundeberg foram analisados, pois estes fazem referência ao conceito de integração.

O capítulo A emergência do paradigma da inclusão é iniciado com a análise da Declaração de Jomtien, pois os princípios presentes no documento foram utilizados como embasamento para a Declaração de Salamanca, documento considerado um marco histórico da propagação do paradigma da inclusão, também analisado neste capítulo. São citadas legislações brasileiras que indicam a adoção do paradigma da inclusão como hegemônico. Por fim, são apresentadas algumas políticas locais que refletem princípios referentes ao paradigma.

As Considerações finais sintetizam as inferências ocasionadas pela abordagem teórica, citando inclusive, textos legais abordados no texto. Além disso, trazem apontamentos que podem sugerir novas pesquisas.

\section{3.}

\section{Refletindo sobre paradigmas}

De acordo com Kuhn (1970), um paradigma é aquilo que os membros de uma comunidade partilham e, inversamente, uma comunidade científica consiste em homens que partilham um paradigma (p.219). Dessa forma, os paradigmas da integração e da inclusão, hegemônicos em momentos distintos, configuram mo- 
delos partilhados por sujeitos envolvidos com a educação especial. De maneira semelhante, os profissionais reconhecidos como detentores de um saber legítimo neste campo de conhecimento são aqueles que em suas práticas atenderam as mudanças decorrentes da transição entre um paradigma e outro.

Segundo Thompson (1995), alguns dos valores e crenças socialmente partilhados constituem os elementos da ideologia dominante que garante a adesão das pessoas à ordem social por estar difundida na sociedade. Os paradigmas da integração e da inclusão, hegemônicos em momentos distintos, são carregados de ideais relacionados à ideologia dominante, conforme será discutido no decorrer deste estudo.

Kuhn (1970) ressalta que uma teoria para ser aceita como paradigma, deve parecer melhor que suas competidoras, mesmo sem explicar todos os fatos com os quais pode ser confrontada. $\mathrm{O}$ poder que a teoria assume quando penetra no pensamento popular é tanto maior quanto mais coincide com as formas cotidianas de pensar. No campo de conhecimento da educação especial, o sujeito deficiente é uma construção, resultado dos saberes do médico, do psicólogo, do pedagogo. As narrativas destes profissionais constituem representações sociais, ou seja, transformam-se em conhecimentos partilhados que influenciam na construção de uma realidade comum a um segmento social (MARQUEZAN, 2009).

Um dos significados da palavra incluir é inserir num ou fazer parte de um grupo. A palavra integrar pode significar tornar-se parte de um conjunto ou de um grupo ou ainda adaptar-se, combinar-se ${ }^{2}$. São termos semanticamente muito parecidos e isto faz com que muitas vezes esses termos sejam utilizados indistintamente. Em compartilhamento com a perspectiva de Koselleck (1992), os conceitos integração e inclusão não são efetivos apenas como fenômenos linguísticos, mas são indicativos de algo que está para além da língua. A transição entre paradigmas não compreende tão somente um fenômeno de linguagem, mas está vinculada a fatos históricos únicos e para compreendê-los, faz-se necessário estabelecer relações múltiplas com outros espaços. A emergência do paradigma da inclusão, em substituição à hegemonia do paradigma da integração, afetou a estrutura do grupo que atua neste campo. Neste sentido, consequentemente houve uma re-

\footnotetext{
${ }^{2}$ As definições foram obtidas no endereço eletrônico http://www.priberam.pt/dlpo/default.aspx?pal=integra\%C3\%A7\%C3\%A3o no dia 6 de janeiro de 2012.
} 
definição do campo de estudos (KUHN, 1970). Como exemplo, a Declaração de Salamanca que em seu discurso faz referência ao conceito de necessidades educativas especiais que contribuiu para a ampliação da abrangência de atendimento da Educação Especial.

O paradigma da inclusão sugere um consenso estável no campo de conhecimento da educação especial por ser universalmente aceito. $\mathrm{O}$ conceito de inclusão foi construído a partir de uma reflexão teórica e é uma possível tradução linguística de uma história que está em curso no campo da educação especial. Todo conceito se articula a um certo contexto no qual também pode atuar, tornando-o compreensível. Neste contexto de referência, a inclusão se refere ao processo em que a excepcionalidade, ou seja, o desvio individual, recebe ofertas para manter-se em condições gerais de vida coletiva. Este conceito adquiriu um conteúdo alterado de maneira decisiva à medida que foi um indicativo de mudanças em toda a sociedade e, por conseguinte, seu significado só pode ser recuperado historicamente.

Segundo Koselleck (2006), teorias, conceitos e atitudes, programas ou formas de comportamento classificados como ideológicos se diferenciam das manifestações consideradas como erro, mentira ou preconceito.

Thompson (1995) afirma que fenômenos ideológicos são fenômenos simbólicos significativos desde que sirvam em circunstâncias sócio-históricas específicas, para estabelecer e sustentar relações de dominação.

Cabe ressaltar que integração e inclusão participam de um mesmo processo histórico; são paradigmas correlacionados e inseparáveis. De acordo com Koselleck (2006), não é possível compreender o valor de um termo como "conceito" sem incluir conceitos contrários ou paralelos, e ainda sem registrar a intercessão entre as duas expressões.

Os textos políticos referentes a qualquer dos paradigmas, integração ou inclusão, estão conectados a um dia e fatos específicos. Estas palavras são conceitos, por causa da totalidade de circunstâncias político-sociais e empíricas agregadas a elas nas quais elas são usadas. Os conceitos integração e inclusão são indicadores de transformações políticas e sociais de profundidade histórica no campo da educação (KOSELLECK, 2006).

Consideremos como exemplos de tais circunstâncias conferências internacionais e nacionais que são registradas em forma de documentos como manifestos 
e declarações que configuram fontes primárias e pressupõem uma única interpretação das perspectivas daqueles que participam da sua elaboração (KOSELLECK, 1992).

Nesse sentido, como exemplo cito a Declaração de Salamanca na condição de texto político, e os textos políticos compreendem prognósticos que estão associados à situação política. Isto significa a alteração de uma determinada situação, é um momento consciente de ação política. O prognóstico em si está relacionado a eventos, cujo ineditismo ele próprio libera (KOSELLECK, 2006).

A partir da leitura de Koselleck (2006), compreendo que documentos e fatos estão relacionados, visto que linguagem e história permanecem dependentes uma da outra, mas nunca chegam a coincidir inteiramente e, ainda, linguagem e fatos políticos e sociais aparecem de formas diferentes para os atores da história. Como exemplo, destaca-se a Declaração de Salamanca, relacionada ao paradigma da inclusão, que constitui um marco histórico referente a este paradigma. A história da educação especial no que diz respeito a ações, permaneceu dependente da linguagem expressada neste documento e em outros, contudo isto não significa que este processo foi concomitante.

Os documentos citados no decorrer deste estudo demonstram modificações nas concepções consideradas legítimas no campo de conhecimento da educação especial. Kuhn (1970) destaca que a transição sucessiva de um paradigma a outro, por meio de uma revolução, é o padrão usual do desenvolvimento da ciência amadurecida. Há algo que demonstre uma revolução neste campo de conhecimento?

Os documentos oficiais evidenciam a hegemonia de cada conceito. Segundo Koselleck (2006), todo conceito se prende a uma palavra, mas nem toda palavra é um conceito social e político.

Os conceitos se mantêm polissêmicos. Apesar dos conceitos estarem associados às palavras, são mais do que palavras. Uma palavra se torna um conceito se a totalidade das circunstâncias político-sociais e empíricas em que e para que essa palavra é usada, se agrega a ela (KOSELLECK, 2006).

Integração e inclusão são conceitos, pois significado e significante coincidem na mesma medida em que a multiplicidade da realidade e da experiência histórica se agrega à capacidade de plurissignificação dessas palavras, de forma que seus significados só possam ser conservados e compreendidos por meio dessas mesmas palavras. 
Nesse caso específico, a totalidade de circunstâncias político-sociais e empíricas que remetem às palavras integração e inclusão se agregam a estas, tornando-as conceitos. Por exemplo, a eliminação de barreiras arquitetônicas e comunicacionais de ambientes escolares é uma circunstância que remete ao paradigma da inclusão.

1. 4.

Integração e inclusão

Segundo Pereira (1980), a integração é componente do mainstreaming que no sistema público dos Estados Unidos significa educar, colocar os "excepcionais" na corrente da vida nos diversos níveis e aspectos, mobilizando o indivíduo quer seja ele "excepcional" ou não. Os elementos básicos que poderiam afetar a integração educacional apontados, estariam relacionados à integração temporal, integração instrucional e integração social. A integração temporal se refere à disponibilidade ou oportunidade para que o excepcional permaneça com seus companheiros normais e aos resultados esperados das ações institucionais e sociais. A integração instrucional é referente à disponibilidade de oportunidades e de condições de estímulos que o excepcional encontra no ambiente da classe regular que facilitem seu processo de ensino-aprendizagem. E a integração social se vincula ao relacionamento entre o excepcional e seus companheiros normais dentro do grupo.

Amaral (apud CORRÊA, 2009) afirma que integrar significa oferecer oportunidades iguais, apesar das diferenças. Oportunidades estas relacionadas ao acesso das pessoas portadoras de deficiência ao mundo das relações sociais, ao mundo escolar; ao mundo do trabalho; ao mundo da cultura, do esporte e do lazer.

Pereira (1980) define integração como um fenômeno complexo que vai muito além de colocar e manter excepcionais em classes regulares; é parte do atendimento que atinge todos os aspectos do processo educacional. Este conceito teria evoluído como resultado da influência de forças políticas, jurídicas, sociais, psicológicas e pedagógicas. A autora afirma que a normalização é o objetivo do processo.

Além disso, afirma que no programa de integração, o aluno avança dentro do programa prescrito, segundo sua capacidade individual, dentro de ambiente 
flexível, possibilitando sua adaptação sem criar obstáculos ao excepcional e sem dificultar o ciclo de aprendizagem dos demais alunos.

Sproviere (apud CORRÊA, 2009) destaca que o processo de integração é caracterizado por atitudes e medidas terapêuticas, pedagógicas, sociais, jurídicas e políticas que permitem ao indivíduo levar uma vida tão normal quanto possível. De acordo com Sassaki (2005), integração significa inserção da pessoa deficiente preparada para o convívio social.

A integração pouco exige da sociedade em relação à modificação de atitudes, de espaços, de objetos de práticas sociais. No modelo integrativo, a sociedade aceita receber a pessoa com deficiência desde que seja capaz de:

- moldar-se aos requisitos dos serviços especiais separados (classe especial, escola especial etc);

- acompanhar os procedimentos tradicionais (de trabalho, escolarização, convivência social etc);

- contornar os obstáculos existentes no meio físico (espaço urbano, edifícios, transportes etc);

- $\quad$ lidar com as atitudes discriminatórias da sociedade, resultantes de estereótipos, preconceitos e estigmas;

- desempenhar papéis sociais individuais (aluno, trabalhador, usuário, pai, mãe, consumidor etc.) com autonomia mas, não necessariamente, com independência (SASSAKI, 2005, p. 21).

Segundo Wolfensberger (apud SANCHES \& TEODORO, 2006), integração é o oposto de segregação e o processo consiste nas práticas e nas medidas que maximizam (potencializam) a participação de pessoas em atividades comuns da sua cultura.

Pereira (1980) afirma que à luz do princípio da normalização, o conceito de "excepcional", estático e permanente deu lugar a uma visão mais dinâmica e humanística do excepcional. A autora destaca que a partir deste princípio, a pessoa excepcional é reconhecida como sujeito de direitos e deveres iguais aos demais seres humanos e é necessário que lhe sejam oferecidas as mesmas condições de vida dos demais seres humanos.

Em relação à integração, Sassaki (2005) destaca que esta constitui um esforço unilateral da pessoa com deficiência e seus aliados, onde a pessoa com deficiência deve procurar tornar-se mais aceitável para a sociedade.

Conforme citado anteriormente, o paradigma da integração foi alvo de muitas críticas. Diante disso, na década de 1990, surge o paradigma alternativo da 
inclusão o que se pode perceber nos documentos oficiais nacionais e internacionais.

O sentido da integração pressupõe a ampliação da participação em situações comuns para grupos e indivíduos que se encontram segregados. O princípio da inclusão significa que nem toda pessoa com deficiência necessita de recursos educacionais especializados, devendo estar na escola comum em situação comum de ensino (GODOY, 2002).

Jannuzzi (2004) afirma que a inclusão enfatiza o ensino e a escola, assim como as formas e condições de aprendizagem em vez de focalizar a deficiência da pessoa. Não está baseada no pressuposto de que o aluno deve se ajustar a padrões de "normalidade" para aprender e aponta para a escola o desafio de ajustar-se para atender à diversidade de seus alunos.

Na perspectiva do paradigma da inclusão, a classificação dos diferentes tipos de deficiência começou a ser colocada em segundo plano na definição de alunos com necessidades educacionais especiais, ampliando assim o leque de alunos que deveriam receber algum tipo de suporte (GLAT \& FERNANDES, 2005).

De acordo com Sanches e Teodoro (2006), inclusão é a palavra que pretende definir igualdade, fraternidade, direitos humanos ou democracia. Sanchez (2005) considera que, antes de tudo, a educação inclusiva é uma questão de direitos humanos.

Sassaki (2005) afirma que a inclusão consiste em adequar os sistemas sociais gerais de maneira que sejam eliminados os fatores que excluíam certas pessoas do seu seio e mantinham afastadas aquelas que haviam sido excluídas. Para incluir todas as pessoas, a sociedade deve ser modificada a partir do entendimento de que ela é capaz de atender às necessidades de seus membros.

Considera-se que o movimento a favor da educação inclusiva pode oferecer a visão estrutural e cultural necessárias para iniciar a reconstrução da educação pública. De acordo com Sanchez (2005), o conceito de inclusão aborda as diferentes situações que levam à exclusão social e educativa de muitos alunos, fazendo referência não somente aos alunos com necessidades educacionais especiais, mas a todos os alunos das escolas.

A autora considera que este conceito pode ser considerado um agente de mudança conceitual, especificamente quando defende que não basta que os alunos com necessidades educacionais especiais estejam integrados às escolas comuns e 
que eles devem participar plenamente da vida escolar e social dessa comunidade escolar.

Diante disso, na inclusão social está implícita a participação no mercado de trabalho competitivo, sendo este um objetivo da inclusão. Logo, não podem ser considerados incluídos se não adquirirem as atitudes necessárias para participar na sociedade e no emprego e/ou até que as diferenças entre suas atitudes e a de seus iguais sejam consideradas valorosas (SANCHEZ, 2005).

Além disso, Sanchez (2005) afirma que, na integração, para que um aluno com necessidades educacionais especiais pudesse estar numa classe regular, faziase necessário que apresentasse "dificuldades médias ou comuns". Na perspectiva da inclusão, todos os alunos são membros de direito da classe regular, sejam quais forem suas características pessoais.

Em relação à transição da hegemonia de um paradigma ao outro, destaco que os momentos de duração, alteração e futuridade contidos numa situação política concreta são apreendidos por sua realização no nível linguístico. Diante disso, as situações sociais e respectivas alterações já são problematizadas na essência dessa realização linguística (KOSELLECK, 2006).

As definições apresentadas por cada autor aqui destacado demonstram que os conceitos de integração e inclusão não pressupõem um dualismo rigoroso. Apesar das respectivas diferenciações, não são conceitos antitéticos. A diferença fundamental está nas adaptações a serem realizadas: no paradigma da integração, o sujeito que se adapta ao meio e, no paradigma da inclusão, a sociedade busca artifícios para atender às peculiaridades das pessoas com necessidades educacionais especiais. Em suma, no campo de conhecimento da educação especial, o que difere estes conceitos é a forma de relação estabelecida com essas pessoas, o sistema escolar e a sociedade. 


\section{2.}

\section{A pessoa com deficiência: mito, abandono e ciência}

O percurso histórico do sujeito com deficiência se deu por via marginal. Marquezan (2009) destaca que as diferentes formas de relação caracterizadas nos paradigmas da negação ${ }^{3}$, da segregação ${ }^{4}$ e da integração evidenciam que as pessoas com deficiência nunca se enquadraram em um modelo de homem considerado adequado nos diferentes momentos de desenvolvimento histórico (MARQUEZAN, 2009). A perspectiva da pessoa com deficiência sofreu alterações paralelamente à evolução das necessidades do ser humano e em razão da própria organização das sociedades (CAMPOS \& MARTINS, 2008).

Em verdade, a dicotomia anormal versus normal produz uma concepção de desigualdade entre os sujeitos o que legitimou no decorrer da história a fragmentação de um grupo em relação ao outro (GARCIA \& ROCHA, 2008), conforme será analisado neste estudo.

\section{1.}

\section{Mito e abandono}

De acordo com Barby e Garrido (2008), os registros sobre o tratamento dispensado às pessoas com deficiência na Antiguidade revelam que muitas sociedades nômades tinham o hábito de abandonar seus membros mais frágeis para que estes não se tornassem um fardo para o grupo. A luta pela sobrevivência em um período onde só os mais fortes sobreviviam, pode ter contribuído para que estes grupos construíssem modelos de pessoas e corpos.

Na Idade Média, com a difusão do cristianismo na Europa, a igreja considera que a pessoa com deficiência possui alma, logo não pode ser eliminada ou abandonada sem atentar-se para os desígnios da divindade. O status da pessoa com deficiência é modificado, sendo assim ele deixa de ser coisa e passa a ser pessoa, dotada de alma e beneficiada pela redenção de Cristo. Pessoas com defici-

\footnotetext{
${ }^{3}$ Segundo Silva (2004), a negação é assim constituída a partir de uma segregação, onde os sujeitos que se "mostram" não são "vistos" ou respeitados nos seus direitos. Consequentemente, a negação molda a identidade e a auto-imagem desses indivíduos.

${ }^{4} \mathrm{Na}$ perspectiva do paradigma da segregação, o sujeito considerado desviante, neste caso específico a pessoa com deficiência, deveria ser segregado do convívio com os "normais".
} 
ência passaram a ser acolhidas caritativamente em conventos ou igrejas, onde ganhavam a sobrevivência, possivelmente em troca de pequenos serviços à instituição ou à pessoa benemérita que as abrigava (PESSOTTI, 1984).

Nesse período, as atitudes em relação à pessoa com deficiência eram ambivalentes; transitavam entre a caridade e o castigo. A pessoa com deficiência passou por um lado a receber assistência, mas, por outro, passou a receber castigo quando incorria em condutas imorais (CORRÊA, 2009).

A condição de deficiência também era vista a partir de um enfoque sobrenatural; produto de entidades malignas. Por conseguinte, esses indivíduos foram alvo de perseguições de católicos e luteranos (PESSOTI, 1984). Admitia-se que a pessoa com deficiência passasse por rituais de exorcismo com flagelação (CORREAA, 2009). Segundo Miranda (2003), o tratamento dispensado variava de acordo com as concepções de caridade ou castigo predominantes na comunidade em que a pessoa com deficiência estava inserida.

No fim da Idade Média, a partir do século XIV, diversas mudanças econômicas, sociais e políticas ocorridas na Europa afetaram profundamente a posição ocupada pela Igreja. Fatores como a urbanização da sociedade, renascimento comercial, crítica da burguesia à Igreja, surgimento da imprensa, das escolas laicas e das universidades contribuíram para a criação de um contexto histórico menos propício à imposição dos dogmas religiosos e à aplicação de torturas e castigos (BARBY \& GARRIDO, 2008).

De acordo com Marquezan (2009) as explicações sobrenaturais a respeito da anormalidade começaram a ser revisadas durante o Renascimento. A ciência moderna iniciou a produção de um corpo de conhecimentos sobre a natureza, a sociedade e o desenvolvimento e o comportamento humanos que possibilitou a ressignificação da relação com o anormal.

Entre os séculos XVII e XVIII, a sociedade europeia, buscando isentar o poder público e as famílias do dever de educar tais sujeitos, se viu na necessidade de criar instituições que exercessem tal tarefa (PESSOTI, 1984). Percebemos, então, o surgimento de uma cultura asilar a respeito da pessoa com deficiência que ainda tem influencia na sociedade atual.

Dessa maneira, vemos o surgimento de uma prática social destinada a pessoas com deficiência (FERNANDES \& SILVA, 2007). Esse paradigma corresponderia ao modelo tradicional que definia a pessoa com deficiência como alguém 
a ser assistido (SILVA \& FERNANDES, 2008). Cabe ressaltar que o paradigma de institucionalização ${ }^{5}$ foi o primeiro modelo formal que caracterizou a relação estabelecida entre a sociedade e a pessoa com deficiência (OLIVEIRA \& REIS, 2004).

\section{2.}

\section{A ciência e a pessoa com deficiência}

A partir do Renascimento, surgiram diferentes estudos sobre o homem com novas perspectivas ideológicas que se refletiram nos conceitos de deficiência, assim como nas intervenções sobre elas. Obras de caráter científico passaram a orientar os estudos a respeito das pessoas com deficiência (CAMPOS \& MARTINS, 2008).

No que diz respeito à deficiência mental (intelectual), a história aponta que, durante os séculos XVII e XVIII, teóricos passaram a adotar a utilização dos termos idiota, imbecil e débil mental para se referir a estas pessoas. Estes termos foram utilizados por profissionais até o início do século XX (MUNIZ, 2008).

O século XVIII foi um período marcado por um desenvolvimento socioeconômico relevante e pluralismo de ideias, com destaque para a Filosofia iluminista e toda a variedade e riqueza de desenvolvimento em diversos campos de conhecimento, desde a Economia, à Ciência, passando pela Pedagogia. Destaca-se neste período, inclusive, o aparecimento de deficientes ilustres (CAMPOS \& MARTINS, 2008).

Os médicos foram os primeiros especialistas que se ocuparam de casos de dificuldade de aprendizagem. As ciências médicas e biológicas, especialmente a psiquiatria, atingiram grande desenvolvimento no final do século XVIII e no século XIX. Desta época estão datadas as rígidas classificações dos "anormais" e os estudos da neurologia, neurofisiologia e neuropsiquiatria conduzidos em laboratórios anexos a hospícios. Os progressos da nosologia recomendavam a criação de pavilhões especiais para os "duros de cabeça" ou idiotas (PATTO, 1999). Segundo Pessotti (1984), na medida em que a autoridade do sábio, o médico, e não o rigor e a replicabilidade da metodologia de pesquisa é o critério de validade e fi-

\footnotetext{
${ }^{5} \mathrm{Na}$ perspectiva do paradigma da institucionalização, a pessoa considerada desviante, englobando neste sentido pessoas com deficiência, transtornos mentais entre outras características, deveria ser assistida por instituições como hospitais, asilos e manicômios.
} 
dedignidade, o enfoque da deficiência já não é necessariamente supersticioso ou metafísico, é naturalista, mas pré-científico e, por vezes pseudocientífico.

A partir de meados do século XIX na Europa e nas primeiras décadas do século XX no continente americano, começaram a surgir os primeiros ensaios sobre a aplicação da psicologia científica na solução de problemas sociais e educacionais. O saber médico visava desenvolver dispositivos de prevenção dos distúrbios mentais que pudessem ser amplamente difundidos para as modernas populações urbanas (CAMPOS, 2003). Neste contexto vale citar o Tratado das degenerescências de Morel (1857), carregado de conteúdo alarmista e eugenista. Segundo sua teoria, a deficiência mental poderia resultar de uma tendência inata de quem tivesse mãe epilética ou um avô preguiçoso ou dado ao vinho. Nessa conjuntura, a deficiência mental é considerada uma ameaça à segurança pública (PESSOTTI, 1984).

Uma das crenças fundamentais no século XIX era a de que o mundo da classe média estaria aberto a todos. Aqueles que não conseguiam cruzar seus umbrais demonstravam falta de inteligência pessoal, de força moral ou de energia e estavam automaticamente condenados por isso. Em uma outra hipótese, uma herança racial ou histórica os invalidaria eternamente (PATTO, 1999).

No âmbito da liberal-democracia, a principal preocupação da psicologia entre o final do século XIX e as quatro primeiras décadas do século XX era com a superdotação e com a subdotação intelectual. Os testes de inteligência favoreciam via de regra os mais ricos, reforçavam a impressão de que os mais capazes ocupavam os melhores lugares sociais (PATTO, 1999).

No início do século $\mathrm{XX}$, os estudos da área da psicologia científica sobre percepção e memória proliferavam e o exame dos limites das capacidades mentais atraía a atenção de diversos pesquisadores. As pesquisas partiam da capacidade "normal" para a busca dos desvios da norma (PESSOTTI, 1984).

Os estudiosos Alfred Binet e Theodore Simon, no início do século XX, construíram instrumentos de diagnóstico de crianças com dificuldades escolares e isto resultou nas escalas de medida do desenvolvimento da inteligência e o conceito de "idade mental" (CAMPOS, 2003). Com estas contribuições, o problema da deficiência mental deixou de ser propriedade da medicina e tornou-se atribuição das psicologia como questão teórica. Em relação à prática, passa dos asilos e hospícios para a escola especial ou comum (PESSOTTI, 1984). 
Em 1908, o teste Binet-Simon foi traduzido e aplicado em larga escala por Henry Herbert Goddard (1866-1957) nos Estados Unidos e divulgado como o grande instrumento de medida da inteligência humana. As chamadas deficiências mentais, na escala de Binet, eram divididas nas hierarquias débeis mentais, imbecis e idiotas ${ }^{6}$. Segundo Castro e Castro (2006), grande parte das intenções de Goddard poderia esta resumida na eliminação dos débeis mentais, em nome da ciência, através de seu isolamento e da não-permissão para sua reprodução ou pelo impedimento não só da entrada de débeis mentais no país, assim com etnias estrangeiras que poderiam colocar em risco o povo americano, entendido como branco, anglo-saxão e protestante. Essa perspectiva da deficiência conduz a uma modalidade de educação especial, separada da educação regular e consequentemente a um sistema educativo diferenciador (CAMPOS \& MARTINS, 2008).

A aproximação entre medicina e educação foi realizada principalmente por meio do movimento da higiene mental e da prática com instrumentos de diagnóstico psicológico, tais como os testes de nível mental (CAMPOS, 2003).

As primeiras produções teóricas sobre a pessoa com deficiência foram realizadas por médicos. Estes profissionais passaram a atentar para o campo da educação, provavelmente, em busca de respostas ao desafio apresentado pelos casos mais graves, resistentes ao tratamento exclusivamente terapêutico (JANNUZZI apud MARQUEZAN, 2009, p. 68). Os médicos executavam e prescreviam o atendimento educacional a ser implementado pelo professor com a pessoa com deficiência (MARQUEZAN, 2009).

À medida que as contradições do capital, ao longo do século XX, impuseram novas vigências, ampliou-se a margem daqueles considerados desviantes do modelo social. As transformações sociais impuseram a demanda por novas habilidades, entre elas a capacidade de ler, escrever e calcular em níveis básicos. Além disso, as políticas de atendimento voltadas para as pessoas com deficiência foram ampliadas, já que estes sujeitos foram considerados capazes de integrar a força de trabalho, de forma direta ou indireta através da liberação dos responsáveis por

\footnotetext{
${ }^{6}$ Débeis mentais seriam os indivíduos com idade mental entre 8 e 12 anos; imbecis aqueles com idade mental entre 3 e 7 anos e idiotas seriam aqueles com idade mental inferior a 3 anos (CASTRO \& CASTRO, 2006). O conceito de idade mental traduzia a estimativa de nível intelectual médio correspondente a uma determinada faixa etária.
} 
seus cuidados. Logo, a educação especial passou a ser considerada necessária (LANCILLOTTI, 2003).

Nos países industriais capitalistas da Europa e da América, a demanda social por escolas aumentou, consequentemente a expansão dos sistemas de ensino trouxe consigo alguns problemas: a necessidade de explicar as diferenças de rendimento da clientela escolar e de justificar o acesso desigual desta clientela aos graus mais avançados de escolaridade (PATTO, 1999).

As dificuldades de aprendizagem escolar foram explicadas a partir da articulação da vertente das ciências biológicas e da medicina do século XIX, carregada de pressupostos racistas e elitistas, e da vertente da psicologia e da pedagogia da passagem do século, mais atenta às influências ambientais e mais comprometida com os ideais liberais democráticos. Por conseguinte, o discurso sobre os problemas de aprendizagem escolar e da própria política educacional nos países capitalistas no decorrer de todo o século XX foi marcado por um caráter ambíguo (PATTO, 1999).

Patto (1999) destaca que no início do século XX as oportunidades de educação escolar das classes populares eram muito pequenas. A escola era pouco democratizada, freqüentada em grande parte pelas camadas de nível socioeconômico mais favorecido. Esta instituição oferecia parâmetro facilitador de exclusão social de seus alunos, englobando como pessoas com deficiência, principalmente mental/intelectual, muitas crianças que traziam manifestações de ambientes diferenciados e/ou eram submetidas a métodos e técnicas inadequados (JANNUZZI, 2004).

Durante os trinta primeiros anos do século XX, a avaliação dos "anormais escolares" se tornou praticamente sinônimo de avaliação intelectual. Os testes de quoeficiente de inteligência (QI) adquiriram um grande peso nas decisões dos educadores no que tange ao destino escolar de grandes contingentes de crianças que na Europa e na América conseguiam ter acesso á escola (PATTO, 1999). A palavra "normal" foi usada para designar todo e qualquer um que, pelos critérios de inteligência, atenção, memória, se parecesse diferente daqueles da sua idade. Anormal designava desenvolvimento físico, intelectual ou mental defeituoso, contrário às normas (MARQUEZAN, 2009). Os testes de inteligência contribuíram na produção de indivíduos definidos e possuidores de uma identidade a partir de um parâmetro (CASTRO \& CASTRO, 2006). 
Entre as décadas de 1930 e 1940, a luta de muitos por ascensão social nos Estados Unidos resultara em frustração e aumento de comportamentos chamados "anti-sociais". À escola, mais especificamente aos professores, cabia a função de destruir algumas ficções democráticas e levar os cidadãos à aceitação da "dura realidade dos fatos":

1) os homens não nascem iguais; 2) apenas um pequeno números de pessoas pode ser alocado nos níveis sociais e econômicos mais altos da sociedade - há lugar apenas para uns poucos o topo da pirâmide; 3) a ascensão econômica está decrescendo na sociedade norte-americana; 4) a ascensão social de alguns deve corresponder à solidariedade social de muito; somente assim a frustração e o ressentimento da maioria poderão ser evitados e transformados nas necessárias solidariedade e coesão sociais (PATTO, 1999. p. 71).

Nesse contexto, a primeira associação de pais de pessoas com deficiência, a New York State Cerebral Paralisy Association, foi fundada na década de 1940. A mobilização que se fez em torno dessa iniciativa tinha como objetivo, inclusive, estimular organizações governamentais a criar uma nova legislação que proporcionasse recursos para a pesquisa, treinamento profissional e tratamento (GODOY, 2002).

Para além disso, durante a década de 1950, pais de crianças com deficiência intelectual começaram a se organizar e fundaram a National Association for Retarded Children (NARC). A fundação da NARC inspirou a criação das Associações de Pais e Amigos dos Excepcionais (APAEs) no Brasil (GODOY, 2002).

A partir da década de 1950, a crença na incompetência das pessoas pobres foi generalizada na sociedade. Neste contexto, a escola tinha a função de redentora, redimindo os pobres, curando-os de suas deficiências psicológicas e culturais consideradas as responsáveis pelo lugar que ocupam na estrutura social (PATTO, 1999).

Através da teoria da economia da educação, durante as décadas de 1960 e 1970, a educação passou a ser vinculada diretamente ao setor produtivo. Segundo esta teoria, a escola "prepara", desenvolve o "capital humano", a "força do trabalho" a ser "investida no setor produtivo" (JANNUZZI, 2004). Durante este período, a crise do modelo de atendimento segregacionista desencadeou no processo de integração das pessoas com deficiência (CAMPOS \& MARTINS, 2008). 
O conceito de deficiência deixou de refletir uma definição generalizada na qual todo deficiente era considerado louco, oligofrênico e idiota para ter uma definição mais específica. A Organização Mundial da Saúde (OMS), em 1976, apresentou a diferença entre deficiência de incapacidade e desvantagem (handicap) (GODOY, 2002):

As deficiências são relativas a toda alteração do corpo ou da aparência física, de um órgão ou uma função qualquer seja a sua causa e significam perturbações ao nível do órgão;

As incapacidades refletem as conseqüências das deficiências em termos de desempenho e atividade funcional do indivíduo, e representam perturbações ao nível da própria pessoa, e, As desvantagens (handicaps) dizem respeito aos prejuízos que o indivíduo experimenta devido à sua deficiência e incapacidade, e refletem a adaptação do indivíduo e a interação dele com seu meio (OMS, 1989, p. 21).

Em verdade, a teoria da deficiência começou a ser abalada somente no século XX, influenciada pelo progresso de ciências como a psicologia, a biologia, a genética e a pedagogia. Iniciativas pedagógicas ousadas como o trabalho desenvolvido pela médica italiana Maria Montessori ${ }^{7}$, por exemplo, contribuíram para minimizar o processo de marginalização do processo cultural e educacional relacionado à pessoa com deficiência intelectual (PESSOTI, 1984).

\section{3.}

\section{A situação da pessoa com deficiência no Brasil}

Vejamos a questão da institucionalização dos considerados anormais no Brasil. Bazílio (2002) caracteriza a história do atendimento à infância no Brasil em três diferentes fases. Destaca que a primeira se estende do descobrimento até o início da década de 1920 e pode ser descrita pela filantropia e pelo assistencialismo. Neste caso, a criança é tida como objeto da caridade e não como sujeito de direitos.

A infância pobre oitocentista era marcada por uma diversidade de termos para fazer referência aos desviantes: enjeitados, ignorantes, infelizes da sorte... Em casos como estes, as Casas da Roda $^{8}$ (hospícios, hospitais ou asilos) eram

\footnotetext{
${ }^{7}$ A médica italiana Maria Montessori desenvolveu um programa de treinamento para crianças com deficiência intelectual nos internatos de Roma no início do século XX (CORRÊA, 2009).

${ }^{8}$ A Roda é um dispositivo de madeira de formato cilíndrico, com um dos lados vazados, posto em um eixo que produz movimento rotativo. Este dispositivo existia em instituições de caridade para que as crianças fossem ali deixadas.
} 
vistas como uma solução para os médicos-católicos. A hospicialização integrava um debate de fundo moral-religioso, incorporado pela ordem médica (GONDRA, 2004). Essa forma de assistência, a caridade, teve a atuação predominante da Igreja Católica, do descobrimento do Brasil até meados do século XIX. A educação dos "deserdados" estava centrada no aspecto moral e na salvação da alma (RAMOS, 2001).

A partir do século XIX, construiu-se a doutrina médico-higiênica. O discurso médico, ao se referir à infância pobre, fez emergir e legitimou instituições e práticas, traçando um destino quase inflexível: abrigo, cuidados básicos, instrução rudimentar e trabalho manual. Represálias a tais instituições existiam. A doutrina protestante concebia esses estabelecimentos como um incentivo ao "erro" (GONDRA, 2004).

No Brasil, no campo da educação especial no século XIX, destaca-se, no município do Rio de Janeiro, a criação do Instituto dos Meninos Cegos ${ }^{9}$ em 1854 e do Instituto de Surdos-mudos ${ }^{10}$ em 1857 por iniciativa do governo imperial. Cabe ressaltar que estas instituições não objetivavam atender pessoas com deficiência das classes menos abastadas. Segundo Aranha (2000), adotava-se o paradigma da institucionalização, representado pela adoção da instituição total como local para o trato e o ensino dessa população, considerando que estas instituições isentavam a população do incômodo de conviver com o improdutivo, assim como do pesar de cuidar dele.

De acordo com Miranda (2003), o atendimento na educação especial no século XIX se referiu principalmente às deficiências visual e auditiva, havendo iniciativas de atendimento a pessoas com deficiência física em menor quantidade. Em relação à deficiência mental/intelectual o número de ações foi praticamente nulo.

Marquezan (2009) afirma que a medicina esteve vinculada à educação do sujeito deficiente no Brasil. A presença médica se fazia efetiva na relação do médico atendendo a pessoa com deficiência, na função de direção de serviços ligados

\footnotetext{
${ }^{9}$ O Instituto dos Meninos Cegos passou a ser chamado de Instituto Benjamin Constant a partir do ano de 1891 em homenagem ao terceiro diretor da instituição.

${ }^{10}$ O Instituto de Surdos-Mudos recebeu a denominação de Instituto Nacional de Educação de Surdos em 1957.
} 
a seu atendimento, no exercício da docência direta com ele e indireta na formação de novos profissionais.

Em uma publicação intitulada Débeis mentais na escola pública e higiene escolar e pedagogia de 1917, o médico Vieira de Mello, chefe do Serviço Médico-Escolar de São Paulo, trazia orientações para os profissionais que trabalhavam com pessoas com deficiência, inclusive questões relacionadas à forma de seleção e classificação. A inteligência era definida como principal parâmetro para a classificação das crianças em supernormal ou precoce, subnormal ou tardio e normal. As crianças com deficiência compunham o grupo subnormal. Neste grupo, estariam os astêmicos, indiferentes, apáticos, instáveis, irrequietos, impulsivos, ciclotímicos ou que participam de uma e de outra categoria e alunos portadores de defeitos pedagógicos (MARQUEZAN, 2009).

Retomando Bazílio (2002), a segunda fase é caracterizada pelo vasto corpo jurídico/institucional que foi criado pelo Estado para esse atendimento à infância no Brasil e teve início na década de 1920 e durou até a década de 1980. As instituições públicas e privadas privilegiavam o internato como alternativa de atendimento. Nesta fase, criaram-se dois Códigos de Menores, os Juizados de Menores, o Serviço de Assistência ao Menor e a Fundação Nacional do Bem-Estar do Menor. Cabe ressaltar que estas iniciativas estavam relacionadas a um discurso sobre a infância de suposta proteção e zelo pelos bons costumes. Campos (2003) destaca que a partir da década de 1920 foram também implantados importantes serviços em psicologia sediados em instituições educacionais, com destaque para o Laboratório de Psicologia da Escola do Aperfeiçoamento de Professores de Minas Gerais, em 1928.

Cabe ressaltar que até 1930, não dispúnhamos de um sistema de educação popular; as oportunidades de educação escolar das classes subalternas continuavam muito pequenas.

Durante a década de 1920, as reformas educacionais planejadas, como a de Sampaio Dória em São Paulo (1920) e a de Anísio Teixeira na Bahia (1925), foram baseadas nos princípios do movimento educacional europeu e norte-americano iniciado no século anterior conhecido como movimento da Escola Nova. No que diz respeito ao fracasso escolar, a teoria escolanovista não localizava as causas das dificuldades de aprendizagem no aprendiz, mas nos métodos de ensino (PATTO, 1999, p. 84) 
O movimento escolanovista, sedimentado na Europa, chegou ao Brasil influenciado por Decroly e Montessori que haviam se dedicado à educação de pessoas com deficiência e pelo americano John Dewey. A Escola Nova tinha como ênfase o estudo das características individuais, a proposição de ensino adequado e especializado e a adoção de técnicas de diagnostico do nível de inteligência (MARQUEZAN, 2009).

A partir de 1930, em decorrência das solicitações da sociedade industrial, houve um aumento do número de escolas públicas em relação ao número de habitantes, logo estenderam-se as possibilidades de acesso à educação para parte da população economicamente menos favorecida (KASSAR, 1998). Os educadores envolvidos com a educação do sujeito deficiente começaram a empregar a expressão "ensino emendativo", cuja finalidade era suprir falhas decorrentes da anormalidade com o objetivo de adaptar o educando ao nível social dos normais (MARQUEZAN, 2009).

A psicologia começou a se configurar no país como uma prática de diagnóstico e tratamento de desvios psíquicos, passando a justificar o fracasso escolar ou tentar impedi-lo através de programas de psicologia preventiva baseados no diagnóstico precoce de distúrbios no desenvolvimento psicológico infantil (PATTO, 1999).

Em relação à legislação, a Constituição de 1946, no capítulo II, abordava a educação e a cultura, estabelecendo que o ensino primário fosse obrigatório e gratuito. No artigo 172, constava que cada sistema de ensino teria obrigatoriamente serviços de assistência educacional que assegurassem aos alunos necessitados condições de eficiência escolar (MARQUEZAN, 2009).

A partir de 1850 até 1950, foram criadas diversas instituições especializadas. De acordo com Marquezan (2009), nesse período, a educação das pessoas com deficiência foi realizada por 65 instituições de ensino, sendo 11 de ensino especializado para o atendimento de alunos com deficiência e 54 escolas de ensino comum que atendiam também alunos deficientes. Cabe ressaltar que 52 eram mantidas pelos governos estaduais e duas pelo governo federal; 11 pertenciam à iniciativa privada.

A esse respeito, partindo de dados citados por Corrêa (2009), elaboramos a tabela abaixo: 
Tabela 1 - Instituições de atendimento especializado do período de 1850 a 1950

\begin{tabular}{|l|l|l|}
\hline Escolas & Natureza & Manutenção \\
\hline 40 & Ensino Regular & $\begin{array}{l}\text { Federal (01) } \\
\text { Estadual (39) }\end{array}$ \\
\hline 14 & Ensino Regular & $\begin{array}{l}\text { Federal (01) } \\
\text { Estadual (09) } \\
\text { Particular (04) }\end{array}$ \\
\hline 03 & Especializada & $\begin{array}{l}\text { Estadual (01) } \\
\text { Particular (02) }\end{array}$ \\
\hline 08 & Especializada & $\begin{array}{l}\text { Estadual (03) } \\
\text { Particular (05) }\end{array}$ \\
\hline
\end{tabular}

Fonte: Corrêa (2009)

Kassar (1998) destaca que, entre as décadas de 1950 e 1960, houve grande mobilização social, com o surgimento e o fortalecimento de algumas organizações e de movimentos educativos. Em 1956, o presidente Kubitschek demonstrou julgar necessário a educação de pessoas com deficiência quando propôs a ampliação do ensino emendativo por parte do governo federal, dos estados e dos municípios e um levantamento de profissionais considerados acessíveis aos indivíduos de capacidade reduzida e o oferecimento de oportunidades de trabalho (MARQUEZAN, 2009). Em relação aos métodos de recuperação ou educação, a partir de 1959, passaram a ser aplicados princípios da análise experimental do comportamento $^{11}$ ao ensino de pessoas com deficiência (PESSOTTI, 1984).

O poder público demonstra, neste período, uma preocupação com os problemas de aprendizagem e com a educação especial propriamente dita o que fica demonstrado na Lei de Diretrizes e Bases de 1961 que será abordada neste trabalho posteriormente. Em 1963, o presidente João Goulart destinou recursos para que as escolas especializadas pudessem ampliar o atendimento aos "jovens carentes de caracteres especiais na educação" (MARQUEZAN, 2009).

No que diz respeito ao ponto de vista educacional, utilizou-se até o início da década de 1980 a expressão "aluno excepcional" para identificar a criança com deficiência por esta necessitar de condições excepcionais para o aprendizado. Em

\footnotetext{
${ }^{11}$ A análise experimental do comportamento é uma maneira de estudar o objeto da psicologia. Na ocasião de um trabalho de análise experimental, há um estudo intensivo do comportamento do indivíduo, emprego de meios eficazes para o controle do comportamento do sujeito e programação de estímulos e registro de eventos automáticos.
} 
1994, o Ministério de Educação e Cultura (MEC) apresentou o termo "com necessidades especiais"12 em detrimento de "alunos com distúrbios de aprendizagem" ou "aluno excepcional" (GODOY, 2002).

Destaca-se que a história do atendimento dispensado ao público considerado anormal, esteve vinculada à história do atendimento dispensado à parcela da população considerada carente. Consequentemente, supunha-se que ações relacionadas ao paradigma da integração poderiam minimizar o impacto das desigualdades econômicas.

${ }^{12}$ A utilização do termo "aluno com necessidades especiais" é um reflexo das discussões ocorridas na Conferência Mundial de Educação Especial que ocasionou a confecção da Declaração de Salamanca em 1994. 


\section{3. \\ A emergência e consolidação do paradigma da integração}

\section{1.}

\section{Declaração Universal dos Direitos do Homem}

Alguns autores destacam a Declaração Universal dos Direitos do Homem como um documento relevante para a história do atendimento da pessoa com deficiência (CORRÊA, 2009; ARANHA, 2004). Além disso, seus princípios são retomados na Declaração dos Direitos das Pessoas Deficientes (1975), momento de hegemonia do paradigma da integração, e na Declaração de Salamanca (1994), norteada pelo paradigma da inclusão. Diante disso, fez-se necessário realizar uma análise do documento, considerando que os seus princípios estão presentes nos demais documentos que propagam o paradigma da integração.

A Declaração Universal dos Direitos do Homem (DUDH) foi aprovada em 10 de dezembro de 1948 na Assembleia Geral das Organizações das Nações Unidas. Este documento é considerado base para a luta universal contra a opressão e a discriminação, defende a igualdade e a dignidade das pessoas e reconhece os direitos humanos e todas as liberdades fundamentais que devem ser aplicados a todos os cidadãos do planeta $^{13}$.

O documento foi selecionado por sua relevância, sendo um norteador de movimentos de definição de políticas públicas na maioria dos países signatários e é referente a um período de grandes modificações no cenário mundial, visto que este foi elaborado após o término da Segunda Guerra Mundial em maio de 1945 e da criação da Organização das Nações Unidas (ONU) em junho de 1945, em São Francisco, em pleno período da chamada "Guerra Fria" (COIMBRA; LOBO et al, 2008).

Vejamos o contexto em que o documento foi confeccionado já que este pode apontar a existência de objetivos para além da afirmação de princípios éticos; é possível discutir a existência de objetivos relacionados ao não-dito no texto. Segundo Bourdieu (1996), os agentes sociais não agem de maneira disparatada e

\footnotetext{
${ }^{13}$ Conforme informações obtidas no endereço eletrônico http://www.brasil.gov.br/sobre/cidadania/direitos-e-deveres-individuais/declaracao-universal-dosdireitos-humanos no dia 12 de novembro de 2011.
} 
podem, inclusive, ter condutas razoáveis sem serem racionais. De acordo com Chartier (1988), o leitor sempre está inscrito no texto e este atenta para a possibilidade de o pesquisador buscar o reconhecimento das estratégias através das quais autores tentaram impor uma ortodoxia do texto, ou seja, uma leitura direcionada.

No período pós-guerra em que o documento foi confeccionado e aprovado, cerca de 50 milhões de pessoas haviam morrido em combate, aproximadamente 6 milhões de judeus foram exterminados em campos de concentração nazistas e um número não calculado de pessoas mutiladas e deficientes retornavam a seus países de origem (CORRÊA, 2009). Em relação à população europeia, é estimado que cerca de 36,5 milhões de europeus morreram por causas relacionadas à guerra como massacres em campos de extermínio e campos de batalha, doenças, subnutrição e fome, fuzilamento e incineração de reféns, além de ataques às regiões que seriam ocupadas. Cerca de 19 milhões desse total equivaliam a civis não-combatentes (JUDT, 2008).

Segundo Cruickshank (1974), as guerras foram primariamente mutiladoras, não tanto mortíferas. Milhares perderam a vida, contudo milhares mais foram feridos e incapacitados. $\mathrm{O}$ autor destaca que os homens antes de sua experiência nas forças armadas tinham sido cidadãos em suas comunidades, em alguns casos líderes comunitários, professores, médicos, homens de negócios, operários e funcionários civis. Afirma que quando devolvidos a suas comunidades na condição de pessoas incapacitadas, pessoas próximas continuavam a percebê-los na perspectiva da normalidade e à luz de suas associações anteriores.

Na Europa, no período pós-guerra, o número de mulheres era superior ao número de homens. As mulheres tinham aprendido a sobreviver sem eles, pois devido às circunstâncias, havia uma predominância feminina. A população feminina, devido ao evento guerra, assumiu funções que até então eram de supremacia masculina. Na União Soviética, por exemplo, a economia rural passou a depender significativamente das mulheres (JUDT, 2008).

Em relação à infância europeia, nesse período o número de órfãos era elevado em diversos países. Havia muitas crianças, perdidas, mutiladas e desfiguradas. As doenças se multiplicavam em decorrência da privação de alimentos e ainda pelas condições desfavoráveis de higiene (JUDT, 2008).

Com o fim da guerra, as fronteiras permaneceram basicamente intactas e houve um grande deslocamento de pessoas entre as nações. A Europa estava 
constituída de Estados-nações muito mais etnicamente homogêneos (JUDT, 2008).

A DUDH é considerada um dos documentos que nortearam as conquistas em diversos campos, para as pessoas de maneira geral, inclusive para aquelas com deficiência que são população alvo da Educação Especial. Mazzota (1996), utilizando a definição de clima social como conjunto de crenças, valores, ideias, conhecimentos, meios materiais e políticos de uma sociedade em um dado momento histórico, destaca que, somente quando este apresentou condições favoráveis, houve sensibilização e foram propostas e organizadas medidas para o atendimento à pessoa com deficiência. Destaca-se o período pós-guerra por este ter sido um período de democratização em diversos países.

O documento é reconhecido como uma força moral que norteia boa parte das decisões tomadas na comunidade internacional. É considerado um texto de referência ética que estabelece os direitos de todos os seres humanos, independentemente de sua nacionalidade, cor, sexo, orientação religiosa e política (CORREAA, 2009). De acordo com Koselleck (2006), a palavra humanidade pode abranger a todos de maneira que ninguém seja excluído ou pode alcançar uma determinada qualidade intitulada humanitas $^{14}$ que corresponde ao sentimento de humanidade o que possibilita exclusões não contidas no sentido da palavra. Portanto, o uso da palavra se torna incerto.

$\mathrm{Na}$ declaração, são encontrados alguns termos que fazem referência ao conceito de humanidade: membros da família humana, pessoa humana, dignidade humana, personalidade humana. Estes termos tendem a fazer referência a formas diferentes de interpretação do conceito de humanidade. Os termos membro da família humana e pessoa humana denotam uma condição de humano que aparentemente abrange a todos os sujeitos, inclusive aqueles considerados desviantes. A referência que estes conceitos fazem à humanidade representa uma exigência tão

\footnotetext{
${ }^{14}$ Melo (2006) afirma que na história semântica do termo humanitas podem ser identificadas diferentes etapas. Num primeiro momento significava clemência, sinônimo de misericórdia, mansidão e filantropia. Numa segunda etapa, o termo adquiriu o sentido de condição humana, num duplo sentido: como estilo ou forma de vida superior à dos bárbaros e como perfeição da natureza humana, o que implicava uma radical oposição entre o homem e o animal, entre os homens e as coisas. Há ainda outro sentido, onde humanitas adquiria significação técnica de doctrina ou eruditio: um meio de transformar o rudis (tosco, rude) em eruditus (polido, culto, erudito).
} 
grande de universalidade que parece não permitir que homem algum seja excluído.

Os termos dignidade humana e personalidade humana fazem referência a uma humanidade como característica, diferente da barbárie e relacionada a sentimentos como misericórdia e clemência. A humanidade na qualidade de humanitas pode remeter a ações caritativas e ainda conferir ao sujeito desviante o status de humano.

No preâmbulo do documento, é dito que considera-se essencial que os direitos humanos sejam protegidos pelo Estado de direito para que o homem não seja compelido, em último recurso, à rebelião contra a tirania e a opressão e, é afirmado ainda, que é essencial promover relações amistosas entre os povos.

No artigo I, é afirmado que todas as pessoas nascem livres e iguais em liberdade e direito e ainda que todos são dotados de razão e consciência e devem agir em relação às outras pessoas com espírito de fraternidade. Diante da afirmação, é possível entender que todos os homens possuem fundamentalmente a mesma capacidade física e intelectual e que as diferenças não são significantes. Entretanto, os seres humanos só são iguais ou desiguais em relação a determinadas características que devem ser especificadas (BOBBIO, 2009).

No artigo II, é afirmado que todo ser humano tem capacidade de gozar os direitos e as liberdades citadas na declaração independentemente de sua condição. Será aqui discutido o conceito de igualdade, presente no documento, considerando que a dicotomia normal versus anormal produz uma concepção de desigualdade entre os sujeitos (GARCIA \& ROCHA, 2008).

Discutir o conceito de igualdade presente na Declaração Universal dos Direitos Humanos é essencial, considerando que os conceitos de integração e inclusão têm estreita ligação com ele, além disso, documentos relacionados a estes paradigmas se referem a este conceito.

A palavra igualdade pode ser definida como qualidade daquilo que é igual; uniformidade, identidade de condições entre os membros da mesma sociedade, ou ainda equidade, justiça ${ }^{15}$. De acordo com Bobbio (2009), o conceito de igualdade

\footnotetext{
${ }^{15}$ As definições foram obtidas no endereço eletrônico http://michaelis.uol.com.br/moderno/portugues/index.php?lingua=portuguesportugues\&palavra=igualdade no dia 24 de abril de 2012.
} 
só pode ser sustentado por regras que determinam como certos benefícios ou gravames serão distribuídos entre as pessoas.

O conceito de igualdade emergiu como fundamental também anteriormente, em um período em que ocorriam diversas reconstruções após um momento de colapso social. De maneira semelhante, durante a Revolução Francesa os ideais igualdade, liberdade e fraternidade adquiriram um grau de importância após um momento de grandes transformações políticas. Patto (1999) afirma que a palavra igualdade é chave na decifração da produção cultural que prepara a Revolução Francesa e a sucede. Além disso, ressalta que no pensamento liberal não se trata de preconizar uma sociedade na qual as desigualdades desaparecerão e sim de torná-las justificáveis sem colocar em xeque a tese da existência de igualdade de oportunidades na ordem social que substitui a sociedade de castas inevitavelmente injusta.

A Declaração de Direitos do Homem e do Cidadão foi aprovada durante a Revolução Francesa, em 1789. Este documento proclama a igualdade e a liberdade de todos cidadãos perante a lei. A Revolução Francesa foi definida por Jacob Burckhardt como o primeiro período de uma era revolucionária (KOSELLECK, 2006). De acordo com Caldeira (2009), a declaração demarcou o fim do antigo regime, destruído pela revolução.

Tanto a Declaração Universal dos Direitos do Homem e do Cidadão e a Declaração Universal dos Direitos do Homem são marcos de períodos nevrálgicos; de transformações, no caso da Revolução Francesa e de definição de interesses comuns entre os Estados a fim de promover ou garantir a observância das normas, objetos de negociações entre os signatários, no caso da elaboração da DUDH. Os documentos se apresentam como um testemunho escrito e por si só podem compor uma prova histórica (LE GOFF, 1984).

É possível inferir que em situações de conflito social, surge a necessidade de reafirmar princípios éticos, muitas vezes necessários para a sobrevivência. Por exemplo, considerar a igualdade como princípio ético, em regiões em que povos que haviam estado em conflito durante a Segunda Guerra Mundial coabitavam o mesmo espaço, era de extrema necessidade para que a população pudesse se restaurar.

Conforme afirmado anteriormente, como consequência da guerra havia milhares de pessoas mutiladas. No artigo VII, é afirmado que todos são iguais 
perante a lei. Neste momento da história, o deficiente era reconhecido como pessoa. É importante ressaltar que a dicotomia normal versus anormal produziu uma concepção de desigualdade entre os sujeitos o que legitimou a fragmentação de um grupo em relação ao outro (GARCIA \& ROCHA, 2008). Ainda que houvesse segregação entre normais e anormais, a DUDH afirmava uma igualdade que independia das condições em que os sujeitos se encontravam.

Apesar da afirmação e reafirmação de diversos direitos, Mbyata (1997) destaca que a declaração não impunha qualquer obrigação. Além disso, ressalta que muitos direitos foram afirmados de maneira imprecisa e nenhum mecanismo de controle tinha sido previsto.

Uma igualdade não atingida seria um privilégio político ${ }^{16}$ não conquistado? Entendendo aqui a situação de igualdade desta maneira, é importante citar Koselleck (2006) que afirma que privilégios políticos ainda por serem conquistados, foram formulados primeiro na linguagem para que pudessem ser conquistados e para que fosse possível dominá-los. Diante disso, a igualdade, na condição de utopia, fora proposta no documento para que assim fosse possível concretizála.

Em relação à educação, destaca-se o artigo XXVI, onde é afirmado que toda pessoa tem direito à instrução, que esta será gratuita ao menos nos graus elementares e fundamentais e que a instrução elementar será obrigatória. É assinalado que a instrução será orientada para o pleno desenvolvimento da personalidade humana e o fortalecimento do respeito dos direitos humanos e pelas liberdades fundamentais. Além disso, à instrução é dada a função de promover a tolerância, a compreensão e a amizade entre nações, grupos raciais ou religiosos, atuando como coadjuvante nas atividades das Nações Unidas em prol da paz.

Reconhecendo que todo sujeito é humano apesar de sua singularidade, a instrução se configura como uma maneira de tornar úteis as diferenças sejam elas econômicas, sociais, psicológicas ou biológicas, ajustando umas as outras. A norma ainda assim exerce poder dentro de um sistema de igualdade formal, ou

\footnotetext{
${ }^{16}$ O termo privilégio político, utilizado por Koselleck (2006), é referente a direitos inerentes aos cidadãos. $\mathrm{O}$ autor destaca que a formulação de privilégios políticos ainda por serem conquistados se deu inicialmente na linguagem e isto ocorreu a partir da Revolução Francesa que está relacionada com a Declaração dos Direitos do Homem e do cidadão.
} 
seja, ainda que exista algo que legitime a condição igualitária, o documento, o poder exercido pela norma está presente.

Por exemplo, o texto do documento afirma que todo ser humano tem capacidade de gozar os direitos e as liberdades discriminadas na declaração independentemente de sua condição. As condições citadas, raça, cor, sexo, língua, opinião pública ou de outra natureza, origem nacional ou social, riqueza e nascimento, são relacionadas historicamente com configurações de normalidade.

\section{1.1.}

\section{A Declaração Universal de Direitos Humanos e a Educação Especial}

Em relação ao atendimento à pessoa com deficiência, o paradigma da institucionalização permaneceu hegemônico até meados da década de 50 do século XX (SEESP/MEC, 2004). A década de 60 foi caracterizada por intenso movimento mundial de defesa dos direitos das minorias, associado a críticas a este paradigma, caracterizado pelo abandono, confinamento com ensino de trabalhos ou ainda hospicialização (PESSOTTI, 1987).

Durante os anos 60 e 70, grande parte dos países, embasados pela Declaração Universal dos Direitos Humanos, passou a buscar um novo modelo de atendimento à pessoa com deficiência, buscar a integração destes sujeitos (SEESP/MEC, 2004).

A partir da década de 80 , o mundo passou a experimentar transformações como avanços na Medicina, o desenvolvimento de novos conhecimentos na área da Educação e principalmente a criação da via eletrônica como meio de comunicação em tempo real. O desenvolvimento técnico-científico permitia a manutenção da vida e o maior desenvolvimento de pessoas que, em épocas anteriores, não

podiam sobreviver. Além disso, evidenciam-se a quebra das barreiras geográficas, na comunicação e no intercâmbio de idéias e de transações, ou seja, a globalização que acabou definindo novos rumos nas relações entre países e sociedades diferentes (SEESP/MEC, 1994).

A diversidade, nessa conjuntura, foi evidenciada como característica constituinte das diferentes sociedades e da população, em uma mesma sociedade. $\mathrm{Na}$ década de 90, também à luz da defesa dos direitos humanos, constatou-se que a diversidade enriquece e humaniza a sociedade, quando reconhecida, respeitada e atendida em suas peculiaridades. Surge a ideia de que a manutenção de segmentos 
populacionais minoritários em estado de segregação social, mesmo em processo de atenção educacional ou terapêutica, não era condizente com o respeito aos direitos de acesso e participação regular no espaço comum da vida em sociedade, como também não possibilitava que a sociedade aprendesse a administrar a convivência respeitosa e enriquecedora, com a diversidade de peculiaridades existentes entre os sujeitos (SEESP/MEC, 1994).

O conceito de direitos humanos no qual o documento acima referido está baseado, foi utilizado para justificar a hegemonia tanto do paradigma da integração, quanto da inclusão, em diferentes momentos. Segundo Koselleck (2006), este conceito possui uma generalidade concreta, o conceito de direitos humanos é transferível, aplicável em contextos diferentes.

Os autores do documento certamente pensaram nos leitores como sujeitos a um sentido único, a uma compreensão correta, a uma leitura autorizada. Porém, a leitura permanece como uma prática criadora, produtora de sentidos singulares, de significações que de maneira nenhuma estão reduzidos à intencionalidade dos autores dos textos (CHARTIER, 1988)

É de suma importância considerar que a igualdade, no discurso da declaração, é interpretada de maneiras diferentes de acordo com cada paradigma. Uma maneira de interpretar a igualdade, à luz do paradigma da integração, é que, numa situação igualitária, uma vez atendidas as necessidades mínimas de cada um, cada um dependerá exclusivamente de sua capacidade. Em contraposição, segundo o paradigma da inclusão, a igualdade é imposta, ao menos teoricamente, à sociedade e principalmente ao governo que tem o dever de satisfazer as necessidades de cada um, por mais desiguais que sejam em gênero e grau (BOBBIO, 2009).

\section{2.}

\section{Integração escolar e normalização}

O mundo considerado desenvolvido, após a Segunda Guerra Mundial até aproximadamente 1975, teve progresso significativo, com quase pleno emprego, alto nível salarial, boa proteção de seguridade social (saúde, educação, previdência social etc). Os países desenvolvidos detinham três quartos da produção social e grande parte da exportação (JANNUZZI, 2004).

As Grandes Guerras haviam resultado na diminuição da mão-de-obra, seja em função da perda de soldados ou em decorrência do grande número de mutila- 
dos. Consequentemente, surgiram programas de educação, saúde e treinamento, objetivando a reintegração desses homens à força de trabalho. A partir dessa reinserção, os movimentos sociais passaram a reclamar a integração com base em direitos humanos (LANCILLOTTI, 2003).

De acordo com Jannuzzi (2004), em relação à educação especial, foi principalmente após a Segunda Guerra Mundial que foram tomadas providências significativas. Neste contexto, há destaque para declarações de princípios como a Declaração Universal de Direitos Humanos e Declaração dos Direitos das Pessoas Mentalmente Retardadas que incluíam o direito à educação, treinamento, reabilitação e orientação que possibilitassem o desenvolvimento máximo da sua capacidade, o máximo de seu potencial e o direito à vida em família. $\mathrm{O}$ interesse em diversos países era justificado em prol do desenvolvimento, a fim de torná-los úteis à sociedade.

No cenário internacional, o progresso ocorrido no período pós-guerra permitiu melhoria das condições de vida inclusive da classe operária. A população feminina cada vez mais se inseria no mundo do trabalho. Isto facilitou a mudança da concepção de família, surgindo cada vez mais instituições para cuidar de enfermos, crianças, idosos, deficientes, mendigos (JANUZZI, 2004).

Omote (1999) sinaliza que o movimento atual em que se busca a inclusão total pode ser originário das medidas adotadas nos países escandinavos na década de 1950 o que resultou na proposta do princípio da normalização. Isto significava que o deficiente disporia de condições de vida o mais próximo possível das de pessoas ditas normais, consolidando práticas integracionistas como o mainstreaming ${ }^{17}$ nos Estados Unidos.

Mendes (2006) afirma que o contexto histórico da década de 1960 apontava um avanço científico representado tanto na comprovação das potencialidades educacionais das pessoas com deficiência quanto pelo criticismo científico direcionado aos serviços educacionais existentes. Neste período, ocorria o aumento na demanda por ensino especial, ocasionado pela incorporação da clientela que cada vez mais passou a ser afastada do ensino regular, causando o crescimento do mercado de emprego dos profissionais especializados e a consolidação

\footnotetext{
${ }^{17}$ De acordo com Omote (1999), o termo mainstreaming se refere à política integracionista que se tornou imperativa nas décadas de 1960 e 1970 que recomendava que alunos com deficiência fossem escolarizados num ambiente mais normalizador possível.
} 
da área, o que também ajudou na organização de políticas de grupos que passaram a demandar por mudanças.

Em verdade, a partir da década de 1960, considerou-se conveniente adotar a ideologia da integração pela economia que esta representaria para os cofres públicos. Os programas paralelos especializados, num contexto de crise econômica mundial, ocasionaram uma aglutinação de interesses de políticos, prestadores de serviços, pesquisadores, responsáveis e pessoas com deficiência com o objetivo de integrar estas pessoas nos serviços regulares da comunidade. Dessa maneira, foram estabelecidas as bases para o surgimento do princípio da normalização e integração que se tornou paradigma hegemônico basicamente a partir da década de 1970 (MENDES, 2006).

O princípio da normalização teve suas origens nos países escandinavos, precisamente na Dinamarca (PEREIRA, 1980) com Bank-Mikkelsen (1969) e Nirje (1969) que questionaram as práticas da instituições residenciais e das limitações que esse tipo de serviço pressupunha em termos de estilo de vida (MENDES, 2006). De acordo com Nirje $(1994)^{18}$, o princípio da normalização significa proporcionar ao sujeito com retardo mental padrões e condições em seu cotidiano próximos às normas e modelos da sociedade. Mikkelsen (apud PEREIRA, 1980) afirmava que o Novo Ato Legal, promulgado em 1959 naquele país, colocava como objetivo final de todo serviço de Educação Especial criar condições de vida para a pessoa retardada mental semelhantes, tanto quanto possível, às condições normais da sociedade em que vive.

Esse princípio foi amplamente divulgado na Europa e América do Norte. Houve, durante as décadas de 1960 e 1970, o uso generalizado do princípio para planejar os serviços destinados a pessoas com deficiência, ocasionando um movimento de desinstitucionalização e reinserção na comunidade (MENDES, 2006).

A Revista Brasileira de Estudos Pedagógicos (RBEP) em um número do ano de 1962, por exemplo, descreve o panorama da educação especial da Hungria naquele momento. Destaca-se que o ensino deveria preparar as crianças deficientes para o trabalho produtivo, de maneira que, quando terminassem a escolarização, pudessem levar uma "existência normal" e exercer uma atividade considerada adequada às suas aptidões. Além disso, buscava-se tornar o ensino especial mais

\footnotetext{
${ }^{18} \mathrm{O}$ artigo de Bengt Nirje foi publicado inicialmente em 1969.
} 
eficiente por métodos de correção e compensação em condições de remediar as consequências da deficiência.

Nesse ano, a Revista Brasileira de Estudos Pedagógicos (RBEP) também descreve ações direcionadas aos "problemas de deficiência na infância" na Alemanha. Neste país, as crianças que não podiam seguir o curso de uma escola primária tinham imediatamente a possibilidade de receber ensino especial. Buscavase solucionar o problema, dando maior importância às crianças do campo e pequenas cidades. As escolas teriam internato para receber crianças com problemas de visão, audição e linguagem, mas que não precisassem freqüentar estabelecimentos destinados a cegos, surdos e mudos.

Na Itália, a partir de 1970, foi implantado um programa de integração escolar. A Lei Nacional n. ${ }^{\circ} 118$ de 1970 determinou a educação compulsória de deficientes nas escolas da rede de ensino e o fechamento das escolas especiais. Porém, a medida gerou uma série de problemas, considerando que se inseriam indiscriminadamente todos os alunos, sem considerar as peculiaridades dos indivíduos, em sala de aula da rede regular de ensino (GODOY, 2002).

Barby e Garrido (2008) destacam como relevante a publicação do Informe Warnock, na Inglaterra em 1978. Esta publicação descrevia a situação dos alunos com deficiência naquele país e contribuiu para a popularização do termo necessidades educacionais especiais ${ }^{19}$. Tonini e Costas (2005) ressaltam que, na época, o informe não conseguiu modificar a concepção hegemônica a respeito da deficiência.

\section{2.1.}

\section{A integração nos Estados Unidos}

Nos Estados Unidos, durante a década de 1970, buscaram-se mudanças na economia interna que visavam estabilizar o país com a finalidade de evitar um desastre mundial. Segundo Marinho (2010), as mudanças políticas ocorridas na Ásia que causaram instabilidade na economia dos Estados Unidos, e, por conseguinte, a desestabilização na sua economia interna e um efeito negativo na economia de países subdesenvolvidos que estabeleciam relações comerciais com a

\footnotetext{
${ }^{19}$ Tonini e Costas (2005) consideram o termo necessidades educacionais especiais referente ao aluno que apresenta algum problema de aprendizagem ao longo da sua escolaridade que exige uma atenção mais específica e maiores recursos educacionais do que os necessários para seus pares.
} 
potência hegemônica capitalista, tiveram relação com o estabelecimento de políticas públicas destinadas a atender pessoas com deficiência.

O período, marcado pela Guerra Fria, foi caracterizado por diversas modificações na economia e na cultura, perpassadas por questões políticas: a disputa pelo poder e a influência hegemônica das duas potências, Estados Unidos e União Soviética, que lideravam o tabuleiro geopolítico mundial (MARINHO, 2010). Mendes (2006) identifica como fator influenciador para a mudança na filosofia de serviços nas décadas de 1960 e 1970, o reconhecimento do custo elevado dos programas segregados, no contexto da crise mundial do petróleo.

As políticas internas modificaram a realidade econômica do país, em meio a um momento de crise econômica. Em 1975, o Congresso americano aprovou a lei 94-142, Lei Educação para Todas as Crianças com Deficiência, que deixava estabelecido que todas as crianças com deficiência tinham direito à educação "livre e apropriada" (CORRÊA, 2009). Fearon (1968) discute sobre o que chama de uso inadequado dos fundos públicos, aplicados muito mais em serviços de reformatórios do que no emprego de melhores esforços na prevenção contra a delinquência infantil e na utilização adequada dos recursos da sociedade da época.

Além disso, essa lei estabelecia que os pais deveriam participar do processo educacional de seus filhos, que o plano de educação seria individualizado e dar-se-ia em um ambiente o menos restritivo possível (CORRÊA, 2009). Em relação à atuação da família, Plattor e Plattor (1968) afirmam que a assistência de pais de crianças excepcionais deveria resultar em fornecimento de suficiente discernimento, conhecimento e compreensão entre eles, para ajudar fundamentalmente não só a si próprios como a outros na mesma situação. Segundo estes autores, quando os pais sentem verdadeira simpatia pelos problemas que lhes são comuns, podem fornecer encorajamento e apoio que reforçam ao máximo os serviços especiais que o profissional pode oferecer. Cruickshank (1974) define os pais de crianças excepcionais, em geral, como um grupo bem informado em relação a problemas médicos, psicológicos e educacionais concernentes a seus filhos. Considera-os como uma força vital e importante na comunidade e que estão numa posição realística e podem ajudar no estabelecimento de bons programas de escolas públicas e na melhoria daqueles que já estão em funcionamento. Com o apoio de uma família instruída, o atendimento à criança com deficiência seria muito menos 
oneroso, considerando que estes responsáveis poderiam dar continuidade à assistência fornecida pelos profissionais.

No fim da década de 1960, já se atentava para a possibilidade de atender alunos chamados de excepcionais em instituições convencionais de ensino:

A América reconhece que a educação é uma necessidade vital para todas as crianças "excepcionais", e que, com o devido tratamento, compreensão, treinamento e disposições, até as crianças "excepcionais" podem tornar-se membros inteiramente produtivos da sociedade (ROUCEK, 1968, p.9, grifo meu)

À medida que a educação se tornava necessária para a subsistência do sistema dominante, o atendimento educacional foi sendo dado. Da mesma forma que a educação geral, a educação da pessoa com deficiência seguiu o modelo de organização e reprodução da sociedade. Conforme a organização escolar primária foi ampliada, foram tomadas algumas iniciativas para o atendimento escolar do sujeito com deficiência. A demanda pela alfabetização e pela qualificação para o processo de produção contemplava, inclusive, a educação da pessoa com deficiência. O paradigma da institucionalização não mais permaneceu hegemônico, por causa da economia dos cofres públicos e dos bolsos particulares, considerando que assim seriam evitados manicômios, asilos e penitenciárias, visto que essas pessoas seriam incorporadas ao mundo do trabalho (MARQUEZAN, 2009).

O trabalho se constitui na condição fundamentada que define e caracteriza o que é ser humano e é uma condição histórica (LANCILLOTTI, 2003). A humanidade, condição análoga à de ser sujeito de direitos e deveres, da pessoa com deficiência, é vinculada à possibilidade de educação e exercício de uma atividade considerada produtiva para a sociedade.

De acordo com Cruickshank (1974), o conceito de individualização do ensino, embasado nas diferenças individuais, é uma parte integrante da escola elementar, logo a informalidade da escola elementar propiciou a aceitação de crianças excepcionais. $\mathrm{O}$ autor considera que os professores de escola elementar são mais capazes de integrar a criança excepcional dentro do programa escolar.

Em relação à escola secundária, esse autor destaca que o número de crianças excepcionais neste segmento era muito pequeno. Cruickshank (1974) afirma que historicamente a educação secundária era caracterizada pela instrução de grupo, por um apelo à criança intelectualmente normal ou superior, por ser caracterizado como uma preparação ao college, pela departamentalização da ins- 
trução e por padrões comuns de excelência e de realização. Segundo ele o pessoal da escola secundária tem estado menos preocupado com o indivíduo e mais com a matéria de ensino (p. 105).

Os conhecimentos adquiridos durante a escola elementar eram suficientes para formar mão-de-obra para os postos de trabalho relacionados à produção: atividades não-relacionadas a um trabalho de cunho intelectual. Diante disso, cabe à escola a função de, ainda que o sujeito seja considerado desviante, fornecer instrução necessária para que a pessoa com deficiência se torne produtiva.

Cruickshank (1974) destaca que a educação de crianças excepcionais é um reflexo de ideais humanitários que são parte de uma sociedade democrática fundada numa herança de tradição cristã e judaica. Segundo o autor, o valor pessoal do indivíduo, sem consideração de suas capacidades ou incapacidades, é parte do núcleo sólido dos ensinamentos da igreja e da sinagoga (p. 49). Para Koselleck (2006), a interpretação de textos religiosos como a Bíblia, pode ser transformada em uma análise do comportamento daqueles que se servem destes textos para deles derivar uma justiça supramundana que os obriga e os capacita a agir no contexto em que estão inseridos de uma maneira especial.

Durante a década de 1970, segundo Cruickshank (1974), existia um grau de unanimidade entre pessoas que ele chamou de esclarecidas em relação à educação especial no que diz respeito à integração como algo visto como positivo. Ele afirma que isto era um reflexo de vários fatores da vida americana, um reflexo do conceito democrático, onde deveria ser proporcionada igualdade de oportunidades a cada um, independentemente de religião, raça ou posição social. De acordo com o autor, a democracia aceita a responsabilidade pela educação de todas as crianças.

Segundo Bobbio (2009), a democracia é compatível com doutrinas de diversos conteúdos ideológicos, nesse caso o conceito democrático é compatível com o adotado pelo Estado Liberal, ou seja, com o Estado que reconhece e garante alguns direitos fundamentais, como são os direitos de liberdade de pensamento, de religião, de reunião etc. 


\section{3.}

\section{A Declaração dos Direitos das Pessoas Deficientes}

Em relação à década de 1970, momento que o paradigma da integração se configurou como hegemônico fundamentalmente, faz-se ainda necessário mencionar a Declaração dos Direitos das Pessoas Deficientes, aprovada pela Assembleia Geral da Organização das Nações Unidas em dezembro de 1975. Este documento retoma princípios da Declaração Universal dos Direitos Humanos, dos Acordos Internacionais dos Direitos Humanos, da Declaração dos Direitos da Criança e da Declaração dos Direitos da Pessoa Mentalmente Retardada. É afirmado que as pessoas deficientes têm direitos relacionados ao respeito à dignidade da pessoa humana, à saúde, à educação e à reabilitação. No caso da Declaração dos Direitos das Pessoas Deficientes, são discutidas possibilidades não relacionadas à privação do convívio social para os anormais, neste caso específico a pessoa com deficiência.

Considerando ideais relacionados à igualdade e à liberdade pregados inclusive pela Declaração Universal de Direitos Humanos, documento cujos princípios foram retomados na elaboração da Declaração dos Direitos das Pessoas Deficientes, o indivíduo desviante detém o direito de existir.

De acordo com o documento, a Assembleia Geral da Organização das nações unidas reafirma sua fé nos direitos humanos, nas liberdades fundamentais e nos princípios de paz, de dignidade e valor da pessoa humana e de justiça social. Em relação ao conceito de liberdade como proteção dos direitos fundamentais, Bobbio (2009) afirma que nesta perspectiva uma sociedade pode ser considerada livre somente na medida em que se fundamenta nos princípios do laissez faire ${ }^{20}$. Uma pessoa que possui estes direitos legalmente determinados e esteja sujeita aos deveres correspondentes a eles é livre, embora possa ser não-livre no que concerne a outros aspectos e em relação a agentes que não sejam do Estado, por exemplo, por causa da exploração econômica ou da pressão social.

\footnotetext{
${ }^{20} \mathrm{O}$ termo laissez faire significa uma doutrina econômica que se opõe a qualquer regulação do governo, ou ainda que proponha uma interferência minimamente necessária para a livre iniciativa comercial. Esta informação foi obtida no endereço eletrônico http://www.thefreedictionary.com/laissez-faire no dia 6 de outubro de 2012.
} 
O conceito de direitos humanos permite uma classificação em direitos civis, políticos e sociais. Os direitos civis dizem respeito à personalidade do indivíduo (liberdade pessoal, de pensamento, de religião, de reunião e liberdade econômica), através da qual é possibilitado o arbítrio se isto não ferir o direito do outro. Os direitos políticos estão ligados à formação do Estado democrático representativo e permitem a participação dos cidadãos na determinação dos objetivos políticos do Estado. Os direitos sociais (direito ao trabalho, à assistência, ao estudo, à tutela da saúde, liberdade da miséria e do medo) contemplam as exigências da sociedade industrial e implicam, por seu lado, um comportamento ativo por parte do Estado ao garantir aos cidadãos uma situação de certeza (BOBBIO, 2009). No caso específico deste documento, ao abordar liberdades fundamentais e direitos humanos no que concerne a pessoas com deficiência, busca-se garantir que estes sujeitos tenham participação efetiva e produtiva na sociedade.

Em relação aos conceitos de direitos humanos e liberdade, é possível constatar que o significado lexical de cada termo tem um alcance que ultrapassa aquela singularidade que pode ser atribuída ao acontecimento histórico (KOSELLECK, 2006). Estes termos são recorrentes em diversos documentos internacionais oriundos de momentos diferenciados.

Um aspecto marcante pode ser relacionado a um trecho extraído do documento em análise que se refere à necessidade

... de prestar assistência às pessoas deficientes para que elas possam desenvolver suas habilidades nos mais variados campos de atividades e para promover portanto quanto possível, sua integração na vida normal (ONU, 1975).

Demonstra-se uma preocupação em fornecer subsídios para que o sujeito desenvolva atividades relacionadas a uma vida considerada normal. Na Declaração é afirmado que as pessoas deficientes têm direito a tratamento médico, psicológico e funcional, incluindo-se aí aparelhos protéticos e ortóticos, à reabilitação médica e social, educação, treinamento vocacional e reabilitação, assistência, aconselhamento, serviços de colocação e outros serviços que pudessem possibilitar o máximo desenvolvimento da capacidade e habilidades do sujeito e que acelerem o processo de sua integração social. Além disso, é destacado que pessoas deficientes têm direito à segurança econômica e social e a um nível de vida decente e, de acordo com suas capacidades, a obter e manter um emprego ou desenvolver atividades úteis, produtivas e remuneradas e a participar de sindicatos. 
$\mathrm{O}$ atendimento das pessoas com deficiência em programas de prevenção terciária $^{21}$ está relacionado na Declaração dos Direitos das Pessoas Deficientes à possibilidade de integração social que está vinculada ao acesso de direitos sociais como estudo e trabalho. Jacques (1998) afirma que, na vida adulta, a inserção no mundo concreto do trabalho aparece como uma sequência lógica de uma vida "adaptada" e "normal" e como atributo de valor em uma sociedade pautada pelo fator produtivo. Um emprego proporciona recompensa financeira e consequentemente possibilita que este sujeito modifique seu status social; se antes da inserção no mundo do trabalho a pessoa com deficiência é um sujeito a ser reabilitado, com o trabalho ele se torna um sujeito que vive normalmente. Nirje (1994) destaca que o trabalho possibilita que a pessoa com retardo mental seja vista de maneira diferente pela sociedade e que esta adquira autorespeito.

\section{4.}

\section{A Declaração de Sundeberg}

A Conferência Mundial sobre Ações e Estratégias para Educação, Prevenção e Integração realizada em Torremolinos na Espanha resultou na Declaração de Sundeberg promulgada em 7 de novembro de $1981^{22}$. A Declaração ressalta que toda pessoa com deficiência deve exercer seu direito fundamental de ter acesso à educação, ao treinamento, à cultura e à informação. Para assegurar a mais plena participação possível das pessoas com deficiência, os governos e as organizações nacionais e internacionais deveriam tomar medidas efetivas.

Declara-se que as pessoas com deficiência devem receber oportunidade de utilizar o máximo de seu potencial criativo, artístico e intelectual para benefício pessoal e para o melhoramento da comunidade. Dessa maneira, fornecer subsídios para que os sujeitos, através de suas capacidades e habilidades, possam garantir a própria subsistência e contribuir para o desenvolvimento econômico da sociedade.

No artigo 6, afirma-se que os programas educacionais, culturais e informacionais devem visar a integração das pessoas com deficiência. No artigo 8, é destacado que a participação da família na educação, no treinamento, na reabilitação

\footnotetext{
${ }^{21}$ Corrêa (2009) define prevenção terciária como ações que tenham como objetivo dar atendimento adequado à pessoa deficiente de forma a reduzir as consequências dos problemas gerados pela deficiência. Como exemplo, a autora cita programas de reabilitação, programas de educação especial e qualificação profissional.

${ }^{22}$ O ano de 1981 foi o Ano Internacional das Pessoas Deficientes.
} 
e no desenvolvimento de todas as pessoas com deficiência deve aumentar. O documento afirma que as famílias devem receber devida assistência para serem ajudadas a cumprir seu papel nesta área. Entretanto, o papel das famílias nesta conjuntura não é evidenciado.

Em relação a projetos referentes a desenvolvimento urbano, ambiente e assentamentos humanos, todos estes devem ser concebidos de modo que facilite a integração e a participação das pessoas com deficiência em atividades comunitárias, particularmente no campo da educação e da cultura. A ideia de facilitar o processo de integração não presume uma radicalidade em adaptar os ambientes.

\section{5.}

\section{A difusão do paradigma da integração no Brasil}

Nas últimas décadas do século XX, o atendimento educacional dispensado a pessoas com deficiência teve grandes modificações, justificado por um discurso que remetia à preocupação de humanização crescente dos serviços prestados. A expansão do atendimento educacional no Brasil foi motivada, inclusive, pelo ideal democrático de oportunidades iguais para todos que prevê que estes tenham acesso à escola, inclusive aqueles considerados expressivamente diferentes (OMOTE, 1999). Miranda (2004) destaca que a negligência e a omissão em relação à educação de pessoas com deficiência foi uma característica marcante durante as primeiras décadas do século XX. A produção teórica referente à deficiência intelectual(mental) esteve restrita aos meios acadêmicos, com escassez de oferta de atendimento educacional especializado.

Até então, apenas os países considerados desenvolvidos haviam criado um sistema educacional paralelo para pessoas com deficiências. De acordo com Mazzotta (1996), na política educacional brasileira, a inclusão da "educação de deficientes", da "educação dos excepcionais" ou da "educação especial” ocorreu somente no fim dos anos 1950 e início da década de 1960. Na década de 1950, ocorreu uma expansão das classes e escolas especiais na educação pública e de escolas especiais privadas e sem fins lucrativos (MIRANDA, 2004). Segundo Jannuzzi (2004), associações filantrópicas já vinham se organizando desde a década de 1930, incrementando-se a partir da década de 1950. Mendes (2006) afirma que a escassez de serviços e o descaso do poder público originaram movimentos comunitários que culminaram na implantação de redes de escolas 
especiais privadas filantrópicas para aqueles que não haviam sido inseridos na escola comum.

Marquezan (2009) afirma que o atendimento ao sujeito deficiente foi ampliado devido ao envolvimento da sociedade com essa problemática, ao desenvolvimento de organizações filantrópicas e de serviços ligados à saúde a à educação, aos movimentos internacionais no pós-guerra e ao movimento das pessoa com deficiência, citando como exemplo o movimento dos cegos a partir da década de 1954.

Além disso, de 1960 a 1980, consolidou-se no Brasil o modo de desenvolvimento urbano-industrial. Em relação à educação especial, ressaltou-se a importância da participação do deficiente no trabalho, na sua rentabilidade o que poderia aumentar seu poder e de sua família como consumidores (JANNUZZI, 2004).

Segundo Mazzota (1996), o período entre 1957 a 1993 foi caracterizado por iniciativas oficiais de âmbito nacional. A nível nacional, o atendimento aos considerados excepcionais foi assumido de maneira explícita com a criação de Campanhas voltadas para este fim. A primeira a ser instituída foi a Campanha para a Educação do Surdo Brasileiro (CESB), pelo decreto Federal n. ${ }^{\circ} 42.728$, de 3 de dezembro de 1957. Esta foi instalada no Instituto Nacional de Educação de Surdos (INES) no Rio de janeiro e tinha por "finalidade promover, por todos os meios a seu alcance, as medidas necessárias à educação e assistência, no mais amplo sentido, em todo o Território Nacional" ${ }^{23}$.

Nesse mesmo ano, um artigo de Kandel (1957), um educador norte-americano, demonstra a interferência maciça dos Estados Unidos na política educacional brasileira. O trabalho foi traduzido do International Review of Education especialmente para a Revista Brasileira de Estudos Pedagógicos (RBEP). Neste artigo, o autor defendia que os testes de habilidades e aptidões fossem aperfeiçoados para identificar o mais precocemente possível os "mais capazes", os "mais talentosos", os "grupos seletos". O autor afirmava que os dons do intelecto eram procedentes da vontade de Deus e o ser humano não poderia impedir na distribuição desigual, ou seja, quem não vence na escola ou na vida pertence ao contingente dos intelectualmente deserdados pela vontade divina (PATTO, 1999, p. 136).

\footnotetext{
${ }^{23}$ De acordo com Mazzota (1996) o trecho foi extraído do Decreto 42.728/57, Artigo $2^{\circ}$.
} 
Outrossim, Patto (1999) destaca que havia uma preocupação, no período referente às décadas de 1950 e 1960, de disciplinar e peneirar a clientela de origem popular a fim de estancar as pretensões educacionais das classes populares neste momento histórico marcado pelo populismo exacerbado.

Em 1958, foi criada a Campanha Nacional de Educação e Reabilitação dos Deficientes da Visão que funcionou no Instituto Benjamin Constant (IBC). Esta Campanha se desvinculou do IBC e passou a se chamar Campanha Nacional de Educação de Cegos (Cnec) que tinha como objetivo realizar treinamento e especialização de professores técnicos no campo da educação e reabilitação de deficientes visuais, além da assistência técnica e financeira aos serviços de educação especial e reabilitação (MARQUEZAN, 2009).

Em 1960, foi criada a Campanha Nacional de Educação e Reabilitação de Deficientes Mentais (Cademe) com o objetivo de promover a educação, treinamento, reabilitação e assistência educacional das crianças chamadas de retardadas e outros deficientes mentais de qualquer idade ou sexo. Os resultados não foram muito significativos, pois a estrutura social do país assegurava direitos e benefícios para poucos (MARQUEZAN, 2009).

Neste período, destaca-se, igualmente, a Lei de Diretrizes e Bases da Educação Nacional, Lei n. ${ }^{\circ}$ 4024/61, que reafirma o direito dos excepcionais à educação. Indica em seu Artigo 88 que para integrá-los na comunidade, sua educação deverá, dentro do possível, enquadrar-se no sistema geral de educação o que indica a presença do paradigma da integração (MARQUEZAN, 2009). Neste caso, a educação dos excepcionais deve ocorrer com a utilização dos mesmos serviços educacionais organizados para a população em geral (situação comum de ensino), podendo se realizar através de serviços educacionais especiais (situação especial de ensino) quando aquela não for possível (MAZZOTA, 1996). Cabe ressaltar que a Lei apresenta como preocupação principal a educação programada, sistematizada, o ensino na sua forma institucionalizada, ou seja a escolarização. Além disso, o texto da lei não apresenta indicação precisa de que a educação seria realizada mediante um currículo comum ou especial (MAZZOTA, 1986). Na ocasião estava em vigor a Constituição de 1946 que, em seu artigo 172, decretava que cada sistema de ensino teria obrigatoriamente serviços de assistência educacional que assegurassem aos alunos necessitados condições de eficiência escolar. A lei n. 4024/61 denominava estes alunos como excepcionais (MARQUEZAN, 2009), 
explicitava a posição oficial de preferência pelo ensino do deficiente na rede regular de ensino e deixava margem para uma possível isenção, no artigo 30, que desobriga a escolarização em casos de "doença ou anomalia grave da criança", assim como "comprovado estado de pobreza do pai ou responsável" (JANNUZZI, 2004). Aqueles que não possuíam algum tipo de perspectiva de inserção no mundo do trabalho eram isentos da obrigatoriedade escolar, aqueles que não poderiam ser mão-de-obra produtiva.

Durante um Simpósio de Educação Especial realizado em Brasília em 1962, conforme informação obtida na Revista Brasileira de Estudos Pedagógicos (RBEP), lembrou-se que excepcionais seriam elementos da coletividade e seriam tão dignos de consideração como a maioria dos cidadãos normais. Além disso, destacou-se que a educação dos excepcionais deveria ser realizada em classes comuns quando isto fosse possível.

Em um exemplar da RBEP de 1963, destacou-se que a lei orgânica do Estado da Bahia tratava no capítulo V da educação dos excepcionais. Uma das orientações dizia que, no que fosse possível, a educação dos excepcionais deveria se enquadrar no sistema geral da educação com a finalidade de integrá-los na comunidade.

A Constituição de 24/01/1967, com a redação dada pela Emenda Constitucional n. ${ }^{\circ}$ 1, de 17/10/1969, e o Artigo Único resultante da Emenda Constitucional n. ${ }^{\circ} 12$, de 17/10/1978, estão estreitamente ligados aos dispositivos de atendimento às pessoas com deficiência. No Título IV, Da Família, da Educação e da cultura, os artigos 175, 176 e 177 definem, respectivamente, que lei especial disporá sobre a educação dos excepcionais; que a educação é direito de todos e dever do Estado, devendo ser dada no lar e a escola; e que, obrigatoriamente, cada sistema de ensino terá serviços de assistência educacional que assegurem, aos alunos necessitados, condições de eficiência escolar (MAZZOTTA, 1996).

No Título III, Da Ordem Econômica e Social, o Artigo Único, incluído entre os artigos 165 e 166, assegura aos deficientes a melhoria de sua condição social e econômica, mediante a educação especial e gratuita; a assistência, reabilitação e reinserção na vida econômica e social do País, a proibição de discriminação, inclusive quanto à admissão ao trabalho ou ao serviço público e a salários e a possibilidade de acesso a edifícios e logradouros públicos (MAZZOTTA, 1996). Uma vez que pessoas com deficiência fossem inseridas de maneira ativa na vida 
social e econômica do país em condições similares a de pessoas ditas normais, poderiam contribuir na arrecadação de impostos significativamente, adquirir bens de consumo, entre outros fatores. Nesta perspectiva, contempla-se o princípio da normalização em que se reconhece que o sujeito antes de ser excepcional ou diferente, é pessoa com direitos e deveres iguais aos demais seres humanos, necessitando que lhe sejam oferecidas as mesmas condições de vida (PEREIRA, 1980).

De acordo com Jannuzzi (1997), no que diz respeito à Educação Especial, a década de 1970 foi marcada por várias iniciativas governamentais. Em 1972, foi criado o Grupo Tarefa de Educação Especial, cuja atribuição era a elaboração da primeira proposta de estruturação da educação especial no Brasil (RODRIGUES, 2010).

Mazzota (1986) destaca como relevantes as normas e diretrizes expressas nos Pareceres do Conselho Federal de Educação (CFE) n. ${ }^{\circ}$ 848/72 e n. ${ }^{\circ}$ 1682/74. Aquele aponta a idade mental como critério para a extensão do ensino gratuito até o limite real de educabilidade de cada aluno. Este define os alunos deficientes mentais educáveis, fornece alguns indicadores para o acompanhamento e avaliação do desempenho de tais alunos. Além disso, sugere alguns objetivos do atendimento especial, o número máximo de vinte alunos por turma e salienta que um currículo especializado, material e equipamento são necessários para esses alunos.

A Resolução da Secretaria de Educação (SE) n. ${ }^{\circ}$ 73/78 demonstra a preocupação com a integração do aluno "excepcional" nas atividades regulares da escola, em coerência com o artigo 88 da Lei 4024/61. São definidos, inclusive, os tipos de serviços e auxílios especiais que podem ser organizados na própria escola comum, de forma a atender os alunos excepcionais, proporcionando-lhes atendimento educacional especializado na escola comum (MAZZOTTA, 1986).

Para gerir as ações do Grupo Tarefa de Educação Especial foi criado o Centro Nacional de Educação Especial (CENESP), em 1973 (RODRIGUES, 2010). O CENESP elaborou planos nacionais de Educação Especial de 1975/77 e 1977/79 o que assegurou a existência de um espaço de atuação governamental. O conjunto de diretrizes elaborado possibilitou oficialmente uma separação entre a educação especial e o sistema de ensino regular. Consequentemente, acentuaramse as diferenças relacionadas a essa modalidade de ensino, logo houve a possibilidade de reconhecimento da especificidade dos profissionais, dos alunos, dos estabelecimentos e dos recursos disponibilizados (JANNUZZI, 1997). O atendimento 
educacional como competência do Ministério da Educação e Cultura (MEC) através do CENESP, cuja ação era integrada com outros órgãos do setor da educação, conforme o artigo 3 da Portaria Interministerial n. ${ }^{\circ} 186$ que regulamenta o atendimento educacional, é caracterizado como seguidor de uma linha preventiva e corretiva (MAZZOTTA, 1996).

O Centro Nacional de Educação Especial (CENESP) surgiu na época do "milagre econômico" período que não contemplou a maioria da população e aumentou a diferenciação entre o país e o mundo considerado desenvolvido (JANNUZZI, 2004). O "milagre" estava baseado numa situação internacional favorável e na tomada de empréstimos internacionais. A crise do petróleo causou o aumento do seu preço no mercado internacional e isto impactou a economia brasileira: a inflação subiu significativamente e houve uma elevação da dívida externa (VELOSO; VILLELA et al, 2008).

Patto (1999) descreve algumas informações publicadas em um número especial da Revista de Estudos Pedagógicos de 1972, onde a "teoria da carência cultural" passava a explicar a desigualdade pelas diferenças de ambiente cultural em que as crianças das chamadas classes "baixa" e "média" se desenvolviam. Segundo esta teoria, a pobreza ambiental produz deficiências no desenvolvimento psicológico infantil que seriam a causa de suas dificuldades de aprendizagem e de adaptação escolar. Neste número especial, a criança excepcional era considerada sinônimo de criança carente.

Nesse contexto, o fracasso escolar das crianças de classes subalternas era explicado a partir de uma visão não-negadora do capitalismo. A "teoria da carência cultural" atendia aos requisitos da produção científica predominante na época e confirmava crenças arraigadas na cultura brasileira a respeito da incapacidade dos pobres, negros e mestiços (PATTO, 1999).

Entre 1965 e 1970, sobretudo nas universidades e na produção acadêmica de psicólogos e pedagogos, ocorreu uma permanência de estudos psicopedagógicos, muitos dos mesmos visavam a pesquisa de instrumentos de medida psicológica, especialmente de habilidades específicas com o objetivo de aplicá-los no esclarecimento das causas das dificuldade de aprendizagem escolar (PATTO, 1999).

Durante as décadas de 1970 e 1980, na Educação Especial brasileira, foram intensificadas as discussões a respeito da integração. Foram feitas muitas 
críticas a recursos e modalidades de atendimento, interpretados como sendo segregativos, o que ocasionou até mesmo propostas de eliminação destes serviços. A colocação em ambientes domiciliares foi criticada, assim como as escolas especiais igualmente sofreram críticas baseadas no argumento de que estas inevitavelmente causariam a segregação (OMOTE, 1999).

Nos Estados Unidos, o Conselho Nacional de Reabilitação definira em 1943 o conceito de reabilitação como restauração no nível mais alto de todas as capacidades físicas, mentais, sociais e vocacionais dos deficientes de qualquer tipo. Pereira (1977) utiliza esta definição em uma publicação que apresenta especificações para implantação de serviços de preparo do excepcional para a integração na força de trabalho.

O enclausuramento que anteriormente significava uma possibilidade para que este desviante não fosse um incômodo para a sociedade, neste momento representava um ônus aos cofres públicos. Além disso, Jannuzzi (1997) ressalta que no modo de produção capitalista, a figura do deficiente representa um consumidor em potencial, portanto, alvo de possíveis investimentos.

Em verdade, na vida cotidiana, a ação e o pensamento manifestam-se e funcionam na exata medida em que são imprescindíveis à continuidade (PATTO, 1999). Logo, à medida que a participação das pessoas com deficiência no cenário da economia foi considerada relevante, as ações relacionadas ao atendimento dispensado a estas passaram a funcionar de maneira diferenciada por serem consideradas importantes para a perpetuação da hegemonia do modo de produção capitalista. Vejamos um trecho extraído de uma publicação do Ministério da Educação e Cultura de 1977:

Trabalhar é situação normal na sociedade em que vivemos, inclusive para o excepcional, que completa seu processo educativo quando está apto a ser incorporado à força de trabalho da comunidade em que vive (PEREIRA, 1977, pág. 13).

De acordo com Miranda (2003), a década de 1980 representou um tempo de lutas a favor das populações marginalizadas. O Brasil enfrentava um momento de grandes modificações, haja vista que vivia-se um processo de democratização após 21 anos de ditadura militar. Disseminou-se uma grande discussão acerca dos direitos da pessoa com deficiência, ocasionando uma mudança fundamental na política de atenção às pessoas com deficiência, através do afastamento do paradigma da institucionalização e a introdução, na prática social, do paradigma de 
serviços/integração em que buscava-se fundamentalmente o preparo e o desenvolvimento dessa população para o estado de normalidade, condição considerada necessária para a integração social (ARANHA, 2000).

Nesse momento de visibilidade dos movimentos sociais, segundo Bieler (1990), o trabalho das lideranças referentes à população com deficiência significou a mudança de postura em relação a essas pessoas. O paternalismo teria que dar lugar à equiparação de oportunidades. A tutela substituída pela cidadania (p.23).

Era objetivo que estes sujeitos se assemelhassem à normalidade para que fosse efetivado o processo de integração social. Como exemplo, Freitas (2012) destaca que no INES, referência de atendimento para pessoas com deficiência auditiva, no final década de 1980, foram admitidos professores que não dominavam Língua Brasileira de Sinais (Libras), língua utilizada pelos alunos.

Nesse contexto, o CENESP perdeu força e foi transformado em secretaria. A partir de 1985, o país estava sob o entusiasmo da Nova República. O slogan "tudo pelo social” era repetido pelo Governo Sarney (1985-1990) e pelos meios de comunicação de massa com o objetivo de canalizar as diretrizes da nação. Durante este governo, surgiram tentativas para melhorar condições sociais, através de políticas compensatórias na educação, saúde, habitação, saneamento básico etc. Em relação ao atendimento à pessoa com deficiência, destaca-se a criação da Coordenadoria para Integração da Pessoa Portadora de Deficiência, em 1986 (JANNUZZI, 2004).

Patto (1999) destaca que em 1980 foram publicados diversos artigos que tratam da democratização do ensino que partem da crença na deficiência/diferença da clientela majoritária da escola pública de primeiro grau em relação aos seus pares de classe média e alta. A autora destaca que nestes estudos, também há referência à necessidade de verificar o grau de adequação entre as propostas e orientações curriculares, a forma de trabalho do professor e à importância de realizar alterações curriculares que atentem para as reais condições de aprendizagem da maioria da população em idade escolar.

A lei n. 7853 de 24 de outubro de 1989 incluía entre as medidas, na área da educação, a matrícula compulsória em cursos regulares de estabelecimentos públicos e particulares de pessoas com deficiência capazes de se integrarem no sistema regular de ensino. Esta medida está em concordância com a definição de 
integração proposta por Sassaki (2005), em que o termo se refere à inserção de sujeitos aptos no ambiente escolar.

No seu artigo 17, determina que seja levantado o número de deficientes. Diante disso, no censo populacional do Instituto Brasileiro de Geografia e Estatística (IBGE) de 1991 havia um item específico para contabilizar o percentual de pessoas com deficiência. Partindo de características muito específicas para conceituação de cada categoria de deficientes, os dados apontaram uma incidência de $1,5 \%$. Este índice é muito inferior aos apontados pela ONU que seriam de $10 \%$ nos países em desenvolvimento e mesmo aos encontrados pelo IBGE na Pesquisa Nacional de Domicílios (PNAD) em 1981 de 1,78\%, na Pesquisa Nacional de Saúde e Nutrição (PNSN) em 1989 de 8,83\%, no Programa das Nações Unidas para o Desenvolvimento Humano (PNUD) em 1997 de 3,7\% (JANNUZZI, 2004).

Além de o momento histórico não ser favorável a todas as pessoas com deficiência, considerando que as políticas e as ações relacionadas à educação especial atendiam substancialmente à população com deficiência que poderiam se assemelhar aos ditos normais, a concepção de deficiência não abrangia sujeitos que são assim categorizados atualmente. Logo, muitas pessoas com deficiência podem ter negado a assunção de sua condição. Esta negação pode ter relação com dificuldades de identificação, o preconceito do informante, entre outros fatores (JANNUZZI, 2004). De acordo com Patto (1999), o preconceito constitui um juízo provisório. Este é um juízo falso, ou seja, um juízo que poderia ser corrigido a partir da experiência do pensamento, do conhecimento e da decisão moral. Se esta correção não ocorre, o preconceito confirma ações anteriores o que é compatível com a conformidade e o pragmatismo da vida cotidiana e protege de conflitos. Os preconceitos têm a função de consolidar a manter a estabilidade e a coesão de integrações sociais, principalmente das classes sociais.

O Censo de 1991 mostra que 59\% da população com deficiência se situa na categoria "sem instrução". Além disso, apenas 11, 64\% de pessoas com deficiência completaram quatro anos de estudo e $15,45 \%$ possuíam de um a três anos de estudo. Principalmente, na década de 1990, a apropriação do conhecimento escolar passou a ser enfatizada no nível do discurso como essencial para o trabalho (JANNUZZI, 2004).

No cenário internacional, as discussões sobre inclusão tomaram impulso neste período. Como exemplo disso, destaca-se a Declaração de Jomtien aprovada 
no início do ano de 1990, documento que abordava de maneira significativa a educação de populações marginalizadas.

Rodrigues (2010) considera que a Constituição Federal da República Federativa do Brasil de 1988 apresentou grandes modificações no cenário da educação especial no país. Em seu artigo 208, estabelece a integração escolar como preceito constitucional, preconizando o atendimento às pessoas com deficiência, preferencialmente na rede regular de ensino (MIRANDA, 2004).

A lei n. ${ }^{\circ}$ 8069/90 que dispõe sobre o Estatuto da Criança e do Adolescente (ECA) determina no artigo 54 que é dever do Estado assegurar à criança e ao adolescente portadores de deficiência atendimento educacional especializado, preferencialmente na rede regular de ensino. Drago (2005) traz uma reflexão sobre o uso do termo preferencialmente, onde o mesmo afirma que ter predileção não significa obrigatoriedade, sendo assim o Poder Público não é obrigado a aceitar tais crianças e adolescentes em suas instituições. Da mesma forma, o autor entende que o uso do termo sugere que existem deficiências que a escola regular ainda não está preparada para atender/atender satisfatoriamente, cabendo a espaços especializados este atendimento, visto que estes lugares geralmente contam com serviço fonoaudiológico, terapêutico, médico, dentre outros.

A Coordenação de Educação Especial, do Departamento de Educação Supletiva e Especial da Secretaria Nacional de Ensino Básico (SENEB), elaborou em 1990 um documento intitulado Proposta do Grupo de Trabalho Instituído pela Portaria $n^{\circ} 6$ de 22/08/90. O objetivo da Proposta era "coordenar e promover a operacionalização das diretrizes básicas que norteiam o atendimento educacional dos educandos que apresentam necessidade educativa especial". $\mathrm{Na}$ "Fundamentação Geral" do documento é destacado que no Brasil o princípio que norteia a educação especial é a normalização e a integração é uma alternativa adotava como meio para implementá-la (MAZZOTTA, 1996).

Segundo Mazzotta (1996), as principais tendências que caracterizam as políticas de educação especial em âmbito nacional até 1990 são a centralização do poder de decisão e execução, atuação marcadamente terapêutica e assistencial ao invés de educacional e ênfase ao atendimento realizado por instituições especializadas particulares.

Segundo Jannuzzi (2004), a partir do final do século XX, a atuação do Estado diminuiu efetivamente e, em certos setores como a educação, foi 
desprestigiada. Em muitos casos o setor privado e as organizações não-governamentais suprem a obrigatoriedade estatal em relação à saúde e à educação.

De acordo com Koselleck (2006), documentos e fatos permanecem relacionados. Logo, as iniciativas de integração escolar estão vinculadas à inserção do conceito nos documentos. O paradigma da integração se tornou hegemônico, porque se considerou essencial a participação ativa na sociedade de pessoas com deficiência consideradas capazes de exercer atividades cotidianas, como o trabalho, sem a necessidade de adaptações. 


\section{4. A emergência do paradigma da inclusão}

4. 1.

A Declaração de Jomtien

A Declaração Mundial sobre Educação para Todos foi aprovada pela Conferência Mundial sobre Educação para Todos que ocorreu na cidade de Jomtien na Tailândia de 5 a 9 de março de 1990. Neste documento, são estabelecidas definições e novas abordagens sobre as necessidades básicas de aprendizagem, com o objetivo de definir compromissos mundiais para garantir a todas as pessoas os conhecimentos básicos considerados necessários a uma vida digna, visando uma sociedade mais humana e mais justa ${ }^{24}$. Este documento teve seus princípios reafirmados na Declaração de Salamanca e é considerado por alguns autores extremamente relevante para o campo de conhecimento da educação especial (CORRÊA, 2009; ARANHA, 2004, FERREIRA, 2005). Diante disso, faz-se necessário iniciar a reflexão acerca da emergência do paradigma da inclusão, analisando a Declaração Mundial sobre Educação para Todos.

Os principais responsáveis pela conferência foram a UNESCO (Organização das Nações Unidas para a Educação, Ciência e Cultura), UNICEF (Fundo das Nações Unidas para a Infância), PNUD (Programa das Nações Unidas para o Desenvolvimento) e o Banco Mundial. Participaram também várias representações mundiais como organizações não governamentais, órgãos responsáveis pela Educação, 155 governantes do mundo inteiro e diversas agências internacionais.

Este documento é indicado como um Plano de ação para satisfazer as necessidades básicas de aprendizagem. No documento é afirmado que educação básica adequada é fundamental para fortalecer os níveis superiores de educação e de ensino, a formação científica e tecnológica e, consequentemente, para alcançar um desenvolvimento autônomo. As necessidades básicas de aprendizagem compreendem, segundo o documento, tanto os instrumentos essenciais para a aprendizagem (como a leitura e a escrita, a expressão oral, o cálculo, a solução de pro-

\footnotetext{
${ }^{24}$ Conforme informações obtidas no endereço eletrônico http://www.educabrasil.com.br/eb/dic/dicionario.asp?id=111 no dia 08 de junho de 2012.
} 
blemas), quanto os conteúdos básicos da aprendizagem (como conhecimentos, habilidades, valores e atitudes), necessários para que os seres humanos possam sobreviver, desenvolver plenamente suas potencialidades, viver e trabalhar com dignidade, participar plenamente do desenvolvimento, melhorar a qualidade de vida, tomar decisões fundamentadas e continuar aprendendo.

As ações para satisfação das necessidades básicas de aprendizagem compreendem manifestações que foram articuladas inicialmente na linguagem (KOSELLECK, 2006). Estas necessidades compreendem categorias que foram empregadas no documento, sem fontes que a legitimassem como realmente necessárias. Quais foram os critérios adotados para definir os aspectos citados como necessidades básicas da aprendizagem? A satisfação das necessidades básicas de aprendizagem descritas no documento seria ponto essencial para formar cidadãos aptos para atuar em postos de trabalho relacionados ao processo de produção.

É possível relacionar a Declaração de Jomtien a acontecimentos referentes ao período. No fim do documento, afirma-se que jamais será testemunhado um momento tão propício à renovação do compromisso com o esforço em longo prazo para satisfação das necessidades básicas de aprendizagem de todas as crianças jovens e adultos. Entretanto, não há uma razão explícita para que este momento seja considerado tão favorável.

É importante ressaltar que no momento da elaboração do documento, o cenário internacional atravessava diversas mudanças com o término da Guerra Fria e a queda do comunismo na Europa. No ano de 1989, revoluções se espalhavam, tendo como característica a rapidez do processo e a natureza pacífica (JUDT, 2008). Considerando o caráter pacífico das revoluções, destaco uma afirmativa presente no documento: Hoje, testemunhamos um autêntico progresso rumo à dissensão pacífica e de uma maior cooperação entre as nações (WCEFA, 1990).

O comunismo de uma maneira geral era considerado algo do passado (JUDT, 2008); o modelo econômico-político produzido pelo movimento comunista não representava mais uma alternativa ao capitalismo globalizado. Neste contexto, a educação assumiu um caráter de massificação e conformismo dos indivíduos, considerando as modificações ocorridas nos valores e ideais através da dinamização das forças produtivas; pelas diferentes condições de vida e trabalho (GROPPO, 2008). Ações para satisfação das necessidades básicas da aprendiza- 
gem são uma maneira de satisfazer as demandas de uma relação de produção mais dinamizada.

Essas necessidades básicas de aprendizagem são relacionadas no discurso à sobrevivência. Os documentos permitem acrescentar a dimensão do tempo à compreensão do social (SÁ-SILVA; ALMEIDA et al, 2009), logo a declaração expressa uma concepção de educação presente na época: absolutamente imprescindível.

Em referência às pessoas portadoras de deficiência, é destacado como necessário que se tomem medidas que garantam a igualdade de acesso à educação aos portadores de todo e qualquer tipo de deficiência. A concepção de igualdade adotada remete a uma das definições de Bobbio (2009), sendo esta referente ao nivelamento das oportunidades.

Diante disso, a pessoa com deficiência foi constituída como alvo de ações prioritárias. Anteriormente, principalmente no que diz respeito a pessoas com deficiência intelectual, diversas ações caracterizam uma rejeição política do deficiente como confinamento, esterilização e segregação (PESSOTTI, 1984). No momento da confecção da declaração, o sujeito foi constituído de uma maneira diferenciada. $\mathrm{O}$ clima social ${ }^{25}$ apresentava condições favoráveis para que pessoas, profissionais ou leigos, pessoas com deficiência ou não, despontassem como líderes da sociedade em que viviam para impulsionar propor e organizar medidas para o atendimento às pessoas com deficiência. (MAZZOTTA, 1996).

O conceito de necessidades básicas de aprendizagem presente no documento está fundamentado em sistemas político-sociais complexos. O acesso equitativo a mecanismos que objetivam a satisfação destas necessidades seria uma maneira de assegurar a igualdade. O conceito de igualdade é recorrente, portanto, comum. De acordo com Koselleck (2006), sem conceitos comuns não pode haver unidade de ação política. Este conceito, presente tanto na Declaração de Jomtien quanto na DUDH, foi essencial para o embasamento de diversas políticas, inclusive na área de atendimento da educação especial.

De acordo com Marquezan (2009), as palavras não têm sentido inerente a sua literalidade. Neste sentido, a palavra igualdade, mesmo sendo utilizada em

\footnotetext{
${ }^{25}$ Mazzota (1996) define clima social como conjunto de crenças, valores, ideias, conhecimentos, meios materiais e políticos de uma sociedade em um dado momento histórico.
} 
documentos diversificados, por estar inscrita em formações discursivas diferentes, pode ter significados diferentes.

De acordo com o documento, a amplitude das necessidades básicas e a forma de satisfazê-las seriam variáveis segundo cada país e cada cultura e inevitavelmente mutáveis com o tempo. Além disso, destaca-se que cada país deveria elaborar metas para a década de 1990 que envolvessem a expansão dos cuidados básicos e atividades do desenvolvimento infantil, incluindo as intervenções da família e da comunidade, direcionadas especialmente a crianças pobres, desassistidas e portadoras de deficiência.

No preâmbulo do documento, é feita uma referência à Declaração Universal dos Direitos Humanos. Em destaque, está a afirmativa presente no documento de 1948 de que "toda pessoa tem direito à educação". Alguns dados referentes ao cenário mundial da educação naquele momento também são citados:

- mais de 100 milhões de crianças, das quais pelo menos $60 \mathrm{mi}$ lhões são meninas, não têm acesso ao ensino primário; - mais de 960 milhões de adultos - dois terços dos quais mulheres são analfabetos, e o analfabetismo funcional é um problema significativo em todos os países industrializados ou em desenvolvimento; - mais de um terço dos adultos do mundo não têm acesso ao conhecimento impresso, às novas habilidades e tecnologias, que poderiam melhorar a qualidade de vida e ajudá-los a perceber e a adaptar-se às mudanças sociais e culturais; e - mais de 100 milhões de crianças e incontáveis adultos não conseguem concluir o ciclo básico, e outros milhões, apesar de concluí-lo, não conseguem adquirir conhecimentos e habilidades essenciais (WCEFA, 1990).

A Declaração de Jomtien é citada em documentos que fazem referência ao paradigma da inclusão, considerando a ideia central: proporcionar acesso à educação para todos. Uma educação que tem como objetivo principal a qualificação profissional. Este fator é considerado essencial para o desenvolvimento das nações mais pobres, todavia surge camuflando as intenções de manutenção da hegemonia econômica e política de países imperialistas (GROPPO, 2008).

As grandes empresas geralmente buscam centrar sua produção em países em desenvolvimento, considerando fatores como, por exemplo, a mão-de-obra a baixo custo geralmente disponível nestes países. Diante disso, é necessário que os trabalhadores estejam qualificados, ou seja, tenham suprido as necessidades básicas de aprendizagem. 
$\mathrm{Na}$ perspectiva do paradigma da integração, entende-se que o problema não é a deficiência e sim a situação de dependência. Uma vez que sejam satisfeitas as necessidades básicas de aprendizagem das pessoas com deficiência a partir do acesso à educação para todos, a estas é possibilitado que não estejam em situação de dependência. O paradigma da inclusão, correlacionado ao da integração, prevê que estes sejam incorporados à escolarização regular, independentemente de suas condições, e que haja uma preparação para inserção no mundo do trabalho para uma vida autônoma. Na sociedade inclusiva, autonomia comumente está vinculada com participação no processo produtivo como mão-de-obra. Portanto, a pessoa com deficiência foi considerada no documento como alvo de ações prioritárias por ser necessário que esta se incorporasse ao processo produtivo, deixando de permanecer como mera receptora de benefícios.

\section{2.}

\section{A difusão do paradigma da inclusão}

Na transição do final da década de 1980 para a década de 1990, houve movimentos mundiais de abertura das transações entre fronteiras nacionais e internacionalização. Diante disso, vários países tiveram que adequar suas políticas econômicas para atender os ditames das economias globais, No Brasil, ocorreram privatizações que implicaram, inclusive, no incentivo à competição.

A globalização, processo em que ocorre o aumento do comércio exterior e redução de tarifas, favorece o crescimento e a diminuição da pobreza. Para manutenção do processo de globalização, é importante que uma parcela significativa da população seja consumidora o que é proporcionado por uma sociedade inclusiva.

Nesse contexto, o mito da educação como meio de ascensão social domina o discurso inclusive de profissionais da área de educação e a escola passou a ser entendida como instituição socializadora por excelência (RUCKSTADTER, 2005). Emergem diversas propostas e consequentemente surgem políticas para universalização do acesso à educação básica.

Sánchez (2005) considera relevante o movimento surgido nos Estados Unidos denominado Regular Education Initiative (REI). O ponto crucial deste movimento seria a unificação da educação regular e especial para melhor e mais economicamente atender aos alunos (BRAATEN, KAUFFMAN et al, 1988). 
O REI busca o desaparecimento da educação compensatória, além disso, apresenta uma reflexão sobre a imersão de alunos na educação especial por pertencerem a grupos étnicos minoritários, considerando que a representatividade das minorias neste segmento de ensino sugeriria um aspecto racista da continuidade de programas separados (SANCHÉZ, 2005).

No que diz respeito à inclusão, como relevantes, são destacados o Programa Mundial de Ação Relativo à Pessoa com Deficiência, aprovado em dezembro de 1982 e ainda as Normas sobre Igualdade de Oportunidades para pessoas com Deficiência de 1993 (SASSAKI, 2005).

O Programa de Ação Mundial Relativo à Pessoa com Deficiência foi aprovado pela Assembleia Geral das Nações Unidas pela Resolução 37/52 de 3 de dezembro de 1982. Tinha a finalidade de promover medidas eficazes para a prevenção da deficiência e para a reabilitação e a realização dos objetivos de "igualdade" e "participação plena" das pessoas com deficiência na vida social e no desenvolvimento. Na perspectiva do documento, isto significaria oportunidades iguais às de toda a população a uma participação equitativa na melhoria das condições de vida resultante do desenvolvimento social e econômico.

Os governos devem, segundo o documento, despertar a consciência da população quanto aos benefícios que seriam alcançados com a inclusão das pessoas com deficiência em todas as esferas da vida social, econômica e política. Além disso, devem cuidar para que as pessoas que se encontram em situação de dependência devido a deficiências graves possam alcançar níveis de vida iguais aos seus concidadãos. O documento define a igualdade de oportunidades como processo mediante o qual o sistema geral da sociedade ${ }^{26}$ se torna acessível para todos.

A adoção de políticas que reconheçam os direitos das pessoas portadoras de deficiência à igualdade de oportunidades na educação, é citada como uma obrigação dos Estados Membros. Destaca-se que a integração no sistema geral de educação exige planejamento e os serviços de educação para crianças e/ou adultos portadores de deficiência devem ser individualizados, acessíveis e universais, servindo a todas as pessoas que tenham necessidades especiais.

\footnotetext{
${ }^{26}$ Segundo o documento, o sistema geral da sociedade engloba o meio físico e cultural, a habitação, o transporte, os serviços sociais e de saúde, as oportunidades de educação e de trabalho, a vida cultural e social, inclusive as instalações esportivas e de lazer.
} 
Em relação à integração das pessoas portadoras de deficiência no mercado de trabalho, afirma-se que os Estados Membros podem apoiá-la mediante diversas medidas como sistemas de cotas com incentivos, reserva ou designação de cargos, auxílios ou doações para pequenas empresas ou cooperativas, contratos exclusivos ou direitos prioritários de produção, isenções fiscais, aquisições preferenciais ou outras modalidades de assistência técnica ou financeira a empresas que empreguem trabalhadores com deficiência. A política de incentivos às empresas empregadoras de pessoas com deficiência pode garantir que uma parcela desta população seja de fato economicamente ativa.

As Normas para Equiparação de Oportunidades para Pessoas com Deficiência da ONU foram adotadas pela Assembleia Geral das Nações Unidas na resolução 48/96 de 20 de dezembro de 1993. No documento, é sinalizado que há pessoas com deficiência em todas as partes do mundo e em todas as camadas sociais e que o número de pessoas com deficiência é elevado e continua a aumentar.

A política da época em matéria de deficiência é atribuída à evolução registrada ao longo dos últimos 200 anos. É feita uma breve referência à história do atendimento dispensado às pessoas com deficiência; a evolução desde a prestação de cuidados básicos nas instituições até a educação de crianças com deficiência e a reabilitação das pessoas que se tornaram deficientes na fase adulta.

Os conceitos de integração e normalização são citados. Segundo o documento, a introdução destes após a Segunda Guerra Mundial, reflete um conhecimento cada vez mais profundo das capacidades das pessoas com deficiência.

As regras expostas não são de cumprimento obrigatório, mas podem ser convertidas em normas de direito internacional consuetudinário. O objetivo das normas consiste em garantir que pessoas com deficiência, na condição de membros de comunidades, possam exercer os mesmos direitos e estar sujeitas às mesmas obrigações dos demais cidadãos.

No mundo inteiro durante os anos 1990, houve crescentes iniciativas a favor da infância. Foi um período de destaque na história da infância, considerando que até então a criança não havia recebido tantos defensores. Em pauta, estavam assuntos como a proteção à infância, o direito a ter um lar e de ter a própria cultura, religião e língua. Além disso, destaca-se o direito a uma educação em igualdade de condições (DELGADO, 2000). Segundo Frigotto e Ciavatta (2003), durante essa década os organismos internacionais exerceram diversas ações em ter- 
mos organizacionais e pedagógicos, com destaque para a realização de grandes eventos, assessorias técnicas e farta produção documental.

\section{3.}

\section{A inclusão e a Declaração de Salamanca}

A Declaração de Salamanca é um documento relacionado ao paradigma da inclusão. Foi produto da Conferência Mundial de Educação Especial em junho de 1994, onde diversos governos e organizações mundiais reafirmaram seu compromisso para com a Educação para Todos. Trata do reconhecimento da necessidade e da urgência do providenciamento de educação para as crianças, jovens e adultos com necessidades educacionais especiais dentro do sistema regular de ensino. $\mathrm{O}$ documento é um texto instrucional; fornece orientações sobre como os EstadosPartes deveriam conduzir suas políticas.

Consta neste documento que os delegados da Conferência acreditam e proclamam que:

- toda criança tem direito fundamental à educação, e deve ser dada a oportunidade de atingir e manter o nível adequado de aprendizagem,

- toda criança possui características, interesses, habilidades e necessidades de aprendizagem que são únicas,

- $\quad$ sistemas educacionais deveriam ser designados e programas educacionais deveriam ser implementados no sentido de se levar em conta a vasta diversidade de tais características e necessidades,

- aqueles com necessidades educacionais especiais devem ter acesso à escola regular, que deveria acomodá-los dentro de uma Pedagogia centrada na criança, capaz de satisfazer a tais necessidades,

- escolas regulares que possuam tal orientação inclusiva constituem os meios mais eficazes de combater atitudes discriminatórias criando-se comunidades acolhedoras, construindo uma sociedade inclusiva e alcançando educação para todos; além disso, tais escolas provêem uma educação efetiva à maioria das crianças e aprimoram a eficiência e, em última instância, o custo da eficácia de todo o sistema educacional (UNESCO, 1994, grifo meu).

No discurso da declaração, a construção de uma sociedade inclusiva está relacionada ao acesso à educação para todos; à oportunidade de atingir e manter o nível adequado de aprendizagem. Esta acessibilidade à instrução, proclamada inclusive pela Declaração de Jomtien, é referente à satisfação das chamadas neces- 
sidades básicas de aprendizagem, essenciais para que todos possam de maneira igualitária fazer uso dos recursos disponibilizados em uma sociedade globalizada.

Certamente, é reconhecido que cada sujeito possui características que lhe são peculiares e que os sistemas de ensino devem se adaptar para fornecer instrução adequada para cada indivíduo. Na inclusão, a diversidade é vista como algo positivo, considerando, no entanto, que sempre será necessário que existam sujeitos para ocupar posições marginalizadas que não precisam ser ocupadas por sujeitos com capacidade considerada plena. $\mathrm{Na}$ sociedade dita inclusiva, existem muitos dogmas referentes às possibilidades de participação da pessoa com deficiência na comunidade: o deficiente visual como massoterapeuta, a pessoa com nanismo como comediante... As comunidades ditas como acolhedoras muitas vezes têm lugares marcados para as pessoas com deficiência incluídas.

Uma das demandas presentes no documento é que os governos adotem o princípio de educação inclusiva em forma de lei ou de política, matriculando todas as crianças em escolas regulares, a menos que existam fortes razões para agir de outra forma. Na perspectiva do paradigma da inclusão, os sistemas de ensino devem se adaptar para atender as necessidades do alunado. Com a matrícula de alunos com necessidades educacionais especiais exclusivamente no ensino regular, seria possível que um número menor de profissionais da educação fosse disponibilizado e não se faria necessário a manutenção de instituições especializadas.

Santos (2002) afirma que na versão brasileira da Declaração de Salamanca foram omitidas três seções inteiras, sendo estas: Parte 1 - Educação para Necessidades Especiais: uma visão geral, Parte 2 - A Conferência e Parte 3 - Resumo das Apresentações Temáticas e Discussões. A autora ressalta que esta é uma observação importante, pois nas partes omitidas residem discussões que embasaram toda movimentação a favor da inclusão. Além disso, nos trechos citados, há alternância na utilização dos termos integração e inclusão, ora como sinônimos, ora como termos diferentes, mas complementares.

Afirma-se neste documento, em trecho da versão brasileira, que as escolas devem estar dispostas a receber todos, assim como no trecho destacado abaixo:

O princípio que orienta esta Estrutura é o de que escolas deveriam acomodar todas as crianças independentemente de suas condições físicas, intelectuais, sociais, emocionais, lingüísticas ou outras. Aquelas deveriam incluir crianças deficientes e super-dotadas, crianças de rua e que trabalham, crianças de origem remota ou de população nômade, crianças pertencentes a 
minorias lingüísticas, étnicas ou culturais, e crianças de outros grupos desavantajados ou marginalizados (UNESCO, 1994).

Esse princípio faz referência a indivíduos que ficam fora do grupo universal de referência a que pertencem como seres humanos (KOSELLECK, 2006): sujeitos ditos normais e cidadãos. Aqueles que são contemplados por essa orientação, alvo das ações inclusivas, estão excluídos. O conceito de exclusão remete ao conceito de inclusão, assim como remete ao conceito de integração. Portanto, não há conceitos de integração ou inclusão sem o conceito de exclusão ou segregação.

De acordo com o documento, há um consenso emergente de que crianças e jovens com necessidades educacionais especiais devam ser incluídas em arranjos educacionais feitos para a maioria das crianças. Esta ideia conduziu ao conceito de escola inclusiva.

O mérito da escola inclusiva não residiria somente no fato de serem consideradas capazes de prover uma educação de alta qualidade a todas as crianças. $\mathrm{O}$ estabelecimento de tais escolas é, considerado no texto do documento, um passo crucial no sentido de modificar atitudes discriminatórias, de criar comunidades acolhedoras e de desenvolver uma sociedade inclusiva (UNESCO, 1994).

Além disso, a Educação Especial assume que as diferenças humanas são normais e incorpora princípios descritos como mais que comprovados de uma pedagogia de que todas as crianças possam se beneficiar. Cabe destacar a afirmativa de que uma pedagogia centrada na criança é beneficial a todos os estudantes e, consequentemente, à sociedade como um todo (UNESCO, 1994).

No texto do documento consta que uma pedagogia centrada na criança é capaz de "impedir o desperdício de recursos e o enfraquecimento de esperanças", elementos considerados consequências de uma instrução dita como de baixa qualidade e de uma mentalidade educacional baseada na ideia de que "um tamanho serve a todos".

Em referência ao paradigma da integração, é afirmado que a tendência em política social das duas décadas anteriores à confecção do documento havia sido promover a integração e participação e de combater a exclusão. Os delegados deixam registrado que inclusão e participação são essenciais à dignidade humana e ao desfrutamento e exercício dos direitos humanos (UNESCO, 1994). O que é referente ao conceito de humanidade, seus conceitos derivados, como dignidade humana e direitos humanos, se tornaram uma meta a ser alcançada e que só pode 
ser atingida com educação e participação na comunidade, inclusive no mundo do trabalho.

Um ponto importante é que o documento não prevê a extinção de escolas especiais e classes especiais. $\mathrm{O}$ encaminhamento para tais instituições se daria em situações de exceção e ocorreria em casos infrequentes em que fique demonstrado que a educação na escola regular seja incapaz de atender às necessidades educacionais ou sociais da criança ou quando solicitado em função do bem-estar da criança ou de outras crianças.

O texto faz alusão em alguns trechos à economia, fornecendo subsídios para que o leitor entenda a proposta da escola inclusiva como benéfica aos cofres públicos. O documento faz referência a experiências sucedidas em países em desenvolvimento, todavia não exemplifica, citando qualquer país. $\mathrm{O}$ alto custo de escolas especiais significaria que apenas uma pequena minoria de alunos, em geral uma elite urbana, se beneficiaria delas. Nesta conjuntura, as áreas rurais, consequentemente, permaneceriam desprovidas de serviços. Segundo a estimativa, menos de um por cento das crianças com necessidades educacionais especiais seriam incluídas na provisão existente. Segundo o texto do documento, a experiência sugere que escolas inclusivas são mais bem sucedidas em atrair apoio da comunidade e em achar modos imaginativos e inovadores de uso dos limitados recursos que sejam disponíveis (UNESCO, 1994).

A legislação dos signatários deveria reconhecer o princípio da igualdade de oportunidade para crianças, jovens e adultos com deficiência na educação primária, secundária e terciária em ambientes integrados, sempre que possível. Bobbio (2009) destaca que a igualdade de direitos não é suficiente para dar acessibilidade a quem é socialmente desfavorecido, para usufruir das mesmas oportunidades destinadas aos indivíduos socialmente privilegiados. Outrossim, ressalta a importância da elaboração de privilégios jurídicos e benefícios materiais para os economicamente desprivilegiados. Estes privilégios e benefícios são essenciais para a "participação ativa na comunidade" e, consequentemente, para manutenção da hegemonia do paradigma da inclusão.

Além disso, há a orientação de que deveriam ser adotadas medidas legislativas paralelas e complementares nos campos da saúde, bem-estar social, treinamento vocacional e trabalho no sentido de promover apoio e tornar eficaz a legislação educacional. 
Possibilitar que pessoas com necessidades especiais saiam da situação de marginalização deveria ser parte integrante de planos nacionais que objetivem atingir educação para todos. Relacionada a esta proposta, citam-se o incentivo à frequência em regime não-integral nas escolas regulares em casos de alunos matriculados em escolas especiais, provisões que visem assegurar a inclusão de jovens e adultos com necessidades especiais em educação secundária e superior, bem como em programas de treinamento, e garantia de igualdade de acesso e oportunidade para meninas e mulheres portadoras de deficiência.

As propostas citadas visam atingir a desmarginalização de crianças portadoras de deficiência. Segundo Godoy (2002), marginalização não é apenas falta de participação de certos setores sociais no consumo dos bens materiais e culturais da sociedade, mas resultado lógico do desenvolvimento modernizador numa sociedade onde o acesso aos benefícios está desigualmente repartido.

Arranjos políticos e de financiamento deveriam encorajar e facilitar o desenvolvimento de escolas inclusivas. O monitoramento do progresso em direção à inclusão deveria se dar, segundo a declaração, através do agrupamento de estatísticas capazes de revelar o número de estudantes com deficiência que se beneficiam dos recursos, know-how e equipamentos direcionados à educação especial, bem como o número de estudantes com necessidades especiais matriculados em escolas regulares.

Outrossim, é destacada a necessidade de realização de um esforço especial no sentido de atrair apoio comunitário à provisão de serviços educacionais especiais. A afirmativa demonstra uma tendência presente em muitos países no fim do século XX: órgãos e instituições de origem não-governamental assumindo funções que deveriam ser cumpridas pelo Estado.

Destaca-se que, para que haja contribuição para escolas inclusivas bem-sucedidas, são necessárias mudanças em aspectos da escolarização, assim como em outros: currículo, prédios, organização escolar, pedagogia, avaliação, pessoal, filosofia da escola e atividades extra-curriculares. A afirmação ressalta a principal característica do paradigma da inclusão: a adaptação das estruturas para atender pessoas com necessidades educacionais especiais.

O documento exalta a importância de manter parcerias com os pais, de que haja envolvimento da comunidade, reconhecendo a ação de organizações voluntárias e não-governamentais e conscientização pública com a utilização da mídia. 
Há a proposta de criação de um banco de dados para o colecionamento de indicadores de progresso que sejam comparáveis a respeito da educação inclusiva e emprego, formando um banco mundial de dados sobre a educação. A proposição é destinada a organizações internacionais, porém o documento não faz referência a qualquer uma.

São apresentadas considerações sobre a prevenção às deficiências que, em alta porcentagem, possuem relação direta com falta de informação, pobreza e baixos padrões de saúde. Em trecho do documento, afirma-se que

... deveria haver uma ação conjunta internacional em estreita colaboração com esforços nacionais, no sentido de se prevenir as causas de deficiências através da educação a qual, por, sua vez, reduziria a incidência e o prevalecimento de deficiências, portanto, reduzindo ainda mais as demandas sobre os limitados recursos humanos e financeiros de dados países (UNESCO, 1994).

É possível constatar que o foco na prevenção às deficiências não é tão somente humanitário. Prevenir através de medidas educacionais é menos oneroso do que investir em escolas especiais, programas de reabilitação, entre outros serviços destinados a pessoas com deficiência.

O texto do documento apresenta instruções aos Estados escritas majoritariamente com verbos no tempo futuro do pretérito do indicativo. O documento dá credibilidade a princípios referentes ao paradigma da inclusão, exaltando práticas relacionadas à escola inclusiva. Entretanto, faz-se necessário refletir sobre aspectos presentes nas entrelinhas do documento, como o reconhecimento de que uma proposta de educação inclusiva pode minimizar os custos financeiros no processo educacional. Os sujeitos antes destinados a um modelo educacional dito como segregado, uma vez inseridos numa sociedade inclusiva, podem participar ativamente e não representarem, por exemplo, mais despesas à previdência social.

No paradigma da inclusão, propõe-se reconhecer as peculiaridades, os aspectos singulares, para realizar adaptações que tornem possível uma instrução considerada adequada a fim de instaurar, paradoxalmente, comportamentos socialmente aceitos que possibilitem o acolhimento na sociedade chamada de inclusiva.

Para além disso, na perspectiva do conceito de inclusão, a distinção entre aqueles que estão dentro e fora dos setores de participação ativa na sociedade deixa de existir, em teoria, em prol de uma humanidade única. 


\section{4.}

\section{A educação no Brasil em tempos de inclusão}

Somente a partir da década de 1990, momento em que o paradigma da integração havia sido propagado em diversos países, as pessoas com deficiência são incluídas nos dados do censo no Brasil. De acordo com o censo do IBGE/2000, $14,45 \%$ da população brasileira apresentava algum tipo de deficiência (LANCELLOTTI, 2003) o que significa um aumento considerável em relação ao ano de 1991 em que o percentual atingiu 1,5\% da população. As políticas e ainda os textos legais demonstram modificações referentes ao paradigma da inclusão.

Essa década foi marcada pela retomada das eleições diretas após 30 anos de ditadura. Neste período, houve um processo de flexibilização das leis trabalhistas e a CLT (Consolidação das Leis do Trabalho) passa a ser interpretada na ótica do neolibralismo como empecilho para as relações trabalhistas e obstáculos na geração de empregos (AGUIAR, 2011). Como exemplo, a lei n. ${ }^{\circ} 8.213$ de julho de 1991 que Dispõe sobre os Planos de Benefícios da Previdência e dá outras providências, abordando inclusive a contratação de portadores de necessidades especiais. No artigo 93, determina-se que empresas com 100 ou mais empregados estão obrigadas a preencher de $2 \%$ a $5 \%$ dos seus cargos com beneficiários reabilitados ou pessoas portadoras de deficiência habilitadas.

As discussões sobre educação têm sido atreladas à formação de mão-deobra para o mercado de trabalho. A instrução é interpretada como uma forma de abastecer este mercado e dar condições aos escolares de competir bem formados no mercado de trabalho. Com a inclusão das pessoas com deficiência nas escolas regulares, os sujeitos tenderiam a adquirir mais autonomia e, desta maneira, haveria menos necessidade de recorrer aos cofre públicos através da concessão de benefícios.

Segundo Jannuzzi (2004), há um certo “otimismo pedagógico especial” em relação à inclusão. A autora considera que há diferenças essenciais entre o otimismo atual e o da década de $1930^{27}$. O conhecimento evoluiu em todos os cam-

\footnotetext{
${ }^{27}$ Segundo Nagle (1974), o entusiasmo pela educação e o otimismo pedagógico, caracterizavam a década de 1920. Consistiam em atribuir importância cada vez maior ao tema da instrução, nos seus diversos níveis e tipos.
} 
pos, havendo até tecnologias disponíveis que podem facilitar, em muitos casos, a apreensão e a mobilidade.

Mazzotta (1996) considera que o sentido assistencial e terapêutico atribuído à educação especial, pelo Ministério da Educação (MEC), permaneceu explícito até 1990. Neste ano, em documento oficial, o MEC reconheceu que a educação especial está inserida no contexto global da proposta de educação para todos. Outrossim, afirma que a análise dos textos legais, planos educacionais e documentos oficiais revela que a partir de 1990, o MEC buscou alternativas que viabilizassem a inclusão de portadores de deficiências, problemas de conduta (condutas típicas) e superdotados (com altas habilidades) na rede regular de ensino.

O decreto n. ${ }^{\circ} 99.710$ de 21 de novembro de 1990 promulga a Convenção sobre os Direitos da Criança. No artigo 2, é decretado que os Estados-Partes respeitarão os direitos enunciados na Convenção e assegurarão sua aplicação a cada criança sujeita à sua jurisdição, sem distinção alguma, independentemente de raça, cor, sexo, idioma, crença, opinião política ou de outra índole, origem nacional, étnica ou social, posição econômica, deficiências físicas, nascimento ou qualquer outra condição da criança.

No artigo 23, os Estados-Partes reconhecem que a criança portadora de deficiências, físicas ou mentais, deverá desfrutar de uma vida plena e decente em condições que garantam a dignidade, favoreçam a autonomia e facilitem sua participação ativa na comunidade. Além disso, é especificado que a assistência à criança deficiente será gratuita sempre que possível, considerando a situação econômica dos pais ou das pessoas que cuidem da criança, e visará assegurar à criança o acesso efetivo à educação, à capacitação, aos serviços de saúde, aos serviços de reabilitação, à preparação para o emprego e às oportunidades de lazer, de modo que a criança atinja a mais completa integração social possível e o maior desenvolvimento individual factível, inclusive seu desenvolvimento cultural e espiritual.

A Lei de Diretrizes e Bases da Educação Nacional (lei n. ${ }^{\circ}$ 9394/96) no capítulo $\mathrm{V}$ permite que educandos portadores de necessidades especiais sejam atendidos em classes, escolas ou serviços especializados, sempre que em função das suas condições específicas, não for possível a sua integração nas classes comuns de ensino regular. Na perspectiva de Lancellotti (2003), a escola funcionaria como 
uma instância de pré-seleção daqueles sujeitos que, presumidamente, não se integrariam às relações de produção.

No artigo 59, é determinado que os sistemas de ensino assegurarão aos educandos com necessidades especiais currículos, métodos, técnicas, recursos educativos e organização específicos, para atender às suas necessidades. A adaptação destes fatores em resposta às reais necessidades dos alunos indica a presença do paradigma da inclusão.

Em parágrafo único, é afirmado que o Poder Público adotará a ampliação do atendimento aos educandos com necessidades educacionais especiais na própria rede regular de ensino como alternativa preferencial, independentemente do apoio a instituições privadas sem fins lucrativos, especializadas e com atuação exclusiva da educação especial.

Há destaque para a lei n. ${ }^{\circ} 7853$ de 24 de outubro de 1989 que descreve os direitos das pessoas portadoras de deficiência e ainda define quais sujeitos são reconhecidos como tal. Esta lei foi regulamentada em 1999, durante o Governo Fernando Henrique Cardoso (1995-2002), pelo decreto 3298 de 24 de dezembro que dispõe sobre a Política Nacional para Integração da Pessoa Portadora de Deficiência e outras normas e providências (JANNUZZI, 2004). No capítulo III, são descritas as diretrizes do decreto. Dentre elas, destaca-se a inclusão da pessoa portadora de deficiência, respeitando as suas peculiaridades, em todas as iniciativas governamentais relacionadas, entre outros aspectos, à educação, à saúde, ao trabalho e à previdência social.

No capítulo VII que trata Da Equiparação de Oportunidades, na Seção II que trata Do Acesso à Educação, no artigo 25, são abordados os serviços de educação especial a serem ofertados nas instituições de ensino público ou privado do sistema de educação geral de forma transitória ou permanente. Estes são oferecidos mediante programas de apoio para o aluno integrado no sistema regular de ensino, ou em escolas especializadas exclusivamente quando a educação das escolas não puder satisfazer as necessidades educativas ou sociais do aluno ou quando necessário ao bem-estar do educando. $\mathrm{O}$ uso do termo integrado indica a presença do paradigma da integração que cogita em sua essência a possibilidade do ensino regular ser ideal apenas para aqueles sujeitos que conseguem se assemelhar aos ditos normais. 
A Resolução da Câmara de Educação Básica do Conselho Nacional de Educação(CNE/CEB) n. ${ }^{\circ} 2$ de 11 de setembro de 2001 institui as Diretrizes nacionais para a educação especial na educação básica. $\mathrm{O}$ documento descreve como deve se dar o atendimento de alunos com necessidades educacionais especiais, considerando suas condições específicas, aborda a formação dos professores e discorre sobre o ensino em escolas regulares e em escolas especiais.

De acordo com as Diretrizes nacionais para a educação especial na educação básica (2001),

(...) Entende-se por inclusão a garantia, a todos, do acesso contínuo ao espaço comum da vida em sociedade, sociedade essa que deve estar orientada por relações de acolhimento à diversidade humana, de aceitação das diferenças individuais, de esforço coletivo na equiparação de oportunidades de desenvolvimento, com qualidade, em todas as dimensões da vida.

Como parte integrante desse processo e contribuição essencial para a determinação de seus rumos, encontra-se a inclusão educacional (p. 20).

Nesse contexto, cada aluno requer diferentes estratégias pedagógicas que proporcionem o acesso à herança cultural, ao conhecimento socialmente construído e a vida produtiva, elementos considerados essenciais para a inclusão social e o exercício pleno da cidadania.

No documento, é afirmado que a construção de uma sociedade inclusiva é um processo de fundamental importância para o desenvolvimento e manutenção de um Estado democrático. Koselleck (2006) destaca que a expressão democracia foi transformada em conceito universal de organização, que todas as correntes reinvidicam para si de diferentes maneiras. O conceito de democracia, na condição de conceito universal, pode ser assumido em diferentes perspectivas, tanto vinculado ao paradigma da inclusão, quanto ao paradigma da integração correlacionado a ele.

Com a adoção do conceito de necessidades educacionais especiais, ampliase a ação da educação especial, passando a abranger não apenas as dificuldades de aprendizagem provenientes de condições, disfunções, limitações e deficiências, mas também àquelas não vinculadas a uma causa orgânica específica.

O critério para seleção da clientela da educação especial depende significativamente dos padrões baseados em uma maioria do ensino regular, sendo a capacidade de adaptação a este um pré-requisito de normalidade (JANNUZZI, 
1997). Segundo o documento, educandos com necessidades educacionais especiais são aqueles que demonstram durante o processo educacional:

2.1 - dificuldades acentuadas de aprendizagem ou limitações no processo de desenvolvimento que dificultem o acompanhamento das atividades curriculares, compreendidas em dois grupos:

2.1.1 - aquelas não vinculadas a uma causa orgânica específica;

2.1.2 - aquelas relacionadas a condições, disfunções, limitações ou deficiências.

2.2 - dificuldades de comunicação e sinalização diferenciadas dos demais alunos, demandando adaptações de acesso ao currículo, com utilização de linguagens e códigos aplicáveis;

2.3 - altas habilidades/superdotação, grande facilidade de aprendizagem que os leve a dominar rapidamente os conceitos, os procedimentos e as atitudes e que, por terem condições de aprofundar e enriquecer esses conteúdos, devem receber desafios suplementares em classe comum, em sala de recursos ou em outros espaços definidos pelos sistemas de ensino, inclusive, para concluir, em menor tempo, a série ou etapa escolar (BRASIL, 2001, p. 39).

No documento é destacado que o conceito de necessidades educacionais especiais é amplo. Em vez de focalizar a deficiência da pessoa, enfatiza o ensino e a escola, da mesma maneira as formas e condições de aprendizagem. Não se busca no aluno a origem de um problema. Define-se pelo tipo de resposta educativa e de recursos e de apoios que a escola deve proporcionar-lhe para que obtenha sucesso escolar. Em suma, aponta para a escola o desafio de ajustar-se para atender à diversidade de seus alunos.

Além disso, segundo essas diretrizes, a política de inclusão de alunos que apresentam necessidades educacionais especiais na rede regular de ensino não se refere apenas à permanência física desses alunos junto aos demais educandos, mas representa a ousadia de rever paradigmas e concepções, suas diferenças e atendendo suas necessidades.

As Diretrizes definem Educação Especial como modalidade da educação escolar, como processo educacional definido em uma proposta pedagógica que assegure um conjunto de recursos e serviços educacionais especiais, organizados para apoiar, complementar e substituir, em alguns casos, os serviços educacionais comuns a fim de garantir a educação escolar e promover o desenvolvimento das potencialidades dos educandos com necessidades educacionais especiais em todas as etapas da educação básica. 
A inclusão, nas palavras usadas no documento, representa "um avanço em relação ao movimento de integração escolar". Na utilização do conceito de inclusão nas Diretrizes, não se tinha como objetivo apreender a realidade de alguma forma, mas apontar para o futuro, para mudanças nas ações.

O objetivo dessa proposta seria tornar a escola inclusiva, um espaço considerado democrático e competente para trabalhar com todos os educandos, sem distinção de raça, classe, gênero ou características pessoais, baseando-se no princípio de que a diversidade deve não ser só aceita como desejada (p.40).

Em relação à organização do atendimento na rede regular de ensino, é destacado que a escola regular deverá, ao viabilizar a inclusão de alunos com necessidades educacionais especiais, promover a organização de classes comuns e de serviços de apoio pedagógico especializado. No que diz respeito às classes especiais, poderá ser promovida a sua organização extraordinariamente em caráter transitório.

São definidos como serviços de apoio pedagógico especializado ocorridos no espaço escolar classes comuns, salas de recursos, itinerância e professores-intérpretes. Segundo as diretrizes, a inclusão, meta das políticas de educação, exige interação entre professores das classes comuns e os serviços de apoio pedagógico, sob pena de alguns educandos não atingirem rendimento escolar satisfatório (p.51). Este rendimento escolar satisfatório significa satisfação das necessidades básicas de aprendizagem promulgadas na Declaração de Jomtien.

Ênfase é dada à educação profissional do aluno com necessidades educacionais especiais, sendo considerada um direito. Para um processo de inclusão social, as escolas das redes de educação profissional podem, inclusive, avaliar as competências laborais de pessoas com necessidades especiais não matriculadas em seus cursos, encaminhando-as para o mundo do trabalho.

Em relação aos professores das classes comuns e da educação especial, o documento destaca que as escolas da rede regular de ensino devem prever e prover profissionais capacitados. Para atuação em classes comuns, é necessário que os profissionais tenham em sua formação conteúdos referentes ao campo de conhecimento da educação especial. As diretrizes fazem referência à formação do professor, pois é a partir dela que as modificações na prática educativa podem iniciar. As mudanças atingem o seio da universidade e consequentemente a for- 
mação profissional, possibilitando que ações referentes aos paradigmas hegemônicos, neste caso o da inclusão, sejam implementadas nas escolas.

No anexo da Lei n. ${ }^{\circ} 10.172$ de 9 de janeiro de 2001 que aprova o Plano Nacional de Educação e dá outras providências, consta que a integração/inclusão do aluno com necessidades especiais no sistema regular de ensino é uma das tendências dos sistemas de ensino. Se isto não for possível, deve-se realizar o atendimento em classes e escolas especializadas. $\mathrm{O}$ uso dos dois termos indica uma não-assunção de posicionamento declarado diante de um determinado paradigma.

Destaca-se que a integração das pessoas com necessidades especiais no campo da aprendizagem, originadas de deficiência física, sensorial, mental ou múltiplas, ou de características como altas habilidades, superdotação ou talentos, é uma diretriz consitucional. Além disso, ressalta-se que o ambiente escolar como um todo deve ser adequado para uma perfeita integração. A proposta é a de uma escola integradora, inclusiva, aberta à diversidade dos alunos, considerando a participação da comunidade fator essencial. Em relação às escolas especiais, a política de inclusão as orienta para prestarem apoio aos programas de integração. As afirmações presentes no Plano Nacional de Educação acabam não contemplando as definições dos conceitos de integração e inclusão.

A Política Nacional de Educação Especial na Perspectiva da Educação Inclusiva foi elaborada pelo Grupo de Trabalho nomeado pela Portaria Ministerial n. ${ }^{\circ} 555$ de 5 de junho de 2007, promulgada pela Portaria n. ${ }^{\circ} 948$ de 9 de outubro de 2007. O objetivo declarado do documento é que alunos com deficiência, transtornos globais de desenvolvimento e altas habilidades/superdotação tenham assegurados o acesso, a participação e a aprendizagem nas escolas regulares. Além disso, o documento fornece orientações aos sistemas de ensino para promover respostas às necessidades educacionais especiais, garantindo:

- Transversalidade da educação especial desde a educação infantil até a educação superior;

- Atendimento educacional especializado;

- Continuidade da escolarização nos níveis mais elevados do ensino;

- Formação de professores para o atendimento educacional especializado e demais profissionais da educação para a inclusão escolar;

- Participação da família e da comunidade;

- Acessibilidade urbanística, arquitetônica, nos mobiliários e equipamentos, nos transportes, na comunicação e informação; 
- $\quad$ Articulação intersetorial na implementação das políticas públicas (SEESP/MEC, 2007).

A educação especial na perspectiva da educação inclusiva, de acordo com a Política, passa a integrar a proposta pedagógica da escola regular, atuando de forma articulada com o ensino comum e orientando para o atendimento às necessidades educacionais especiais de alunos com deficiência, transtornos globais de desenvolvimento e altas habilidades/superdotação.

De acordo com o Decreto legislativo n. ${ }^{\circ} 186$ de 2008 que aprova o texto da Convenção sobre os Direitos das Pessoas com Deficiência e de seu Protocolo Facultativo, assinado em Nova York, em 30 de março de 2007, no artigo 24, referente à educação, os Estados-Partes assegurarão sistema educacional inclusivo em todos os níveis, bem como o aprendizado ao longo de toda a vida a fim de efetivar o direito à educação sem discriminação e com base na igualdade de oportunidades.

Para realização do direito à educação, os Estados-Partes assegurarão que dentre outros itens, as pessoas com deficiência possam ter acesso ao ensino primário inclusivo, gratuito e de qualidade, e ao ensino secundário, em igualdade de condições com as demais pessoas na comunidade em que vivem.

O Decreto 7.611 de 17 de novembro de 2011 que dispõe sobre a educação especial, o atendimento educacional especializado e dá outras providências, foi alvo de discussões de profissionais da área da educação recentemente. Através do documento, é decretado que o dever do Estado com a educação das pessoas público-alvo da educação especial será efetivado, dentre outras diretrizes, pela garantia de um sistema educacional inclusivo em todos os níveis, sem discriminação e com base na igualdade de oportunidades e pela não exclusão do sistema educacional geral sob alegação de deficiência.

Decreta-se neste documento que a oferta da educação especial se dará preferencialmente na rede regular de ensino. Para a educação especial são consideradas matrículas na rede regular de ensino, em classes comuns ou em classes especiais de escolas regulares e em escolas especiais ou especializadas.

Cabe citar o Decreto 7.612 de 17 de novembro de 2011 que institui o Plano Nacional dos Direitos da Pessoa com Deficiência - Plano Viver sem Limite. Entre as diretrizes do Plano Viver sem Limite, decretadas no artigo $3^{\circ}$, destaca-se a garantia de um sistema educacional inclusivo. 
A legislação educacional brasileira permite a coexistência entre escolas especializadas e escolas regulares apesar de ser priorizada a permanência dos alunos com necessidades educacionais especiais no sistema regular de ensino.

\section{5.}

\section{Analisando algumas políticas publicas locais}

As políticas locais que refletem princípios referentes ao paradigma da inclusão, possibilitam que o conceito, cujas modificações que ele libera são iniciadas na linguagem, seja pensado de acordo com a realidade de cada localidade e a possibilidade de aplicação dos seus princípios. Diante disso, foram aqui destacados alguns documentos de abrangência local que fazem referência à educação especial.

Inicialmente, buscou-se selecionar um documento referente a um município de cada região do estado do Rio de Janeiro. Isto não foi possível, pois muitos municípios não possuem ou não divulgam documentos como regimento interno ou carta regimento.

O regimento interno da Fundação de Apoio à Escola Técnica (Faetec) foi selecionado, porque esta possuía uma escola de educação especial em sua rede, além disso, o documento se encontrava acessível em um endereço eletrônico ${ }^{28}$.

\section{5. 1.}

Faetec

A Fundação de Apoio à Escola Técnica (Faetec) é integrante da Secretaria de Estado de Ciência e Tecnologia do Governo do Estado do Rio de Janeiro. A instituição disponibiliza ensino de línguas, educação infantil, ensino fundamental, ensino médio, educação profissional, educação especial e educação à distância.

$\mathrm{O}$ regimento interno ${ }^{29}$ da Faetec na seção V trata da Educação Especial. Esta modalidade da educação escolar deve ser oferecida, preferencialmente, nas escolas regulares da rede Faetec, considerando a especificidade dos educandos com necessidades especiais. Segundo o documento, a Educação Especial está fun-

\footnotetext{
${ }^{28} \mathrm{O}$ Regimento interno foi acessado no endereço eletrônico http://www.faetec.rj.gov.br/ouvidoria/images/regimento_escolar_basica_tecnica_faetec.pdf no dia 29 de janeiro de 2013.

${ }^{29}$ O Regimento é seguido pelas escolas da instituição conforme o Decreto n. 22.011 de 09 de fevereiro de 1996.
} 
damentada na concepção dos direitos humanos, pautada pelos princípios éticos, políticos, estéticos e da equidade de modo a assegurar:

I - o respeito da dignidade humana;

II - a busca da identidade;

III - a igualdade de oportunidades;

IV - o exercício da cidadania;

V - a valorização da diferença (FAETEC, 2008).

Os Projetos Pedagógicos das Unidades de Ensino devem garantir atendimento aos alunos em suas peculiaridades, adaptando o currículo e oferecendo uma avaliação diferenciada aos educandos com necessidades especiais, quando necessário.

No artigo 37, é destacado que a Educação Especial será oferecida para a inclusão escolar e/ou em condições específicas, em atendimento educacional especial. Em relação ao Programa de Inclusão, cabe a este a função de mediar a educação inclusiva, orientando as práticas educativas sobre promoção, acesso e permanência de educandos com necessidades especiais e pertencentes a grupos étnico-raciais e demais grupos historicamente discriminados. O documento contempla orientações presentes na Declaração de Salamanca, documento em que são reconhecidos como alvo das políticas de educação inclusiva não só pessoas com deficiências, mas pessoas pertencentes a parcelas da população marginalizadas como, por exemplo, crianças pertencentes a minorias linguísticas e em situação de rua.

A Escola de Educação Especial é destinada a educandos que requeiram atenção individualizada, recursos, apoios intensos e contínuos, assim como adaptações curriculares consideradas tão significativas que a Escola Regular não consiga prover ou sempre que desejar optar por essa modalidade. No entanto, o documento não deixa explícito de quem partiria o desejo pela inserção dos educandos em escolas especiais da Fundação: se dos responsáveis, dos profissionais da educação ou do próprio educando.

No artigo 42, é feita referência ao direito à terminalidade específica, determinado inclusive pela Lei de Diretrizes e Bases da Educação Nacional (lei n. ${ }^{\circ}$ 9394/96). Segundo o regimento da instituição, os alunos que atingirem os 21 anos de idade devem ingressar em turma específica para a terminalidade com o seguinte critério: no primeiro ano, três dias de aulas semanais; no segundo ano, dois dias de aulas semanais e no terceiro, um dia de aula semanal. Os alunos com 30 
anos de idade devem ser desligados, considerando-se que os objetivos propostos pela instituição foram alcançados. Os alunos nesta situação devem receber um histórico escolar, onde constem as competências adquiridas por eles, assim como encaminhamento para Educação de Jovens e Adultos e/ou para Educação Profissional.

Isso garante a rotatividade, que os alunos não permaneçam instituídos indefinidamente. $\mathrm{O}$ estímulo à participação ativa na sociedade através da educação profissional para inserção no mundo do trabalho é uma das características do paradigma da inclusão, presente no regimento interno da instituição. A Faetec fornece subsídios para que sujeitos oriundos de classes menos abastadas sejam capacitados para exercer diversas profissões. Cabe destacar que o atendimento dispensado à pessoa com deficiência desde os primórdios foi associado ao atendimento de classes menos abastadas.

\section{5. 2.}

\section{Município do Rio de Janeiro}

A Resolução n. ${ }^{\circ} 1074$ de 14 de abril de 2010 da Secretaria Municipal de Educação da cidade do Rio de Janeiro dispõe sobre o Regimento Escolar Básico do Ensino Fundamental na Rede Pública do Município do Rio de Janeiro.

Em relação à educação especial, é destacado no artigo $6^{\circ}$ que a política de democratização desenvolvida na rede municipal deve assegurar a melhoria da qualidade de ensino e a valorização da escola pública, em todos os níveis e segmentos, e dos profissionais mediante a garantia de atendimento especial e adequado ao aluno portador de necessidades educativas especiais com o acompanhamento de profissionais capacitados, de acordo com as orientações do Instituto Helena Antipoff (IHA) ${ }^{30}$.

No documento, é garantida à criança ou jovem com deficiência a matrícula em classe regular ou especial, dependendo da manifestação expressa dos responsáveis e, se for julgado como necessário, de avaliação técnica do Instituto Helena Antipoff.

\footnotetext{
${ }^{30}$ O Instituto Helena Antipoff é responsável pela educação especial nas escolas da prefeitura do Rio de Janeiro. Atua na perspectiva da educação inclusiva, acompanhando as diretrizes e propostas da Política Nacional de Educação Especial, conforme informações obtidas no endereço eletrônico http://www.rio.rj.gov.br/web/sme/exibeconteudo?article-id=96318 no dia 29 de janeiro de 2013.
} 


\section{5.3.}

\section{Município de Mesquita}

O regimento escolar da Rede Municipal de Mesquita é o documento considerado instrumento através do qual são estabelecidas diretrizes administrativas, pedagógicas e disciplinares das unidades escolares. As unidades escolares do município devem elaborar seu projeto político-pedagógico, em sintonia com o regimento e com os marcos legais da sociedade brasileira.

A Educação Especial é destacada como uma das modalidades de ensino que compõem a Rede Municipal de Ensino de Mesquita. Segundo o documento, esta modalidade é destinada aos alunos com deficiências educacionais especiais, com duração variável de acordo com o desenvolvimento do estudante no seu processo de ensino-aprendizagem. A oferta se dá preferencialmente através da inclusão em classes de ensino regular e/ou em salas de recursos, conforme a LDB (lei n. ${ }^{\circ}$ 9394/96) e a Resolução n. ${ }^{\circ}$ de 2 de outubro de $2009^{31}$.

Segundo o documento, são objetivos da educação especial:

I. Garantir ao estudante com deficiência a aquisição de conhecimentos através de estratégias de ensino, avaliações específicas, serviços de suporte, adaptações metodológicas e materiais didáticos adequados;

II. Facilitar a inclusão dos estudantes com deficiências ao ensino regular;

III. Ampliar as oportunidades de atendimento à educação especial nas idades iniciais;

IV. Implementar projetos educativos voltados para a educação e o trabalho de estudantes jovens e adultos que, em virtude de deficiências específicas, não concluíram o ensino fundamental e/ou que já não se beneficiam da educação escolar, através de programas vivenciais e parcerias com entidades competentes;

V. Oferecer oficinas pedagógicas ocupacionais como alternativas aos estudantes que não podem se beneficiar de processos didáticos convencionais;

VI. Orientar famílias e comunidade sobre os processos educativos e de integração social dos estudantes com deficiência;

VII. Desenvolver e divulgar estudos e pesquisas em educação especial, em fóruns permanentes, estimulando a formação continuada dos profissionais da educação, famílias e comunidade (SEMED, 2011, p. 4, grifo meu).

\footnotetext{
${ }^{31}$ A Resolução n. ${ }^{\circ} 4$ de 2 de outubro de 2009 institui diretrizes operacionais para o Atendimento Educacional Especializado (AEE) na Educação Básica, modalidade Educação Especial. Dentre os assuntos abordados nesta resolução destacam-se recursos de acessibilidade, projeto pedagógico das escolas, atribuições do professor e as condições de financiamento do AEE.
} 
É destaque que a função da educação especial no município em relação à inclusão é facilitá-la. Além disso, há propostas que visam a participação de jovens e adultos com deficiência em programas educacionais e de inserção no mundo do trabalho o que possibilita uma participação ativa na sociedade e ainda iniciativas para atender ao público que não pode usufruir dos processos didáticos considerados convencionais, através de oficias pedagógicas. Isto reflete uma preocupação em tornar a população com deficiência mais autônoma o que possibilita minimização dos gastos com programas de saúde e reabilitação.

É importante ressaltar que alguns princípios da inclusão estão presentes nos objetivos da educação especial. A adaptação dos métodos e dos serviços para atender as necessidades dos alunos se relaciona diretamente ao paradigma da inclusão.

\section{5.4.}

\section{Município de Niterói}

A Portaria da Fundação Municipal de Educação 878 de 2009 reformula a proposta pedagógica das unidades de educação que constituem a Rede Municipal de Ensino de Niterói. Segundo o documento, a Educação Especial no município se dá na perspectiva da inclusão, observando a legislação vigente sobre a questão.

É considerado como aluno com necessidades educacionais especiais aquele que apresentar no ato de matrícula declaração da família, ou, posteriormente, após avaliação realizada pela Coordenação de Educação Inclusiva da Fundação Municipal de Educação, requerendo quando necessário o diagnóstico da especificidade apontada. Entretanto, a falta de diagnóstico não impede que este aluno receba encaminhamentos pedagógicos realizados pela Equipe do Ciclo da Unidade de Educação.

Com base no parecer da Coordenação de Educação Inclusiva, o aluno com necessidade educacional especial pode frequentar a sala de recursos. Não há referência a escolas especiais e classes especiais no documento o que supõe o entendimento de que a inclusão se dá necessariamente no espaço da escola regular e a função da educação especial seria de complementar e suplementar a educação regular e não substituí-la. 


\section{5.5.}

\section{Município de Petrópolis}

De acordo com a Carta Regimento da Rede Municipal de Ensino, publicada em 17 de janeiro de 2008, a inclusão de alunos portadores de necessidades educativas especiais é obrigatória e na ocasião da matrícula deverá ser exigido laudo médico especializado sobre a deficiência apresentada. Logo, o diagnóstico médico assume importância em detrimento da análise das características singulares dos sujeitos.

De acordo com o documento, a Rede Municipal de Ensino deve assegurar aos educando com necessidades especiais, entre outros aspectos, organização, currículos, métodos, técnicas, recursos educativos e organização específicos para atender às suas necessidades.

O Plano Municipal de Educação de Petrópolis destaca que o atendimento educacional especializado é pautado em dois conceitos fundamentais que permeiam o cotidiano escolar: integração e inclusão. Segundo o documento, integração corresponde ao sentido de incorporação gradativa do sujeito portador de necessidades educativas especiais em escolas regulares, sendo assim, o aluno pode permanecer parte do tempo em escolas ou classes especiais. Logo, um modelo de atendimento destinado àqueles que, por algum motivo, não pudessem se adequar aos espaços destinados à educação regular. A inclusão consiste um sistema educacional modificado, organizado e estruturado para atender às necessidades específicas, interesses e habilidades dos diferentes sujeitos.

O conceito de inclusão é um conceito universal ${ }^{32}$ de organização, reivindicado de diferentes maneiras. Neste caso específico, os documentos aqui citados demonstram que este conceito foi assumido em perspectivas diferentes, segundo o contexto das instituições.

\footnotetext{
${ }^{32}$ Segundo Koselleck (2006) os conceitos universais requerem uma atribuição de sentido, independentemente das experiências concretas ou das expectativas que penetrem neles, apesar de poderem ser assumidos em diferentes perspectivas.
} 
5.

\section{Considerações finais}

O tratamento dispensado à pessoa com deficiência sofreu modificações, por causa da organização das sociedades e da evolução das necessidades do ser humano. Dessa maneira, à medida que o campo da educação passou a atentar para o atendimento à pessoa com deficiência, paradigmas que atendessem às necessidades das sociedades em cada momento histórico, emergiram como hegemônicos.

O paradigma da integração sugere o oferecimento de oportunidades educacionais iguais aos sujeitos, ainda que haja diferenças ocasionadas por deficiências. Na perspectiva do paradigma da inclusão, as adaptações realizadas no ambiente escolar são destacadas com o objetivo de atender as necessidades do público, independentemente de suas condições.

A mera inserção dos conceitos de integração e inclusão nos documentos oficiais não indica mudanças nas práticas nas instituições de ensino, mas demonstra possibilidades de modificações posteriores à confecção de cada documento. Neste sentido, menciono Koselleck (2006) que afirma que os conceitos não representam a apreensão dos fatos, mas apontam para o futuro. Como exemplo disto, os documentos das instituições municipais e estaduais impulsionam transformações políticas e sociais ao empregar o conceito de inclusão nas orientações para as práticas.

É importante destacar que, embora as mudanças ocorram inicialmente na linguagem e os conceitos apontem para o futuro, na história os fatos sempre correspondem a mais ou a menos do que está contido nas condições previamente dadas apesar destas não se modificarem (KOSELLECK, 2006). Para que uma sociedade seja considerada inclusiva, deve seguir certos parâmetros, como atender a todos nas instituições escolares independentemente de suas condições, como consta na Declaração de Salamanca. Em relação a esta condição previamente dada, os fatos têm sido correspondentes a ela?

Os conceitos de democracia, direitos humanos e igualdade foram utilizados para embasar a adoção dos paradigmas da integração e da inclusão. Diante disso, estes conceitos foram reivindicados de diferentes maneiras a fim de justificar a hegemonias de cada paradigma. 
A partir do momento em que, através de um consenso estável dos profissionais do campo de conhecimento da educação especial, o paradigma da integração e posteriormente o paradigma da inclusão se tornaram hegemônicos em momentos distintos o que não se vincula a eles, é considerado exclusão.

Esses conceitos apesar de serem hegemônicos e considerados adequados em momentos diferentes na história da educação especial, não são apresentados como antitéticos nos documentos oficiais. Alguns documentos, como o Plano Nacional de Educação (lei n. ${ }^{\circ}$ 10.172/01), não apresentam diferenciações significativas entre os termos. Drago (2005) destaca que os conceitos de integração e inclusão têm sido confundidos no cotidiano.

Em relação ao paradigma da integração, destaca-se que o mesmo emergiu como hegemônico com a necessidade de reduzir custos com a educação especial no contexto da crise econômica mundial do petróleo. Um momento em que era considerado necessário, inclusive, que as pessoas com deficiência tivessem participação ativa na sociedade.

A transição entre os paradigmas é evidenciada na confecção dos documentos oficiais. Esta mudança possibilitou o surgimento de políticas que objetivam a universalização do acesso à educação básica. A escolarização regular para pessoas com deficiência surge como uma possibilidade de tornar esta população economicamente ativa, através da educação para o trabalho, e minimizar os custos com instituições especializadas, onerosas aos cofres públicos. As modificações dos princípios norteadores na educação especial estão vinculadas às necessidades da sociedade capitalista ou sociedade de consumo.

A partir da década de 1990, deu-se ênfase a ações prioritárias que visassem atender a infância. Nesse contexto, com a emergência do paradigma da inclusão os documentos destacam que os sistemas de ensino devem se adequar para atender as necessidades dos educandos. O dever de adequação das instituições escolares tende a minimizar a atuação de outros setores responsáveis por oferecer outros serviços que seriam necessários às pessoas com deficiência como assistência social e saúde. Consequentemente, os recursos dispensados ao atendimento de pessoas com deficiência podem ser minimizados na perspectiva da educação inclusiva. O paradigma da inclusão contempla as necessidades da sociedade do consumo à medida que possibilita a universalização do acesso à educação básica e possibilita que a população de pessoas com deficiência, considerada como inapta 
durante muitos séculos, tenha participação ativa na sociedade como consumidores.

A partir da promulgação da Declaração de Salamanca, o conceito de inclusão passou a poder ser empregado de forma mais rigorosa, sendo um indicador de transformações políticas e sociais de profundidade histórica (KOSELLECK, 2006). Nas políticas nacionais, inclusive nas locais, principalmente a partir dos anos 2000, o conceito de inclusão tem sido empregado como conceito considerado adequado, visto que, majoritariamente os documentos apresentam termos relacionados ao conceito. A concretização das ações relacionadas ao paradigma da inclusão se torna possível, pois as mudanças são iniciadas na linguagem.

Durante minha análise diversos questionamentos surgiram, acompanhados por algumas inferências: a quem interessa a inclusão? Como as transformações no cenário internacional influenciam na minha prática, na condição de professora atuante no campo de conhecimento da Educação Especial?

Neste trabalho, buscou-se compreender os fatores que influenciaram a transição do paradigma da integração ao paradigma da inclusão. Em relação ao cenário da educação especial no Brasil, foram citados leis e decretos que sugerem mudanças nas práticas exercidas no ambiente escolar. Todavia, não foi possível refletir sobre como se deu esta transição nas instituições de atendimento especializado consideradas como referência o que torna possível outras reflexões sobre a temática.

A legislação brasileira permite a coexistência entre escolas especiais e escolas regulares apesar de ser citado, por exemplo na LDB (9394/96) que a escolarização das pessoas com necessidades educacionais especiais deve ocorrer preferencialmente na rede regular de ensino. Isto demonstra que as instituições especializadas ainda são consideradas essenciais e que a escola regular, apesar da obrigatoriedade em receber alunos independentemente de suas condições, pode não responder às necessidades de todos os alunos. 


\section{Referências bibliográficas}

AGUIAR, M. A. as décadas de 80 e 90: transição democrática e predomínio neoliberal. Rev. De Artes e humanidades, n. 7, nov./abr. 2011.

ARANHA, M. S. F. Um esforço ativo pelo respeito à dignidade das pessoas que apresentam necessidades educacionais especiais. Brasília (DF): Secretaria de Educação Especial / Ministério da Educação, 2000 (Documento para órgãos governamentais).

(org.) Educação inclusiva: v. 1: fundamentação filosófica.

Brasília: Ministério da Educação, Secretaria de Educação Especial, 2004.

BARBY, A. A. O. M.; GARRIDO, M. E. A exclusão permeando as relações das pessoas com deficiência nas sociedades de todos os tempos. In: MENDES, E. G., ALMEIDA, M. A., HAYASHI, M. C. (Org). Anais do III Congresso Brasileiro de Educação Especial/ IV Encontro da Associação Brasileira de Pesquisadores em Educação Especial. São Carlos: Associação Brasileira de Educação Especial, 2008, v. 1.

BARROS, J. D. O Projeto de pesquisa em História: a escolha do tema ao quadro teórico. Petrópolis: Vozes, 2010, p. 11-78.

BAZÍLIO, L. C. Infância "rude" no Brasil: alguns elementos da história e da política. In: GONDRA, J. G (org.). História, infância e escolarização. Rio de Janeiro: 7 letras, 2002, p. 45-58.

BIELER, R. B. (org.). Ética e legislação: os direitos das pessoas portadoras de deficiência no Brasil. Rio de Janeiro: Rotary Club, 1990, 71p.

BOBBIO, N (org.). Dicionário de Política. Brasília: Editora Universidade de Brasília, 13 ${ }^{\text {a }}$ Ed., 2009.

BRAATEN, S.; KAUFFMAN, J. M. et al. The regular education initiative: patent medicine for behavioral disorders. Council for Exceptional Children, v. 55, n. 1, set. 1988 .

BRASIL. Lei ${ }^{\circ} 7.853$, de 24 de outubro de 1989. Dispõe sobre o apoio às pessoas portadoras de deficiência, sua integração social, sobre a Coordenadoria Nacional para Integração da Pessoa Portadora de Deficiência - Corde, institui a tutela jurisdicional de interesses coletivos ou difusos dessas pessoas, disciplina a atuação do Ministério Público, define crimes, e dá outras providências. Brasília, 1989.

BRASIL. Lei 8069 de 13 de julho de 1990. Dispõe sobre o Estatuto da Criança e do Adolescente e dá outras providências. Brasília, 1990.

BRASIL. Decreto n. ${ }^{\circ} 99.710$ de 21 de novembro de 1990. Promulga a Convenção sobre os Direitos da Criança. Brasília, 1990.

BRASIL. Lei n. ${ }^{\circ} 9394$ de 20 de dezembro de 1996. Estabelece as Diretrizes e Bases da Educação Nacional. Brasília, 1996. 
BRASIL. Lei 3298 de 20 de dezembro de 1999. Dispõe sobre a Política Nacional para a Integração da Pessoa Portadora de Deficiência, consolida as normas de proteção, e dá outras providências. Brasília, 1999.

BRASIL. Resolução CNE/CEB n. ${ }^{\circ} 2$ de 11 de setembro de 2001. Institui as Diretrizes nacionais para a educação especial na educação básica. Brasília, 2001.

BRASIL. Lei n. ${ }^{\circ} 10.172$ de 9 de janeiro de 2001. Aprova o Plano Nacional de Educação e dá outras providências. Brasília, 2001.

BRASIL. Decreto legislativo n. ${ }^{\circ} 186$ de 2008. Aprova o texto da Convenção sobre os Direitos das Pessoas com Deficiência e de seu Protocolo Facultativo, assinado em Nova York, em 30 de março de 2007. Brasília, 2008.

BRASIL. Decreto 7.611 de 17 de novembro de 2011. Dispõe sobre a educação especial, o atendimento educacional especializado e dá outras providências. Brasília, 2011.

BRASIL. Decreto 7.612 de 17 de novembro de 2011. Institui o Plano Nacional dos Direitos da Pessoa com Deficiência - Plano Viver sem Limite. Brasília, 2011.

BRASIL. Resolução n. ${ }^{\circ} 4$ de 2 de outubro de 2009. Institui Diretrizes Operacionais para o Atendimento Educacional Especializado na Educação Básica, modalidade Educação Especial. Brasília, 2009.

CALDEIRA, G. C. Revolução francesa e a declaração dos direitos do homem e do cidadão. ETIC, vol. 5, 2009.

CAMPOS, R. H. F. História da psicologia e história da educação - conexões. In: FONSECA, T. N. L; VEIGA, C. G. História e historiografia da Educação no Brasil. Belo Horizonte: Autêntica, 2003, p. 129-158.

CASTRO, A. C.; CASTRO, A. G. et al. Medir, classificar e diferenciar. In: JACÓ-VILELA, A. M.; FERREIRA, A. A. L.; PORTUGAL, F. T (org.). História da psicologia: rumos e percursos. Rio de Janeiro: Nau Ed., 2006.

CAMPOS, S. M. G. ; MARTINS, R. M. L. Educação Especial: aspectos históricos e evolução conceptual. Milenium_Revista do ISPV, n. 34, p. 223-231, abril de 2008.

CHARTIER, R. A história cultural: entre práticas e representações. Rio de Janeiro:Bertrand Brasil, 1988, 244p.

COIMBRA, C. M. B; LOBO, L. F. et al. Por uma invenção ética para os direitos humanos. Psic. Clin., Rio de Janeiro, vol. 20, n. 2, p. 89-102, 2008.

CONFERÊNCIA MUNDIAL SOBRE AÇÕES E ESTRATÉGIAS PARA EDUCAÇÃO, PREVENDÃO E INTEGRAÇÃO. Declaração de Sundeberg. Torremolinos, Espanha, 07 de novembro de 1981.

CORRÊA, M. A.. M. Educação Especial, vol. 1. Rio de Janeiro: Fundação CECIERJ, 2009, 208 p. 
CRUICKSHANK, W. A educação da criança e do jovem excepcional. Porto Alegre: Globo, 1974.

DELGADO, B. Historia de la infancia. Barcelona: Ariel, 2000, p. 208-210.

DRAGO, R. Infância, educação infantil e inclusão. 2005, 187p. Tese (Doutorado em Educação) - Departamento de Educação, Pontifícia Universidade Católica do Rio de Janeiro, Rio de Janeiro, 2005.

FALCON, F. J. C. História Cultural e História da Educação. Revista Brasileira de Educação, vol. 11, n. 32, mai/ago 2006, p. 328-375.

FEARON, R. E. Serviços comunitários para a criança incomum. In: ROCEK, J. (coord.). A criança excepcional. São Paulo: IBRASA, 1968, p. 191-209.

FERNANDES. E. M.; SILVA, D. B. Inclusão da pessoa com deficiência intelectual no mundo do trabalho a partir do paradigma de suporte. Projeto de Iniciação Científica. PIBIC/UERJ, 2007.

FERREIRA, W. B. Educação inclusiva: será que sou a favor ou contra uma escola de qualidade para todos???. Inclusão - Revista da Educação Especial, Out/2005, Brasília, vol. 1, n. 1, p. 40-46.

FREITAS, G. M. A construção de um projeto de educação bilíngüe para surdos no colégio de aplicação INES na década de 1990: o início de uma nova história? Dissertação (Mestrado em Educação) - Faculdade de Educação, UFRJ, Rio de Janeiro, 2012.

FRIGOTTO, G.; CIAVATTA, M. Educação básica no Brasil na década de 1990: subordinação ativa e consentida à lógica do mercado. Educ. Soc., Campinas, vol. 24, n. 82, p. 93-130, abril 2003.

FUNDAÇÃO DE APOIO À ESCOLA TÉCNICA. Regimento escolar da educação básica/técnica da rede Faetec. Rio de Janeiro, 2008, 61p.

FUNDAÇÃO MUNICIPAL DE EDUCAÇÃO. Portaria 878/2009. Reformula a Proposta Pedagógica das Unidades de Educação que constituem a Rede Municipal de Ensino de Niterói. Niterói, 2009.

GARCIA, G. Z. I.; ROCHA, L. C. Sobre o poder normativo e a inclusão da deficiência intelectual no brasil. In: MENDES, E. G., ALMEIDA, M. A., HAYASHI, M. C. (Org). Anais do III Congresso Brasileiro de Educação Especial/ IV Encontro da Associação Brasileira de Pesquisadores em Educação Especial. São Carlos: Associação Brasileira de Educação Especial, 2008, v. 1.

GLAT, R.; FERNANDES, E. M. Da educação segregada à educação inclusiva: uma breve reflexão sobre os paradigmas educacionais no contexto da educação especial brasileira. Inclusão - Revista da Educação Especial, Out/2005, Brasília, vol. 1, n. 1, p. 35-39.

GODOY, H. P. Inclusão de alunos portadores de deficiência no ensino regular paulista. São Paulo: Mackenzie, 2002, 213p. 
GONDRA, J. G. Filhos da sombra: os "engeitados" como problema da "Hygiene" no Brasil. In: FARIA FILHO, L. M. (org). A infância e sua educação - materiais, práticas e representações. Belo Horizonte: Autêntica, 2004, p. 125-142.

GROPPO, B. O comunismo na história do século XX. Lua Nova, São Paulo, 75, 2008, p. 115-141.

JACQUES, M. G. C. Identidade e trabalho: uma articulação indispensável. In: TAMOYO, A.;BORGES-ANDRADE, J. E. \& CODO, W. (Orgs.).Trabalho, organizações e cultura. São Paulo: Cooperativa de Autores Associados, s.d. p. 4147.

JANNUZZI, G. As políticas e os espaços para a criança excepcional. In: FREITAS, M. C. (org.). História social da infância no Brasil. São Paulo: Cortez, 1997, p. 183-224.

A educação do deficiente no Brasil: dos primórdios ao início do século XXI. Campinas: Autores associados, 2004, p. 137-190.

JUDT, T. Pós-guerra: uma história da Europa desde 1945. Rio de Janeiro: Objetiva, 2008.

KASSAR, M. C. M. Liberalismo, neoliberalismo e educação especial: Algumas implicações. Cad. CEDES, Campinas, vol. 19, n. 46, set. de 1998.

KOSELLECK, R. Futuro passado: contribuições à semântica dos tempos históricos. Rio de Janeiro: Editora PUC Rio, 2006, 368p.

Uma história dos conceitos: problemas teóricos e práticos. Estudos Históricos, vol. 5, n. 10, 1992, p. 134-146.

KUHN, T. S. A estrutura das revoluções científicas. São Paulo: Perspectiva, 1970, $257 \mathrm{p}$.

LANCILLOTTI, S. S. P. Deficiência e trabalho: redimensionando o singular no contexto universal. Campinas: Autores Associados, 2003, 112p.

LE GOFF, J. Enciclopédia Einaudi. Vol. 1. Lisboa: Imprensa Nacional - Casa da Moeda, 1984.

MARINHO, H. A. M. P. Estados Unidos: o contexto dos anos 1970 e as crises do petróleo. Revista História em Reflexão: Vol. 4 n. 7, jan/jun 2010.

MARQUEZAN, R. O deficiente no discurso da legislação. Campinas: Papirus, 2009, 160p.

MAZZOTA, M. J. S. Educação Especial no Brasil: história e políticas públicas. São Paulo: Cortez, 1996, 208 p.

1986, 124p.

Educação escolar: comum ou especial? São Paulo: Pioneira,

MEC/INEP. Revista Brasileira de Estudos Pedagógicos, v. 37, n. ${ }^{\circ}$ 85-86, 1962.

. Revista Brasileira de Estudos Pedagógicos, v. 39, n. ${ }^{\circ}$ 89-92, 1963.

MELO, J. J. P. A educação e o Estado Romano. Revista UDESC, vol. 7, n. 2, 2006. 
MENDES, E. G. A radicalização do debate sobre inclusão escolar no Brasil. Revista Brasileira de Educação, v. 11, n. 33, set./dez. 2006.

MIRANDA, A. A. B. História, Deficiência e Educação Especial. Revista HISTEDBR On-line, p. 1-7, 2004.

MUNIZ, Eray Proença. Conceito de deficiência mental no século XX: construção e a (dês)construção do conceito com ênfase patológica. In: MENDES, E. G., ALMEIDA, M. A., HAYASHI, M. C. (Org). Anais do III Congresso Brasileiro de Educação Especial/ IV Encontro da Associação Brasileira de Pesquisadores em Educação Especial. São Carlos: Associação Brasileira de Educação Especial, 2008, v. 1.

NAGLE, J. Educação e sociedade na Primeira República. São Paulo: EPU/EDUSP, 1974 p. 97-124.

OLIVEIRA, E. M. Manifesto do Partido Comunista: programa da Revolução Proletária. Lutas Sociais, São Paulo, vol. 4, 2008, p. 27-32.

OLIVEIRA, M. C.; REIS, L. M. Inclusão profissional de pessoas com deficiência: o caso do instituto Ester Assumpção. In: Ações inclusivas de sucesso - coletâneas de textos do III Seminário Internacional Sociedade Inclusiva. Belo Horizonte: PUC Minas, 2004.

OMOTE, S. Normalização, integração, inclusão... Ponto de vista, vol. 1, n. 1, jul./dez. 1999.

OMS (Organização Mundial de Saúde). Classificação internacional das deficiências, incapacidades e desvantagens (handicaps). Lisboa: Ministério do Emprego e Seguridade Social. Secretaria Nacional de Reabilitação, 1989.

ONU. Assembleia Geral das Nações Unidas, 1975. Declaração dos Direitos das Pessoas Deficientes, 09 de dezembro de 1975.

ONU. Assembleia Geral das Nações Unidas, 1982. Programa de Ação Mundial de Ação Relativo à Pessoa com Deficiência, 3 de dezembro de 1982.

ONU. Assembleia Geral das Nações Unidas, 1993. Normas para Equiparação de Oportunidades para Pessoas com Deficiência, 20 de dezembro de 1993.

PEREIRA, O. S. Integração do excepcional na força do trabalho. Brasília: Departamento de documentação e divulgação, 1977, 170p.

et al. Educação especial: atuais desafios. Rio de Janeiro: Interamericana, 1980, p. 1-24.

PATTO, M. H. .S. A produção do fracasso escolar: histórias de submissão e rebeldia. São Paulo: Casa do psicólogo, 1999, 458p.

PESSOTTI, I. Deficiência mental: da superstição à ciência. São Paulo: T. A. Queiroz, 1984, 206p.

PETRÓPOLIS. Carta Regimento da Rede de Ensino. Secretaria de Educação. Petrópolis, 2008. 
PLATTOR, S. D.; PLATTOR, E. E. Educação dos pais de crianças excepcionais. In: ROCEK, J. (coord.). A criança excepcional. São Paulo: IBRASA, 1968, p. 210-226.

RAMOS, L. M. P. C. Educação das classes populares: o que mudou nas últimas décadas. Teias, Rio de Janeiro, ano 2, n. ${ }^{\circ}$ 3, p. 47-56, jan/jun 2001.

RAUPP, F. M.; BEUREN, I. M. Metodologia da pesquisa aplicável às Ciências Sociais. Disponível no endereço eletrônico http://www.geocities.ws/cienciascontabeisfecea/estagio/Cap_3_Como_Elaborar.p df no dia 03 de outubro de 2011.

ROCEK, J. (coord.). A criança excepcional. São Paulo: IBRASA, 1968, 283p.

RODRIGUES, I. E. A inclusão das pessoas com necessidades educacionais especiais no processo educativo escolar: uma experiência inversa. 2010. 196 p. Tese (Doutorado em Educação) - Departamento de Educação, Pontifícia Universidade Católica do Rio de Janeiro, Rio de Janeiro, 2010.

RODRIGUES, D. S; FRANÇA, M. P. S. G. S. A. Uso do documento em pesquisa sócio-histórica. In: MARCONDES, M. I.; TEIXEIRA, E. et al (org). Metodologias e técnicas de pesquisa em educação. Belém: EDUEPA, 2010, p. 55-74.

SANCHES, I.; TEODORO, A. Da integração à inclusão escolar: cruzando perspectivas e conceitos. Revista Lusófona de Educação, 2006, 8, p. 63-83.

SANCHÉZ, P. A. A educação inclusiva: um meio para construir escolas pra todos no século XXI. Inclusão - Revista da Educação Especial, Out/2005, Brasília, vol. 1, n. 1, p. 7-18.

SANTOS, M. P. Educação inclusiva: redefinindo a Educação Especial. Ponto de Vista, Florianópolis, n. 3/4, p. 103-118, 2002.

SASSAKI, R. A Inclusão: o paradigma do século XXI. Inclusão - Revista da Educação Especial, Out/2005, Brasília, vol. 1, n. 1, p. 19-23.

SÁ-SILVA, J. R; ALMEIDA, C. D. et al. Pesquisa documental: pistas teóricas e metodológicas. Revista Brasileira de História e Ciências Sociais, n. 1, julho de 2009 , p. $1-15$.

SECRETARIA MUNICIPAL DE EDUCAÇÃO. Resolução n. ${ }^{o} 1074$ de 14 de abril de 2010. Dispõe sobre o Regimento Escolar Básico do Ensino Fundamental na Rede Pública do Município do Rio de Janeiro. Rio de Janeiro, 2010.

SECRETARIA MUNICIPAL DE EDUCAÇÃO. Plano Municipal de Educação de Petrópolis. Petrópolis, 2008.

SEESP/ MEC. Educação inclusiva: v. 1: a fundamentação filosófica. Brasília: Ministério da Educação, Secretaria de Educação Especial, 2004, 28p.

SEESP/ MEC. Política nacional de Educação Especial na Perspectiva da Educação Inclusiva. Brasília: Ministério da Educação Secretaria de Educação Especial, 2007. 
SECRETARIA MUNICIPAL DE EDUCAÇÃO. Resolução CME n. ${ }^{\circ} 1$ de 11 de maio de 2011. Aprova o Regimento Escolar Comum das Escolas que compõem a Rede Municipal de Ensino de Mesquita. Mesquita, 2011.

SEVERINO, F. E. S.; BASSALOBRE, J. N. A dinâmica da cidade e a educação em tempos neoliberais. Revista Múltiplas Leituras, v. 4, 1, 2011, p. 85-97.

SILVA, D. B.; FERNANDES, E. M. A inclusão no mundo do trabalho e o paradigma de apoio da Associação Americana de Deficiência Intelectual. In: CHACON, M.C. M. (Org.) Qualidade de vida para pessoas com necessidades especiais - coletânea de textos da IX Jornada de Educação Especial. Marília: FFC/Unesp, 2008. CD-ROM.

SILVA, L. M. A negação da diferença: um estudo sobre as interações de alunos com deficiência visual na escola pública. 2004. 352 p. Tese (Doutorado em Educação) - Departamento de Educação, Pontifícia Universidade Católica de São Paulo, São Paulo, 2004.

THOMPSON, J. B. Ideologia e cultura moderna: teoria social crítica na era dos meios de comunicação de massa. Petrópolis, RJ: Vozes, 1995, 427p.

TONINI, A.; COSTAS, F. A. T. Escola Inclusiva: o desvelar de um espaço multifacetado. Revista do Centro de Educação, n. ${ }^{\circ}$ 26, 2005.

UNESCO, Ministério da Educação e Ciência da Espanha,1994. Declaração de Salamanca e enquadramento da ação na área das necessidades educativas especiais. Salamanca, Espanha, 7 a 10 de junho de 1994.

VEIGA-NETO, A.; LOPES, M. C. Inclusão e governamentabilidade. Educ. Soc., Campinas, vol. 28, n. 100 - Especial, p. 947-963, out. 2007.

VELOSO, F. A.; VILLELA, A. et al. Determinantes do "milagre" econômico brasileiro (1968-1973): uma análise empírica. Revista Brasileira de Economia, vol. 62, n. $^{\circ} 2$, abr./jun. 2008.

WCEFA - CONFERÊNCIA MUNDIAL DE EDUCAÇÃO PARA TODOS. Declaração mundial sobre educação para todos e Plano de ação para satisfazer as necessidades básicas de aprendizagem. Jomtien, Tailândia: março de 1990.

\section{Documentos consultados online}

http://michaelis.uol.com.br/moderno/portugues/index.php?lingua=portuguesportugues\&palavra=igualdade

- Acessado no dia 24 de abril de 2012

http://www.educabrasil.com.br/eb/dic/dicionario.asp?id=111

- Acessado no dia 02 de junho de 2012

http://www.thefreedictionary.com/laissez-faire

- Acessado no dia 06 de outubro de 2012

http://www.rio.rj.gov.br/web/sme/exibeconteudo?article-id=96318

- Acessado no dia 29 de janeiro de 2013 
http://www.faetec.rj.gov.br/ouvidoria/images/regimento_escolar_basica_tecnica_f aetec.pdf

- Acessado no dia 29 de janeiro de 2013 